\title{
JOGANDO COM A QUÍMICA DAS DROGAS
}

O papel do professor de Química na prevenção ao consumo de drogas entre adolescentes

Maria da Conceição Tavares Cavalcanti Liberato
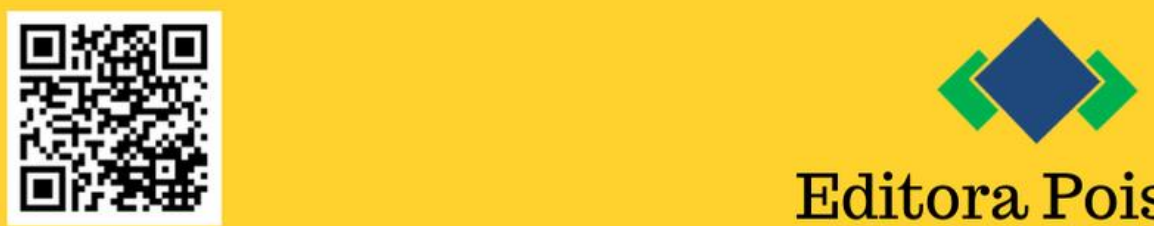

Editora Poisson 
Maria da Conceição Tavares Cavalcanti Liberato

\section{Jogando com a Química das Drogas O papel do professor de química na prevenção ao consumo de drogas entre adolescentes}

1․ Edição

Belo Horizonte

Poisson

2020 


\section{Editor Chefe: Dr. Darly Fernando Andrade}

\section{Conselho Editorial}

Dr. Antônio Artur de Souza - Universidade Federal de Minas Gerais

Ms. Davilson Eduardo Andrade

Dra. Elizângela de Jesus Oliveira - Universidade Federal do Amazonas

Msc. Fabiane dos Santos

Dr. José Eduardo Ferreira Lopes - Universidade Federal de Uberlândia

Dr. Otaviano Francisco Neves - Pontifícia Universidade Católica de Minas Gerais

Dr. Luiz Cláudio de Lima - Universidade FUMEC

Dr. Nelson Ferreira Filho - Faculdades Kennedy

Ms. Valdiney Alves de Oliveira - Universidade Federal de Uberlândia

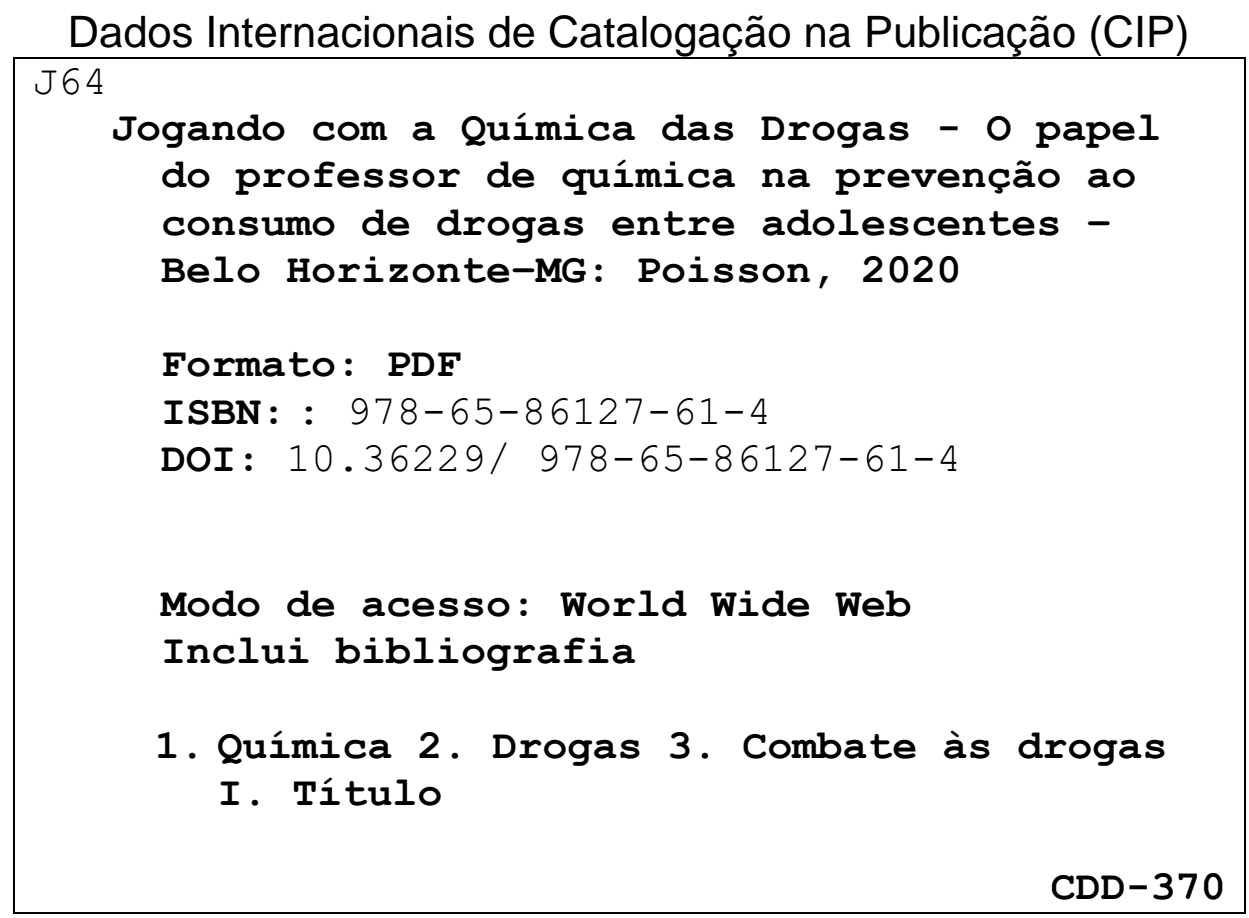

O conteúdo dos artigos e seus dados em sua forma, correção e confiabilidade são de responsabilidade exclusiva dos seus respectivos autores

$\underline{\text { www.poisson.com.br }}$

$\underline{\text { contato@poisson.com.br }}$ 


\section{SOBRE A AUTORA}

\section{Maria da Conceição Tavares Cavalcanti Liberato}

Graduada em Química Industrial pela Universidade Federal do Ceará (UFC), Especialista em Química Orgânica pela Universidade Federal do Rio de Janeiro (UFRJ), Mestre em Tecnologia de Alimentos pela Universidade Federal do Ceará (UFC), Doutora em Biotecnologia pela Rede Nordeste de Biotecnologia (RENORBIO), Professora Associada com Dedicação Exclusiva do Curso de Licenciatura em Química da Universidade Estadual do Ceará (UECE) e Professora colaboradora do Mestrado em Recursos Naturais (MARENA) da Universidade Estadual do Ceará (UECE).

\section{INFORMAÇÕES SOBRE OS PARTICIPANTES DO PROJETO}

\section{Álvaro Ventorini Vasconcelos}

Aluno do curso de Licenciatura em Química da Universidade Estadual do Ceará - UECE

\section{Amanda Batista Nascimento}

Licenciada em Química pela Universidade Estadual do Ceará - UECE

\section{Antônio Carlos Ferreira de Souza Filho}

Licenciado em Química pela Universidade Estadual do Ceará - UECE

\section{Dayana Calixto Braga}

Licenciada em Química pela Universidade Estadual do Ceará - UECE

\section{Dayanne Cipriano Costa da Silva}

Aluna do Curso de Licenciatura em Química da Universidade Estadual do Ceará - UECE

\section{Érica C. Sousa}

Licenciada em Química pela Universidade Estadual do Ceará - UECE

\section{Francinildo da Silva Brito}

Aluno do Curso de Licenciatura em Química da Universidade Estadual do Ceará - UECE

\section{Geovana Costa Aguiar}

Aluna do Curso de Licenciatura em Química da Universidade Estadual do Ceará - UECE

\section{Giovanni B. S. Maia (*)}

Licenciado em Química pela Universidade Estadual do Ceará - UECE

\section{Ítalo Ramon Rocha Muniz}

Licenciado em Química pela Universidade Estadual do Ceará- UECE

\section{Ivana Carneiro Romão}

Aluna do Curso de Licenciatura em Química da Universidade Estadual do Ceará - UECE

José Amilcar M. Araújo Neto

Licenciado em Química pela Universidade Estadual do Ceará- UECE 
Kamila de Lima Barbosa

Licenciada em Química pela Universidade Estadual do Ceará - UECE Kananda Lara Santos Sales

Licenciada em Química pelaUniversidade Estadual do Ceará - UECE Kessia Oliveira Targino

Licenciada em Química pela Universidade Estadual do Ceará- UECE Liara A. B. Pessoa

Licenciada em Química pela Universidade Estadual do Ceará- UECE Luana C. Silva

Licenciada em Química pela Universidade Estadual do Ceará- UECE

\section{Lucas Lima Bezerra}

Licenciado em Química pela Universidade Estadual do Ceará - UECE

\section{Luziane Rocha da Silva}

Licenciada em Química pela Universidade Estadual do Ceará- UECE

\section{Marcos Antônio Furtado de Carvalho Filho}

Licenciado em Química pela Universidade Estadual do Ceará- UECE

\section{Marina Maciel de Oliveira Silva}

Licenciada em Química pela Universidade Estadual do Ceará- UECE

\section{Micaelle Ribeiro dos Santos Gomes}

Licenciada em Química pela Universidade Estadual do Ceará- UECE

\section{Paulo Roberto Santos de Lima}

Licenciado em Química pela Universidade Estadual do Ceará- UECE

Priscila Bezerra Falcão

Licenciada em Química pela Universidade Estadual do Ceará- UECE

\section{Renata Almeida Farias}

Licenciada em Química pela Universidade Estadual do Ceará- UECE Sarah Geysa de Oliveira Ribeiro

Alunado Curso de Licenciatura em Química da Universidade Estadual do Ceará - UECE Sofia P. Guillén (*)

Licenciada em Química pela Universidade Estadual do Ceará- UECE

Suzanne Alves Cordeiro

Licenciada em Química pela Universidade Estadual do Ceará- UECE 


\section{Valdiana Gomes Cavalcante}

Licenciada em Química pela Universidade Estadual do Ceará - UECE Vanessa Cristina Silva Vasconcelos

Licenciada em Química pela Universidade Estadual do Ceará- UECE Verônica Bezerra Machado

Licenciada em Química pela Universidade Estadual do Ceará- UECE Victor Luís F. Lima

Licenciado em Química pela Universidade Estadual do Ceará- UECE Wivian S. Mesquita

Licenciada em Química pela Universidade Estadual do Ceará- UECE 


\section{DEDICATÓRIA}

Este livro, resultado de um trabalho conjunto, é dedicado a todos os alunos e ex-alunos do Curso de Licenciatura em Química da Universidade Estadual do Ceará, que dentro do Grupo de Estudos sobre Drogas de Abuso associaram-se à ideia de trabalhar a Química das Drogas através da ludicidade, tratando assim de um assunto que hoje é problema a ser urgentemente resolvido em nossa sociedade.

\section{AGRADECIMENTOS}

A todos os alunos participantes deste grupo que colaboraram para a criação desse livro. Agradeço de forma muito especial ao apoio da Pró-Reitoria de Extensão - PROEX da Universidade Estadual do Ceará - UECE - que tornou possível a realização desse trabalho.

Profa. Dra. Maria da Conceição Tavares Cavalcanti Liberato 


\section{APRESENTAÇÃO}

O ensino de Química tem por fim proporcionar aos alunos o conhecimento da composição e da estrutura íntima dos corpos, das propriedades que delas decorrem e das leis que regem as suas transformações, orientando-o por um tirocínio lógico e científico de valor educativo e coordenando-o pelo interesse imediato da utilidade, e com as aplicações da vida cotidiana (SENNA, 1939).

As Orientações Curriculares para o Ensino Médio (BRASIL, 2006) indicam que "o mundo atual exige que o estudante se posicione, julgue, tome decisões, e seja responsabilizado por isso. Essas são capacidades mentais construídas nas interações sociais vivenciadas na escola, em situações complexas que exigem novas formas de participação. Para isso, não servem componentes curriculares desenvolvidos com base em treinamento para respostas padrão. Um bom projeto pedagógico escolar adequado não é avaliado pelo número de exercícios propostos e resolvidos, mas pela qualidade das situações propostas, em que estudantes e professores, em interação, produzem conhecimentos contextualizados e inter-relacionados".

Nos dias atuais, o consumo desenfreado de drogas de abuso iniciando-se cada vez mais precocemente tem deixado educadores perplexos diante do quadro apresentado. Muitas vezes a escola tem sido palco de uso de drogas refletindo-se em cenas de violência, entre os alunos e mesmo dos alunos para com os professores. A introdução do assunto em sala de aula pode fazer alguma diferença.

A disciplina de Química muitas vezes não parece interessante aos olhos dos alunos, pois aos olhos dos mesmos, parece fugir de seu cotidiano tornando-se difícil apreender tantos conceitos. Especialistas da área de Educação defendem que o crack precisa ser debatido nas escolas. No entanto, a maioria dos docentes não está preparada para lidar com a questão das drogas nas escolas. A preparação de professores, que têm contato diário com jovens, é essencial para um trabalho preventivo. A criação de jogos, cujo aspecto lúdico aliado ao conteúdo da disciplina possibilita o uso em sala de aula durante exposições referentes aos temas como estruturas e grupos funcionais. Chamando a atenção para as drogas de abuso e suas consequências, o professor de Química pode vir a atuar como coadjuvante nessa exposição de cada droga e de seus efeitos.

Experiências realizadas em eventos organizados pelo Curso de Licenciatura em Química da Universidade Estadual do Ceará têm chamado a atenção pelo interesse 
demonstrado por professores e alunos de instituições públicas e privadas da cidade de Fortaleza. Após esses eventos foram aplicados questionários sobre a parte relacionada à matéria em si e às drogas abordadas. Pela avaliação obtida foi possível verificar que entre alunos do Ensino Fundamental das Escolas de Fortaleza 43\% já se iniciaram no consumo de drogas através do álcool.

Diante desse quadro, torna-se imperativo a capacitação do professor de Química que em suas aulas pode participar da ação de combate às drogas de abuso por parte de crianças e jovens. 


\section{SUMÁRIO}

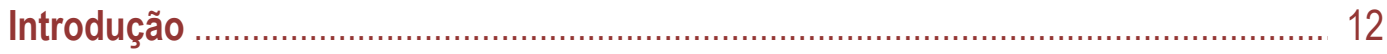

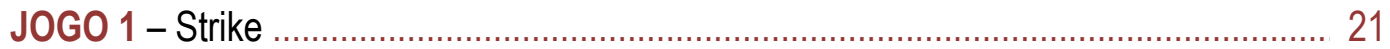

Renata Almeida Farias

DOI: 10.36229/978-65-86127-61-4.CAP.01

JOGO 2 - Drogas: Conhecimento em ação

Marina Maciel de Oliveira Silva, Wivian de Sousa Mesquita, Victor Luís Ferreira Lima, José Amilcar Mendes Araújo Neto, Dayana Calixto Braga, Luana Carvalho da Silva, Sofia P. Guillén, Giovanni B. S. Maia, Maria da Conceição Tavares Cavalcanti Liberato

DOI: 10.36229/978-65-86127-61-4.CAP.02

JOGO 3 - Ajude-me!

Valdiana Gomes Cavalcante

DOI: 10.36229/978-65-86127-61-4.CAP.03

JOGO 4 - Você conhece as drogas de abuso?

Ivana Carneiro Romão; Késsia Oliveira Targino

DOI: 10.36229/978-65-86127-61-4.CAP.04

JOGO 5 - Jogando com a Química das drogas

Kessia Oliveira Targino; Ivana Carneiro Romão; Érica Carneiro de Sousa; Liara Amanda Barbosa Pessoa; Renata Almeida Farias

DOI: 10.36229/978-65-86127-61-4.CAP.05

JOGO 6 - Roleta Química

Kamila de Lima Barbosa; Kananda Lara Santos Sales; Amanda Batista Nascimento;

Kessia Oliveira Targino; Renata Almeida Farias; Lucas Lima Bezerra

DOI: 10.36229/978-65-86127-61-4.CAP.06

JOGO 7 - Jogando se aprende a Química das drogas

Kamila de Lima Barbosa; Paulo Roberto Santos de Lima, Álvaro Ventorini Vasconcelos,

Geovana Costa Aguiar

DOI: 10.36229/978-65-86127-61-4.CAP.07

JOGO 8 - É droga mesmo!

Ítalo Ramon Rocha Muniz; Francinildo da Silva Brito

DOI: 10.36229/978-65-86127-61-4.CAP.08

JOGO 9 - Uma aula de Química diferente 40

Micaelle Ribeiro dos Santos Gomes; Renata Almeida Farias; Ítalo Ramon Rocha Muniz

DOI: 10.36229/978-65-86127-61-4.CAP.09 


\section{SUMÁRIO}

JOGO 10 - Embaralho das drogas.

Marina Maciel de Oliveira Silva

DOI: $10.36229 / 978-65-86127-61-4 . C A P .10$

JOGO 11 - Brincando e aprendendo sobre drogas de abuso.

47

Marcos Antônio Furtado de Carvalho Filho; Marina Maciel de Oliveira Silva; Antônio

Carlos Ferreira de Souza Filho; Priscila Bezerra Falcão, Suzanne Alves Cordeiro;

Verônica Bezerra Machado

DOI: 10.36229/978-65-86127-61-4.CAP.11

JOGO 12 - Atos e Consequências.

Luziane Rocha da Silva; Vanessa Cristina Silva Vasconcelos

DOI: 10.36229/978-65-86127-61-4.CAP.12

JOGO 13 - Drogas Trívia.

Kessia Oliveira Targino; Renata Almeida Farias

DOI: 10.36229/978-65-86127-61-4.CAP.13

JOGO 14 - Sou dependente químico?

Valdiana Gomes Cavalcante

DOI: 10.36229/978-65-86127-61-4.CAP.14

JOGO 15 - De cara com as drogas!.

Sarah Geysa de Oliveira Ribeiro; Dayanne Cipriano Costa da Silva; Álvaro Ventorini

Vasconcelos; Geovana Costa Aguiar

DOI: 10.36229/978-65-86127-61-4.CAP.15

Referências 


\section{INTRODUÇÃo}

\section{HISTÓRICO}

A palavra "droga" refere-se a uma substância química tomada de forma deliberada para obter efeitos desejados. Algumas drogas são usadas do ponto de vista médico para tratar doenças, enquanto outras são tomadas devido a seus efeitos prazerosos. Ambos os usos têm origens antigas.

Os primeiros humanos eram caçadores-coletores: tinham que aprender quais dentre as diversas plantas em seu ambiente eram boas para comer e quais eram venenosas. Por tentativa e erro, eles também acumularam gradualmente conhecimento sobre quais plantas ou outros materiais naturais podiam aliviar a dor ou tratar os sintomas de doenças. Porém, o consumo de plantas medicinais não é restrito a humanos. Estudos sobre o comportamento de chimpanzés revelaram que animais doentes às vezes selecionam plantas que normalmente não fazem parte de sua dieta apenas pelos efeitos antiparasitários.

Entre os primeiros registros escritos sobre medicamentos fitoterápicos estão os da China antiga, sendo o primeiro livro publicado durante a dinastia Han, no século II. Ele listava 365 remédios fitoterápicos tornando-se base importante para o desenvolvimento da medicina chinesa. 0 livro foi revisado várias vezes sendo a mais relevante a preparada por Li Shin Chen, durante a dinastia Ming, no século XVI. Constava de 52 volumes e listava 1.898 remédios que tinham como origem plantas, animais e minerais.

Medicamentos fitoterápicos continuam sendo importantes na medicina chinesa moderna, e muitas substâncias ativas dessas fontes foram introduzidas na medicina ocidental. Farmacopeias fitoterápicas sistematizadas também surgiram em outras culturas como, por exemplo, na Índia, na Grécia, na Roma Antiga, no mundo Árabe e na Europa da era medieval. A Renascença viu o desenvolvimento da era da medicina científica. Porém a maior parte da prática da medicina continuou a apoiar-se em remédios tradicionais. Os principais remédios no século XVIII eram o álcool e o ópio.

\subsection{AS DROGAS RECREATIVAS}

0 uso recreativo de drogas faz parte do comportamento humano há milhares de anos. Provavelmente o álcool foi a primeira dessas drogas já que é facilmente obtido por meio de frutas e leveduras silvestres comuns na maioria dos lugares do mundo. Facilmente descobriu-se como controlar o processo de fermentação para produzir vinhos e cervejas. A produção de bebidas alcoólicas em sua grande variedade transformou-se em uma grande indústria, e seu consumo, excetuando-se entre os países islâmicos, expande-se por todo o mundo.

0 fumo de tabaco é o segundo meio mais popular de uso de drogas recreativas no mundo ocidental atualmente. A planta de tabaco Nicotiana rustica é nativa da América do Norte, e fumar as folhas secas era um costume de muitas tribos de índios americanos. 0 cigarro como um recurso conveniente e eficaz para o fumo não era comum até o século XX. O ensino de Química tem por fim proporcionar aos alunos o conhecimento da composição e da estrutura íntima dos corpos, das propriedades que delas decorrem e das leis que que regem as suas transformações, orientando-o por um tirocínio lógico e científico de valor educativo e coordenando-o pelo interesse imediato da utilidade, e com as aplicações da vida cotidiana (SENNA, 1939).

Apenas a partir de 1950 os riscos do fumo do tabaco começaram a surgir. Embora o ingrediente ativo no tabaco, a nicotina, seja relativamente atóxico, a inalação da 
fumaça das folhas do tabaco é nociva. Porque contém várias substâncias químicas que podem desencadear o câncer, particularmente o câncer de pulmão.

Na Índia e no mundo árabe, o fumo das folhas queimadas de outra planta, a Cannabis sativa, foi muito praticado durante milhares de anos. As folhas secas (maconha) e os botões da planta fêmea, mais potentes (sinsemilla), ou a resina de cânhamo podem ser fumadas. 0 uso do cânhamo como droga recreativa era desconhecida no Ocidente até meados do século XX, quando se tornou popular com as gerações beat e hippie nas décadas de 60 e 70. Hoje é a terceira droga recreativa mais usada após o álcool e o tabaco.

A folha de coca não era queimada, mas mascada pelos índios peruanos, e considerada pelos incas como um símbolo de divindade. Quando o ingrediente ativo cocaína foi isolado como substância química pura a droga tornou-se popular por suas propriedades medicinais. Um dos usos medicinais recomendados era no tratamento do vício em ópio: um problema que começava a surgir no final do século XIX.

O ópio, resina seca extraída da papoula, é outro exemplo de medicamento antigo que também serviu como droga recreativa. É um dos analgésicos eficazes mais antigos. 0 ópio é conhecido desde a pré-história. Os sumérios chamavam-no "planta da alegria". Egípcios, gregos, romanos e islâmicos usaram-no. Os árabes introduziram o ópio na Î́ndia e depois na China. Os chineses usaram o ópio para controlar a diarreia. No século XIX havia milhões de chineses viciados em ópio.

Os narcóticos foram introduzidos nos Estados Unidos no século 19 pelos trabalhadores chineses que comiam e fumavam ópio. Paracelso reintroduziu o uso médico do ópio na Europa Ocidental. William Collen em 1808, admitiu que o ópio suspendia o fluxo de mensagens dos nervos para o encéfalo e vice-versa, abolindo a dor. Ele observou que embora fosse sedativo em algumas pessoas poderia exibir efeito excitante. Outros acreditavam que o ópio atuava como excitante sempre. A planta do ópio só foi introduzida no México, na América do Sul e demais países da América Central a partir da Segunda Guerra Mundial.

O ópio e mais tarde o composto puro morfina, serviu de base para centenas de medicamentos. Seu consumo aumentou muito na última parte do século XIX, e a invenção da seringa hipodérmica, em 1850, permitiu que a morfina e seu derivado sintético mais poderoso, a heroína, fossem diretamente administrados no sangue.

$\mathrm{O}$ século XX viu surgirem drogas totalmente sintéticas que alteram a consciência. As primeiras foram as anfetaminas. Inicialmente eram administradas em gotas ou via inalador para ajudar a aliviar a congestão nasal. Formas mais potentes e novas formas de administração de anfetaminas como a metanfetamína continuam a ser utilizadas.

A descoberta do LSD acompanhou a redescoberta de outros alucinógenos derivados de plantas como a mescalina do cacto mexicano peiote, a psilocibina do "cogumelo mágico" mexicano teonnnncatl. No final do século XX juntou-se a esses alucinógenos o ecstasy, um composto que combina as propriedades estimulantes da d-anfetamina com as propriedades moderadamente alucinógenas, como as da mescalina.

\subsection{ABORDAGEM DO ASSUNTO DROGAS NA SALA DE AULA}

0 uso de drogas segue em curva ascendente entre jovens brasileiros de todas as classes sociais. Uma forma de medir esse avanço está no fato de que há dez anos duzentos mil brasileiros haviam tido contato com o crack. Em uma década esse número saltou para oitocentos mil, segundo pesquisadores.

0 assunto "drogas" precisa ser debatido em sala de aula. Infelizmente os docentes não estão preparados para lidar com a questão. É importante que o professor fale e 
estimule o diálogo e nada é mais promissor que as aulas de Química dediquem um espaço ao assunto. É importante usar atividades lúdicas no enfoque a um assunto difícil de ser abordado. Segundo Soares (2015), a atividade lúdica pode ser definida como uma ação divertida, relacionada aos jogos, seja qual for o contexto linguístico, com ou sem a presença de regras, sem considerar o objeto envolto nessa ação. É uma ação que gera um mínimo de divertimento.

Com o objetivo de atuar nessa cruzada contra as drogas, que vêm destruindo vidas adolescentes, alunos do Curso de Licenciatura em Química da Universidade Estadual do Ceará, e participantes do Grupo de Estudos sobre Drogas de Abuso, através de projeto vinculado à Pró-Reitoria de Extensão (PROEX) criaram jogos que abordam a Química das drogas de abuso nas aulas para alunos do Ensino Fundamental e Médio.

Na linguagem usual chama-se "droga" a qualquer substância química que após sua administração, interfere no funcionamento dos organismos vivos, podendo-se considerar uma simples célula como um organismo inteiro. Entende-se como funcionamento o conjunto de reações bioquímicas e fisiológicas que mantêm a vida de todos os organismos. Assim as drogas entrariam nessas reações bioquímicas e "enganariam" os processos orgânicos e, através de ligações químicas com os diversos componentes das células ou tecidos, substituiriam ou alterariam as funções preexistentes das moléculas endógenas.

Outra questão é que a cada droga corresponde um dado efeito biológico. De tal maneira que esse efeito é tão mais intenso quanto maior for a quantidade de droga disponível para atuar em diferentes sistemas biológicos, até um limite compatível com o funcionamento desse sistema.

Em consequência efeitos tóxicos surgem do uso de quantidades excessivas de drogas que então podem ser consideradas como venenos. Assim pode-se concluir que toda droga é um veneno em potencial, dependendo da quantidade administrada. No entanto é importante ressaltar que existem drogas utilizadas para tratar doenças e, nesse caso, denominam-se fármacos.

0 modo através do qual cada droga produz seus efeitos no corpo segue princípios gerais. Após o seu consumo as drogas precisam ultrapassar sucessivamente algumas barreiras corporais para finalmente chegar ao local onde produzem seus efeitos. 0 cérebro é o principal local de ação para as drogas usadas em excesso. Os efeitos indesejáveis que ocorrem em outros lugares além do cérebro são chamados de efeitos colaterais.

\section{METABOLISMO DAS DROGAS}

0 metabolismo bioquímico das drogas se constitui num processo que leva à alteração da molécula original, também denominada molécula parental. Essa molécula é transformada normalmente com a participação de enzimas dos tecidos em um ou vários compostos, denominados metabólitos. Anteriormente, acreditava-se que o metabolismo das drogas constituía-se em um mecanismo geral de "desintoxicação" utilizado pelo organismo para se livrar de compostos danosos, endógenos ou exógenos.

No entanto, a descoberta de metabólitos com atividade igual ou maior do que a do composto parental, como a morfina, que é produzida pelo metabolismo hepático a partir do metabolismo da codeína (droga anteriormente muito usada como antitussígeno), levou ao conceito atual de metabolismo de drogas ou biotransformação.

A biotransformação de drogas pode ocorrer, em maior ou menor grau, em praticamente todas as células do organismo. O intestino, os pulmões, os rins são importantes órgãos metabolizadores de drogas. Entretanto, o principal órgão 
metabolizador de drogas no organismo é o fígado. Entre outros efeitos, esse metabolismo hepático geralmente aumenta a hidrofilicidade das drogas e, portanto, sua capacidade de ser excretada.

Em geral, os metabólitos que são produzidos são menos ativos farmacologicamente do que o substrato droga: no entanto, algumas pró-drogas inativas são convertidas em suas formas ativas como consequência do processamento hepático. Os sistemas hepáticos de metabolização de drogas precisam atuar numa infinidade de moléculas; isto é alcançado pelas enzimas envolvidas que têm baixa especificidade pelo substrato.

\subsection{ALTERAÇÃO DA SENSAÇÃO DE DOR}

Analgésicos Endógenos: Existem pessoas que sofreram ferimentos graves e relatam que no momento da lesão não sentiram dor. Isso é explicado pelo fato do encéfalo, para inibir a sensação de dor, liberar neurotransmissores como endorfina, dinorfina e encefalina que atuam como Analgésicos Endógenos.

Esses neurotransmissores são liberados também quando a pessoa sente prazer após estresse. Pode-se citar como exemplos o prazer sentido após a prática de esportes radicais ou após assistir a filmes de terror. A sensação de alívio após o medo é devido à liberação desses neurotransmissores. Os receptores com os quais eles interagem são denominados receptores de opioides, porque derivados do ópio, como morfina e codeína também interagem com eles diminuindo a dor.

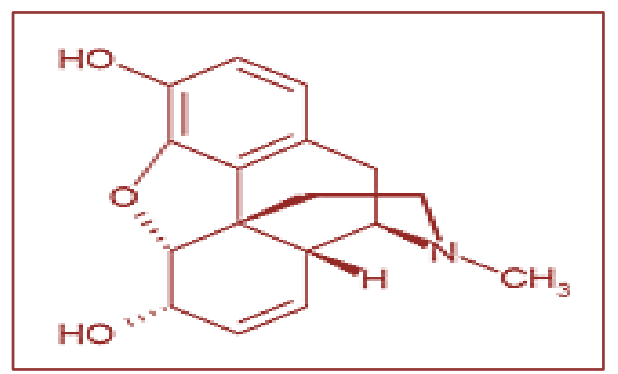

Estrutura da morfina

Analgésicos Fracos: São os chamados anti-inflamatórios não-esteroidais, que possuem estrutura química variada e exercem atividade analgésica, antipirética e antiinflamatória como, por exemplo, a Aspirina. Caso a dor não seja aliviada, pode-se usar com esses analgésicos, opioides fracos, como a codeína. Em último caso são usados opioides potentes como a morfina (câncer).

Analgésicos de Ação Geral: Opioides são os principais representantes dos analgésicos de ação geral. São substâncias naturais, semissintéticas ou sintéticas que agem tanto como agonistas, quanto como antagonistas em determinados receptores presentes no sistema nervoso, os receptores de opioides. 0 ópio é extraído da papoula e contém 25 alcaloides. Exemplos: morfina, codeína, papaverina e a heroína.

\section{DROGAS E FATORES EMOCIONAIS}

Todas as sensações possuem algo definido que estimula os receptores localizados nos órgãos dos sentidos: mecanorreceptores, nocireceptores, etc. Quais os estímulos para as sensações emocionais? É difícil responder pois, independente do tipo de emoção, 
todas elas trazem alterações fisiológicas, psicológicas e comportamentais, que são comandadas pelo Sistema Nervoso Central (SNC).

No SNC, existe o sistema límbico que é definido como o centro das emoções, sendo na verdade um conjunto de regiões. Desse sistema faz parte uma estrutura chamada amígdala, que funciona como uma espécie de botão de disparo para todas as sensações emocionais. Outra parte do encéfalo envolvida com elas é o hipotálamo. Antes do estímulo, real ou imaginário, desencadear uma sensação emocional, ele percorre vários caminhos no SNC. Os estímulos sensoriais chegam diretamente à amígdala, ou são processados e interpretados pelo cérebro, para depois atingi-la. Os neurônios da amígdala se comunicam com os do hipotálamo ativando os do sistema nervoso vegetativo, endócrino, imunitário e do motor, o que resulta nas mudanças comportamentais e fisiológicas características das sensações emocionais.

O sistema vegetativo e o endócrino controlam as alterações fisiológicas como: a sudorese, a secura da boca, a tensão no estômago, a respiração rápida, a taquicardia e as tensões musculares. Essas alterações provocadas pelas emoções são consideradas com um propósito de sobrevivência. Existem duas classes básicas de emoções: as apetitivas e as aversivas. A ativação metabólica e neural para os dois sistemas faz a pessoa ficar em estado de alerta.

\subsection{DROGAS AGONISTAS E ANTAGONISTAS}

As drogas podem ser agrupadas em duas grandes categorias: agonistas e antagonistas. As agonistas produzem efeitos e as antagonistas bloqueiam os efeitos dos hormônios e outras substâncias químicas no corpo, assim como os de outras drogas.

As drogas são mais especificamente classificadas de acordo com o tipo de efeito que é produzido ou bloqueado, tais como sedativos ou antidepressivos. Estes grupos ainda podem ser subdivididos segundo a maneira como estes efeitos são produzidos. Uma droga produz um efeito porque ela se assemelha a uma substância química encontrada no corpo, interagindo assim com as estruturas celulares, os receptores, que estavam predestinados para a substância química original. A interação entre a droga e o receptor desencadeia ou impede uma sequência de transformações bioquímicas que ao final modifica a função da célula, tecido ou órgão.

Drogas Agonistas, portanto, são substâncias que interagem com um receptor da mesma forma que a molécula natural interagiria, produzindo o mesmo efeito que ela causaria. Morfina, heroína e codeína são agonistas para os neurotransmissores de endorfinas, encefalinas e dinorfina.

Diferentes drogas usadas em excesso podem interagir com diferentes áreas do cérebro. Contudo, a maioria destas drogas produz efeitos em um sistema cerebral muito importante: o Circuito de Recompensa. A recompensa proporcionada pelas drogas nesta área do cérebro é o prazer. Uma vez que este prazer é vivenciado, ele funciona como uma das motivações para o uso contínuo da droga. O Circuito de Recompensa é muito importante para a nossa sobrevivência. Ele costuma ser ativado por comportamentos comuns como comer, por exemplo.

\subsection{CIRCUITO DE RECOMPENSA}

É o caminho final percorrido pelas drogas no cérebro. Sua função é prover uma razão ou uma recompensa como um prazer intenso, por exemplo, para realizar várias atividades. 0 circuito de recompensa interage direta e indiretamente com várias áreas e sistemas do cérebro, incluindo aquelas relacionadas à vivacidade, emoção, memória, 
motivação, movimento, equilíbrio e controle dos hormônios. Muitas destas interações têm consequências significativas. Para as que estão associadas ao prazer, o próprio prazer é lembrado como uma recompensa associada a atividade que o causou e está memória fornece motivação para tornar a vivenciar o prazer.

0 circuito de recompensa, assim como todos os circuitos no cérebro, funciona através de neurotransmissores, especialmente a dopamina. Para que uma droga usada de modo abusivo interaja com o circuito de recompensa, o único procedimento necessário para produzir uma recompensa é a ingestão da droga. Os efeitos da droga no cérebro alteram a atividade do circuito de recompensa e, assim, a recompensa (prazer, euforia, etc.) passa a ser vivenciada. Drogas, tão diferentes em seus efeitos, como a cocaína e a morfina têm demonstrado afetar o circuito de recompensa do cérebro. 0 circuito de recompensa central vai de uma área do mesencéfalo (área ventral tegumentar, AVT) até um núcleo específico no sistema límbico (nucleus accumbens, NA) de lá para áreas do córtex cerebral e núcleos basais. Os corpos celulares dos neurônios de dopamina estão localizados no AVT e os seus terminais estão no NA. Outros neurotransmissores podem modificar a quantidade de dopamina liberada no NA ou até modificar a função dos neurônios sobre os quais a dopamina é liberada. Dois outros circuitos podem estar envolvidos no sistema comum de recompensa para drogas. Em particular, os circuitos do NA para uma área de um dos núcleos basais, e do NA para uma área situada abaixo do sistema límbico. A função desses dois circuitos envolve a atividade motora e o neurotransmissor GABA (Ácido Gama Amino Butírico).

\section{FATORES ENVOLVIDOS NO ABUSO DE DROGAS}

Fatores Psicológicos representam um dos principais determinantes do abuso de drogas. Entre eles, o comportamento de busca ou procura específica de droga psicoativa em situações de impossibilidade de obtenção, como na indisponibilidade de dinheiro para a sua compra, por exemplo, caracteriza a dependência psíquica ou psicológica. Sintomas de retirada caracterizam a síndrome de abstinência, que, por sua vez, caracteriza a dependência física a drogas.

A síndrome de abstinência, dependendo do grupo de drogas psicoativas considerado, pode ser muito grave, levando, inclusive à morte do indivíduo, como no caso da dependência aos opioides. Fatores Sociais, como a dificuldade de acesso à Educação, e fatores político-conjunturais, como o desemprego crescente na população, apresentam também um peso enorme na determinação do abuso de drogas. Nesse tipo de situação, a falta de perspectiva individual e coletiva, raízes do descontentamento, gera a violência crescente em todos os níveis, em especial a violência urbana. Fatores genéticos também parecem contribuir em até $60 \%$ no caso do abuso de drogas na população.

\section{DROGAS DE ABUSO}

Esse termo refere-se a qualquer uso de drogas que venha a ferir as normas sociais ou legais vigentes em determinada época, em determinada sociedade, e engloba desde o uso de drogas lícitas, como o consumo de bebidas alcoólicas durante o trabalho, até o uso de medicamentos sem prescrição médica. As drogas de abuso são frequentemente ilegais devido aos seus efeitos colaterais, por acarretarem mudanças de comportamento e porque levam a dependência química, física e psicológica. Engloba desde o uso de drogas ilícitas como maconha, heroína etc. até o uso inadequado de drogas lícitas como o álcool e o uso de remédios. 


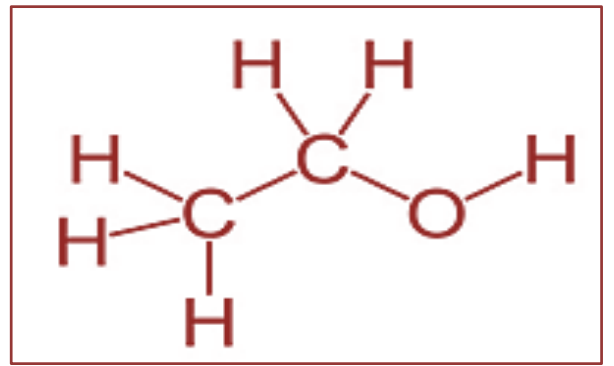

Estrutura do Etanol

Existem pelo menos cinco maneiras pelas quais as drogas conseguem entrar no organismo: por via oral, pelo contato através da pele ou olhos, por inalação, por aspiração, por injeção. 0 modo pelo qual se administra uma droga pode determinar a probabilidade de que esta desenvolva seu potencial e passe a ser usada de forma excessiva. As drogas, em geral, são ácidos ou bases fracas e, portanto, se dissociam em solução, dependendo do pH do meio em que se encontram. É importante que as drogas sejam eletrólitos fracos para que possam ser "conduzidas" pela circulação sanguínea. Mais da metade do corpo constitui-se de água facilitando muito o transporte das drogas que são eletrólitos fracos.

\subsection{AÇÃO POR VIA ORAL}

Ao tomar uma bebida alcoólica, um comprimido, um chá de cogumelo, a droga entra em no organismo por via oral. Ela passa por todo o sistema digestivo, até ser absorvida nos vasos sanguíneos das paredes do intestino. Ela deve ser resistente às enzimas salivares e aos ácidos presentes no estomago, senão será destruída. Seus efeitos são mais fracos aparecendo após 20 ou $30 \mathrm{~min}$.

\subsection{AÇÃO POR CONTATO}

Algumas drogas como o LSD, podem ser pingadas no olho ou em uma parte úmida da pele. Entram no organismo por contato, o que as faz agir mais rápido do que por via oral. As reações aparecem 5 a 10 min após o contato.

\subsection{AÇÃO POR INALAÇÃO}

Quando a droga é inalada, seus efeitos aparecem mais rápido. Cerca de 3 a 5 min. A cocaína e a heroína são utilizadas assim, sendo aspiradas pelo nariz e absorvidas pelos vasos sanguíneos das fossas nasais.

\subsection{AÇÃO POR ASPIRAÇÃO}

Algumas drogas podem ser aspiradas como, por exemplo, um cigarro normal, de maconha ou crack. A droga vaporizada entra nos pulmões e é absorvida de imediato pelos vasos sanguíneos dos alvéolos do pulmão. Daí o sangue com a droga é bombeado para o coração e segue para o cérebro. Seus efeitos aparecem após 7 a 10 seg. 


\subsection{AÇÃO POR INJEÇÃO}

As drogas injetáveis como: cocaína, morfina, heroína e outras entram diretamente na corrente sanguínea. É um meio rápido e eficaz para sua absorção. Os efeitos aparecem após 15 a $30 \mathrm{seg}$.

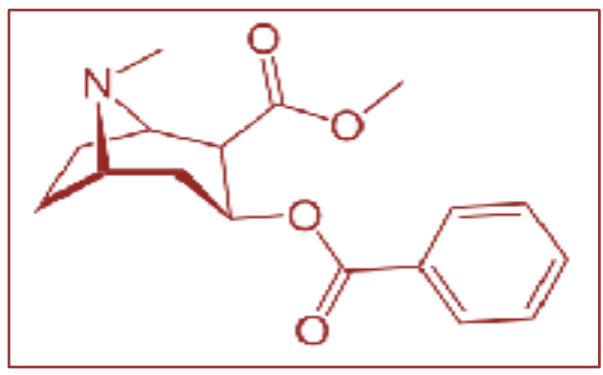

Estrutura Química da Cocaína

Muitas perguntas surgem diante das ações causadas pelas drogas. Pode-se perguntar então o que ocorre quando a droga entra no organismo? Como ela consegue chegar ao encéfalo? Como ela age no encéfalo? Em primeiro lugar ela cai na corrente sanguínea. Com o sangue, percorre todos os órgãos, fluidos e tecidos do corpo, podendo ser desprezadas, absorvidas, transformadas ou metabolizadas. Isso ocorre em 10 a 15 seg. Depois disso atinge o cérebro. Mas, como as drogas alcançam o cérebro? Como conseguem atravessar a barreira hemato-encefálica? Quais drogas atravessam essa barreira?

As drogas interagem com células através de estruturas especializadas já existentes para as funções regulares, ou seja, a superfície de um receptor. As drogas agem como os primeiros mensageiros de sinais para os receptores. A interação entre uma droga e um receptor é detectada e transmitida para as estruturas intracelulares e os processadores. 0 receptor e o processador estão frequentemente acoplados através das proteínas G. A recepção e transmissão de um sinal de um determinado receptor acoplado a uma proteína $\mathrm{G}$ poderia, por exemplo, provocar o aumento da quantidade de cálcio. Outros receptores podem usar suas respectivas proteínas G para provocar mudanças na produção do composto cAMP (Adenosina Monofosfato cíclica). O cálcio (Ca) e o cAMP funcionam como os segundos mensageiros e continuam o processo de transmissão de sinais. As reações celulares aos estímulos do receptor variam de acordo com o tipo de célula. Algumas células podem reagir aumentando ou diminuindo o número de receptores na superfície da célula. Outras modificam a produção e/ou liberação de um produto químico. Este último tipo de célula pode atuar como um sinal para outras células, em alguns casos, até mesmo a própria célula emissora pode responder ao sinal (LONGENECKER, 1998).

\section{ALTERAÇÕES ENVOLVIDAS COM DROGAS DE ABUSO}

As substâncias capazes de alterar os estados mentais podem atuar como estimulantes, depressoras e perturbadoras. A maioria das drogas interfere principalmente nas partes do encéfalo que regulam sensações emocionais, humor, sono e memória. A droga para atravessar a barreira hemato-encefálica, ou é lipossolúvel ou deve interagir com alguma molécula que a transporte para dentro do encéfalo. Geralmente as drogas de abuso possuem em sua estrutura química anéis aromáticos que 
conferem lipossolubilidade à molécula. Basicamente as moléculas podem agir de duas formas: como agonista ou antagonista.

\subsection{AGONISTA}

Interage com o receptor e ocasiona uma resposta biológica igual ao modo como o neurotransmissor ou outra molécula endógena age.

\subsection{ANTAGONISTA}

É capaz de se ligar ao receptor sem promover a resposta biológica, bloqueando a ação do agonista e/ou da molécula endógena ocasionando uma resposta inversa. As células nervosas ou neurônios comunicam-se entre si (e com outro tipo de células fora do sistema nervoso) através de neurotransmissores. A liberação de um neurotransmissor é provocada por um potencial de ação, que normalmente tem início na junção do corpo celular de um neurônio com o seu axônio e segue unidirecionalmente até a ponta do axônio ou terminal. Existem substâncias químicas de carga positiva e negativa dentro e fora das células, mas a distribuição das cargas é diferente. Esta diferença gera um sinal elétrico através da membrana celular, chamado de potencial da membrana.

Os neurotransmissores modificam o potencial da membrana através de receptores que se situam em várias partes dos neurônios. Cada neurotransmissor inverte o potencial de maneira previsível: alguns estimulam enquanto outros inibem o neurônio. Um neurônio pode sofrer a ação de mais de um neurotransmissor ao mesmo tempo. Neste caso, o potencial da membrana é a soma dos efeitos de todos os neurotransmissores envolvidos. Algumas drogas assemelham-se aos neurotransmissores. As enzimas facilitam a síntese do neurotransmissor. A ação de um neurotransmissor pode ser detida através da sua reabsorção pelo terminal e em seguida pelas vesículas, ou por sua degradação através de uma enzima. 0 cálcio causa a fusão das vesículas com a membrana da superfície do terminal do axônio. Esta fusão libera o neurotransmissor no espaço entre o terminal e o neurônio vizinho. 0 terminal do axônio permite a entrada de uma quantidade extra de cálcio através dos poros abertos. 0 neurotransmissor combina-se então com os receptores de outro neurônio. Os neurotransmissores estão armazenados em pequenas estruturas chamadas vesículas. Os neurotransmissores permanecem nestas vesículas até que ocorra um potencial de ação que alcance o terminal do axônio, fazendo com que os neurotransmissores sejam liberados.

Infelizmente, os adolescentes estão cada vez mais envolvidos com as drogas, sejam elas ilícitas ou não. A pressão da família, escola e até mesmo o vestibular, contribuem para a construção de uma situação propícia ao uso dos entorpecentes. Além do mais, as más influências assumem um papel de suma importância para o percalço.

0 tráfico de drogas é uma cadeia, partindo do produtor da droga até o usuário, sendo mantido através do ciclo da venda e compra destas. Muitas vezes, a busca incessante de manter o vício acaba gerando conflitos devido às dívidas, construindo assim, um quadro de fragilidade familiar. São inúmeros relatos de que os jovens envolvidos acabam vendendo todos os móveis para pagar a dívida e manter o vício, sendo um problema cujo deve ser combatido por toda a sociedade, desde a família, amigos, até aos órgãos de reabilitação, como, por exemplo, as casas de apoio. 


\section{Jogo \\ 01 Strike \\ Renata Almeida Farias}

\section{OBJETIVO}

O mundo das drogas é demasiado tentador para um viciado em drogas lícitas ou ilícitas tornando difícil encontrar uma saída e por diversos caminhos este mundo tentará revogar aqueles que tentam dele sair. Este jogo possui seis caminhos que irão ajudar os jogadores a se conscientizar e superar o vício das drogas ao longo da jornada. Sobreviva aos strikes causados pela abstinência e vença o jogo.

QUANTIDADE DE JOGADORES: 2 a 6 jogadores

\section{TABULEIRO}

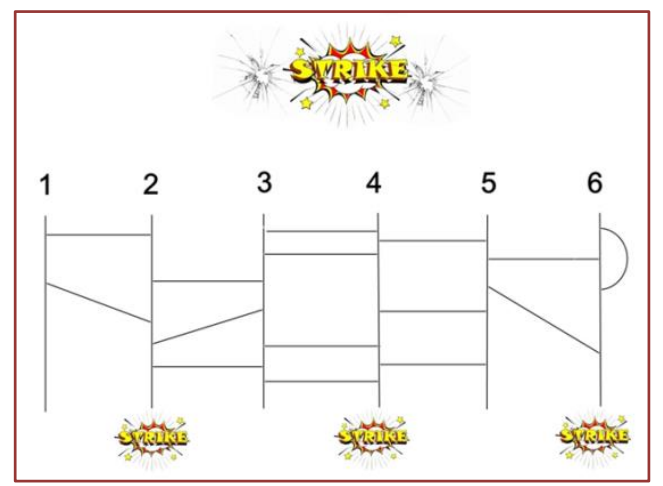

\section{REGRAS}

1 - 0 jogo consiste de seis rodadas e um total de seis caminhos que podem ou não ajudar um viciado em drogas a se reabilitar. A cada rodada um caminho deverá ser escolhido e não poderá ser repetido

2 - Ao escolher um caminho segue se a linha vertical de cima para baixo, no entanto, se uma linha horizontal ou diagonal aparecer deve-se obrigatoriamente seguila, como no exemplo abaixo:

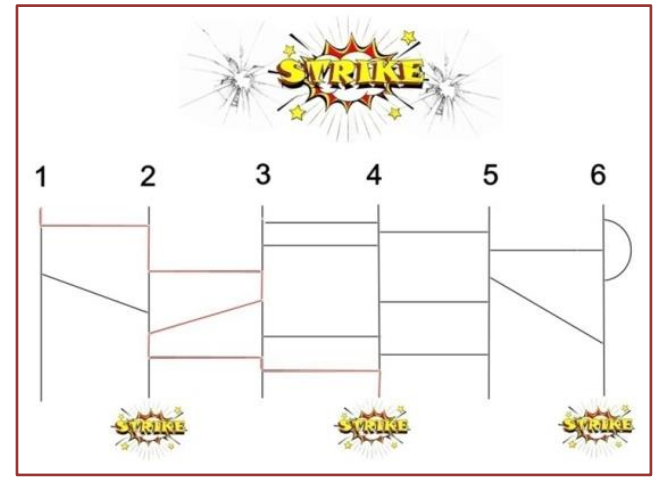


a) Nenhum dos caminhos se encerra no mesmo local cada um possui uma rota única com início e fim distintos.

b) Ao chegar ao final do caminho escolhido, ele poderá estar livre das influências das drogas ou possuir um strike.

c) Cada strike corresponde à quando um viciado em drogas que tenta se recuperar retorna a consumi-las devido às crises de abstinência. Esta etapa resulta em punição para os jogadores.

\section{PUNIÇÃo}

Strike: Você foi pego se deixando consumir pelo vício, sua reabilitação não vai nada bem! Vença a rodada ou perca 30 pontos.

3 - As rodadas devem consistir de cinco perguntas cada com questões voltadas para o tema Drogas. 0 jogador que acertar mais perguntas vence a rodada e adquire 50 pontos. Ao final das seis rodadas, o jogador que possuir a maior pontuação vencerá.

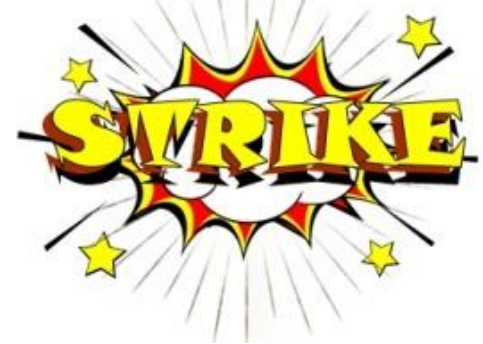




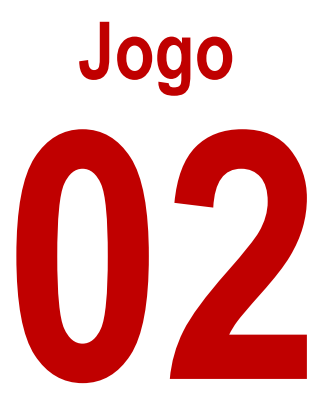

\section{Drogas: Conhecimento em ação}

Marina M. O. Silva, Wivian S. Mesquita, Victor Luís F. Lima, José Amilcar M. Araújo Neto, Dayana C. Braga, Luana C. Silva, Sofia P. Guillén(*), Giovanni B. S. Maia(*)

\section{INTRODUÇÃO}

O jogo didático é uma ferramenta de auxílio ao professor na sala de aula. Através do método lúdico há uma maior interação entre aluno e professor, tornando a aprendizagem mais facilitada e melhor aproveitada. Acredita-se que os jogos de caráter educativo além de expor conteúdos estimulam novas experiências como o trabalho em grupo. Nesse jogo o professor, ao mesmo tempo em que ensina Química através de estruturas e funções químicas das moléculas das drogas, apresenta também as prováveis consequências de seu consumo. "Drogas, conhecimentos em ação" é um jogo composto por 110 cartas, podendo ser jogado por no mínimo duas pessoas e no máximo cinco.

O jogo começa com a distribuição de cinco cartas para cada participante; em sua vez o jogador deve apanhar duas cartas da pilha de saque e pode realizar até três jogadas (cada carta baixada na mesa equivale a uma jogada). No final de cada jogada individual, os jogadores deverão ter no máximo sete cartas na mão, caso esse limite exceda descarta-se a quantidade necessária para voltar ao padrão. Ganha o jogador que primeiro formar três conjunto(s) completo(s) de Títulos de Conhecimentos de drogas diferentes.
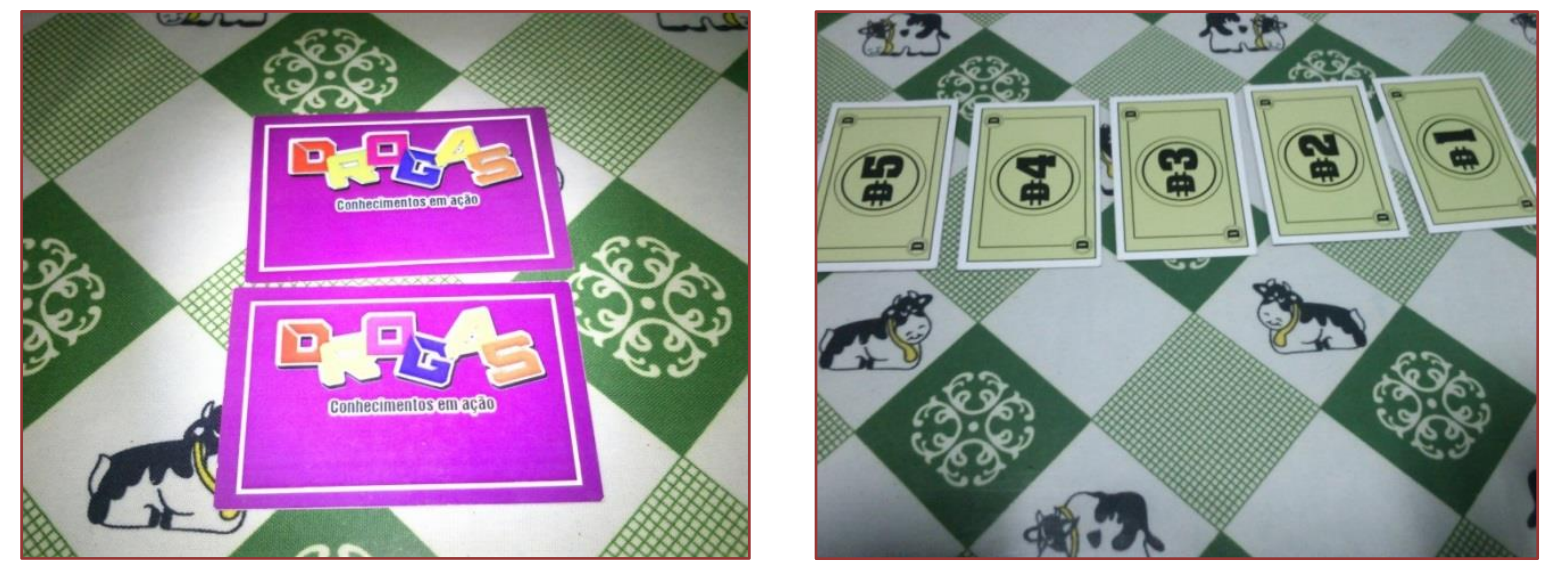

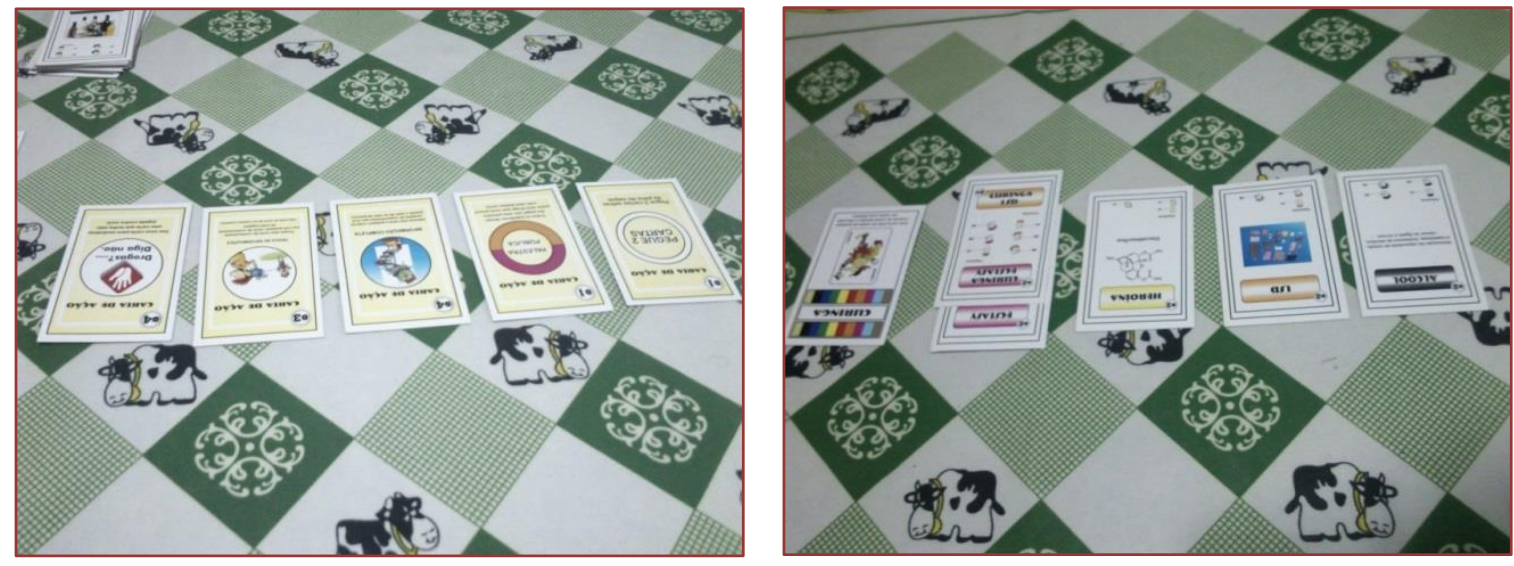

\section{RESULTADOS E CONCLUSÃO}

O jogo foi criado em um Grupo de Estudos sobre Drogas de Abuso do Curso de Licenciatura em Química da Universidade Estadual do Ceará buscando aliar ao ensino de Química um maior entendimento sobre as drogas abusivas e seus efeitos. Através do mesmo, observou-se, que por meio da ludicidade, a aprendizagem da Química sobre os grupos funcionais, bem como a conscientização sobre o uso das drogas foram bemsucedidas. Como ratifica Lima (2009) ao afirmar que o lúdico como material disponível para ser executado em sala de aula e laboratório, tendo os próprios estudantes como aliados é mais uma ferramenta de ensino-aprendizagem que o professor dispõe. Através deste método observa-se que o professor não deve atuar unicamente como apresentador dos conteúdos e sim como mediador, criando um ambiente de construção e exploração do conhecimento.

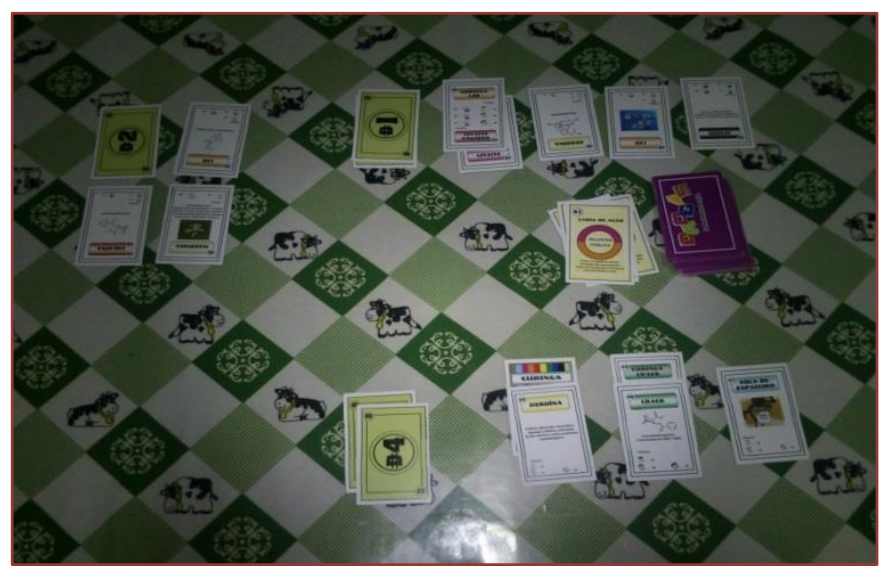




\section{Jogo \\ 03 Ajude-me \\ Valdiana Gomes Cavalcante}

\section{INTRODUÇÃO}

0 jogo a ser apresentado faz referência aos problemas com as drogas, onde cada participante atua em conjunto com os demais, almejando a reabilitação do personagem principal. Caso o grupo consiga reabilitar a vítima, todos ganham. Caso contrário, o grupo perde. 0 objetivo do jogo é conscientizar de que o combate às drogas requer a colaboração de todos.

\section{OBJETIVO}

Esclarecer a importância da ajuda da comunidade inteira no enfrentamento do problema das drogas com os jovens.

\section{№ DE PEÇAS}

50 CARTAS (1ํㅡㅁ baralho para as cartas das drogas e do traficante -15 cartas - $2^{\underline{o}}$ baralho para as cartas de combate e do dinheiro - 33 cartas - e 2 cartas para a escolha dos personagens, totalizando 50 cartas).

№ DE PARTICIPANTES: 3 A 6 participantes.

\section{REGRAS DO JOGO}

1. Ao iniciar o jogo embaralhe as cartas do $1^{\circ}$ e $2^{\circ}$ baralho e escolha um dos dois personagens;

2. Em seguida escolha uma carta do $1^{\circ}$ baralho para saber o problema a ser enfrentado pelo personagem que a equipe deve ajudar e entregue 3 cartas do $2^{\circ}$ baralho para os participantes;

3. $02^{\circ}$ baralho contém as cartas de solução do $1^{\circ}$ baralho. As cartas do $1^{\circ}$ baralho possuem os tópicos que são as possíveis soluções;

4. Jogue o dado para saber quem irá começar o jogo, lembrando que o jogo será seguido em sentido horário;

5. 0 jogo é feito com 3 rodadas, onde cada rodada que houver o objetivo concluído, 1 ponto será somado para a equipe, caso contrário a equipe perderá 1 ponto.

6. Ao final das 3 rodadas há a contagem dos pontos ganhados ou perdidos no jogo. Caso totalize -2 ou -3 ponto a equipe perde e o personagem não foi, suficientemente ajudado. 
7. Ganha a equipe que totalizar +2 ou +3 pontos.

8. Lembrando que formado a equipe, não possui participantes ganhadores ou perdedores. A equipe ganha ou perde em conjunto.

\section{CARTAS}

1 - Cartas dos personagens e imagem do verso das cartas.

2 - 1ํ Baralho (cartas das drogas e do personagem traficante).

3 - 2ํㅡㅁ Baralho (cartas da solução - cartas de combate e dinheiro)

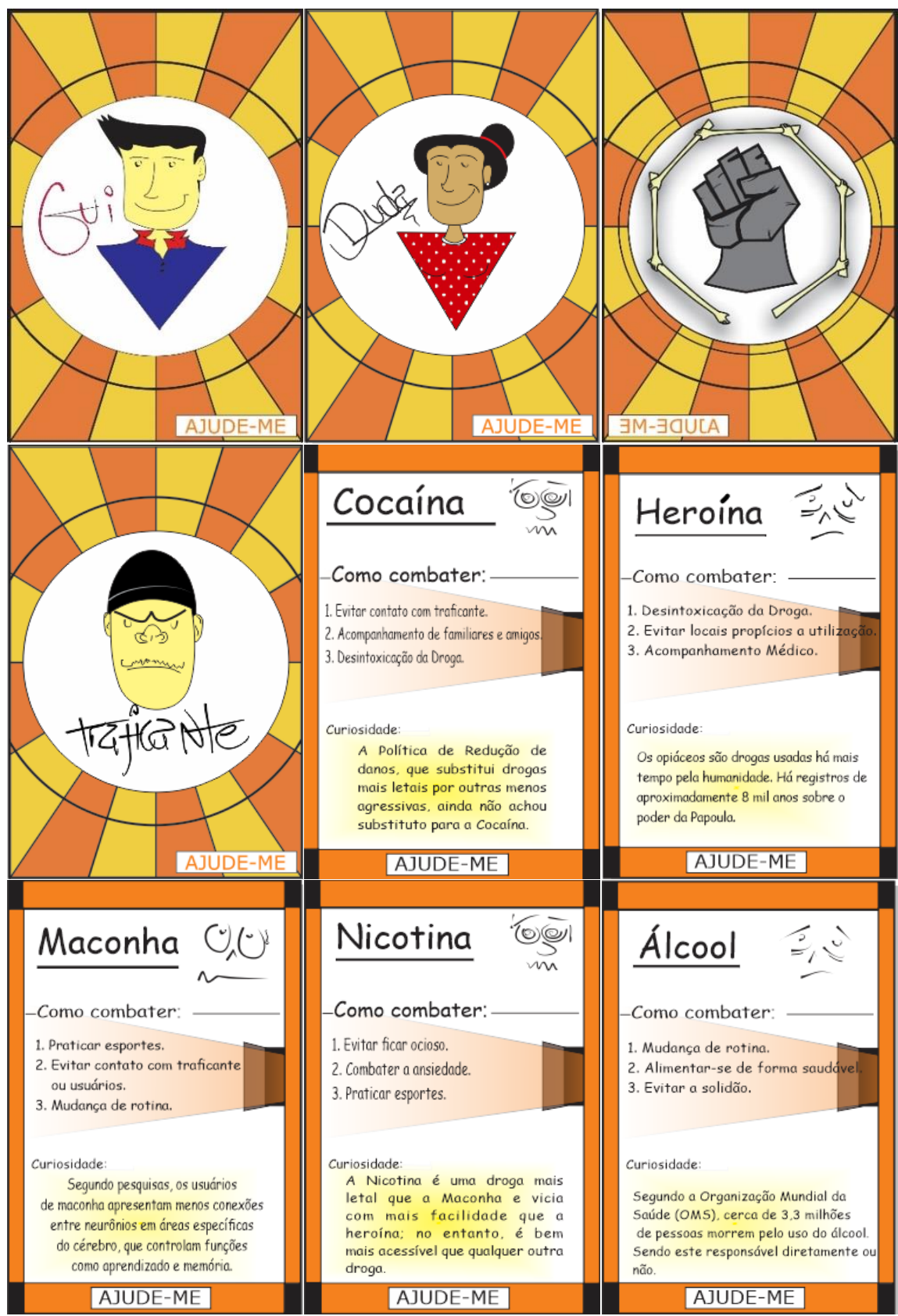




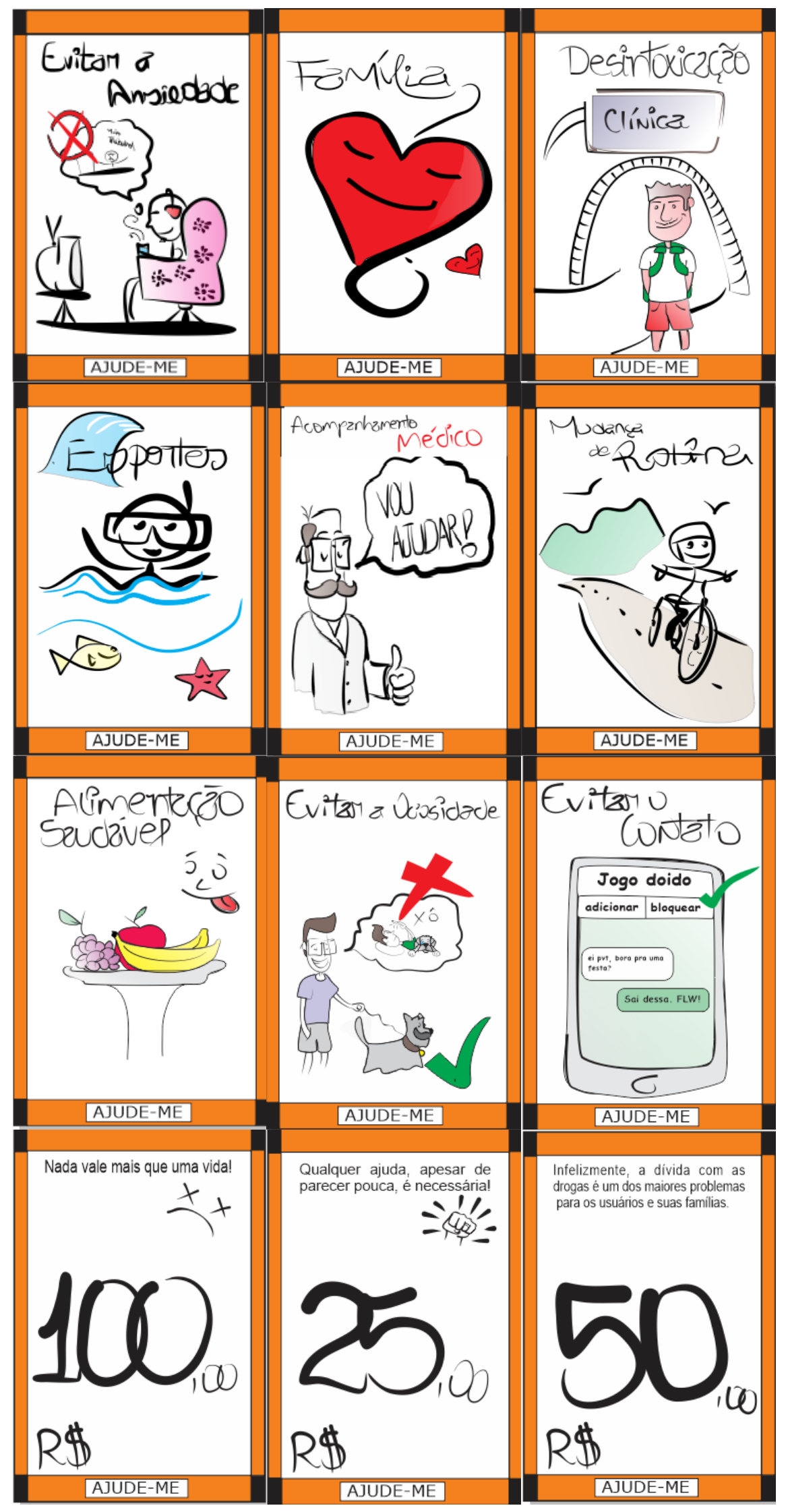




\section{Jogo \\ 1 Você conhece as drogas de abuso? \\ Ivana Carneiro Romão; Késsia Oliveira Targino}

\section{INTRODUÇÃO}

O uso de drogas na adolescência é uma questão que preocupa cada vez mais os pesquisadores e profissionais da saúde e educação. As pesquisas epidemiológicas mostram que o uso e abuso de drogas aumenta em ritmo acelerado e que é na adolescência que, em geral, inicia-se o consumo. No inquérito nacional realizado pelo Centro Brasileiro de Informações sobre Drogas Psicotrópicas (CEBRID), em 2004, os escolares dos ensinos fundamental e médio de 27 capitais brasileiras apresentaram $23,5 \%$ de prevalência de uso de drogas, exceto álcool e tabaco, no sexo masculino, e $21,7 \%$, no sexo feminino. Em outro inquérito acerca do tabagismo, aplicado no Ensino Fundamental na idade de 13 a 15 anos, a variação foi de 58\% no sexo masculino, e 50\% no sexo feminino em Fortaleza, Ceará. Diante disso, buscamos abordar esse assunto de uma forma divertida e informativa criando o jogo "Até onde você sabe sobre drogas? "Com o objetivo de conscientiza-los sobre os efeitos das drogas de abuso, sobre a legislação, prevenção, mecanismos de ação, curiosidades, tipos de drogas, e sobretudo ensinar e alertar esses jovens sobre esse assunto tão importante.

\section{MATERIAIS E MÉTODOS}

O jogo é repleto de perguntas sobre os vários tipos de drogas e diversas cartas curiosidades para instigar esses alunos a discutir sobre o assunto.

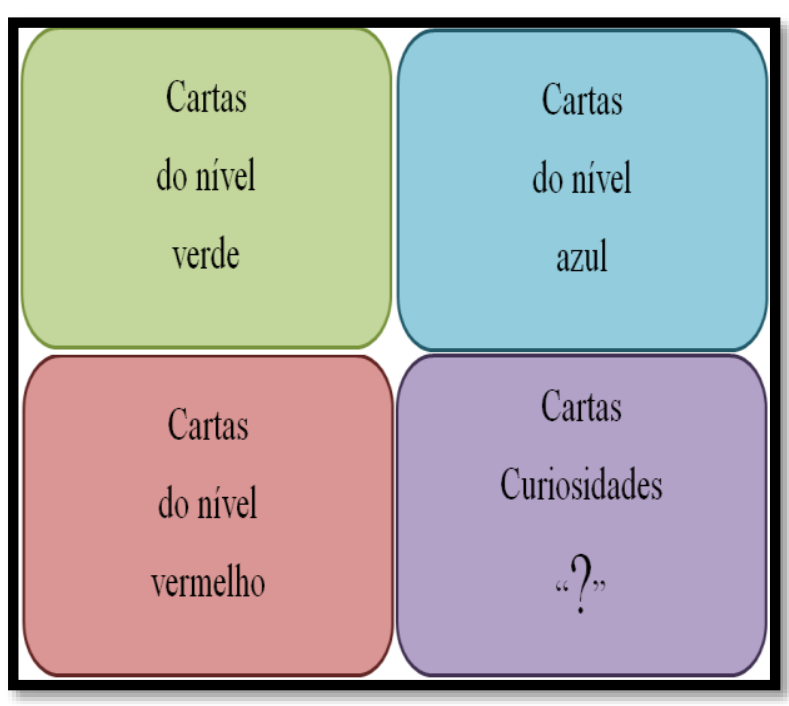


Figura 1. Demonstração dos tipos de cartas e tabuleiro do jogo

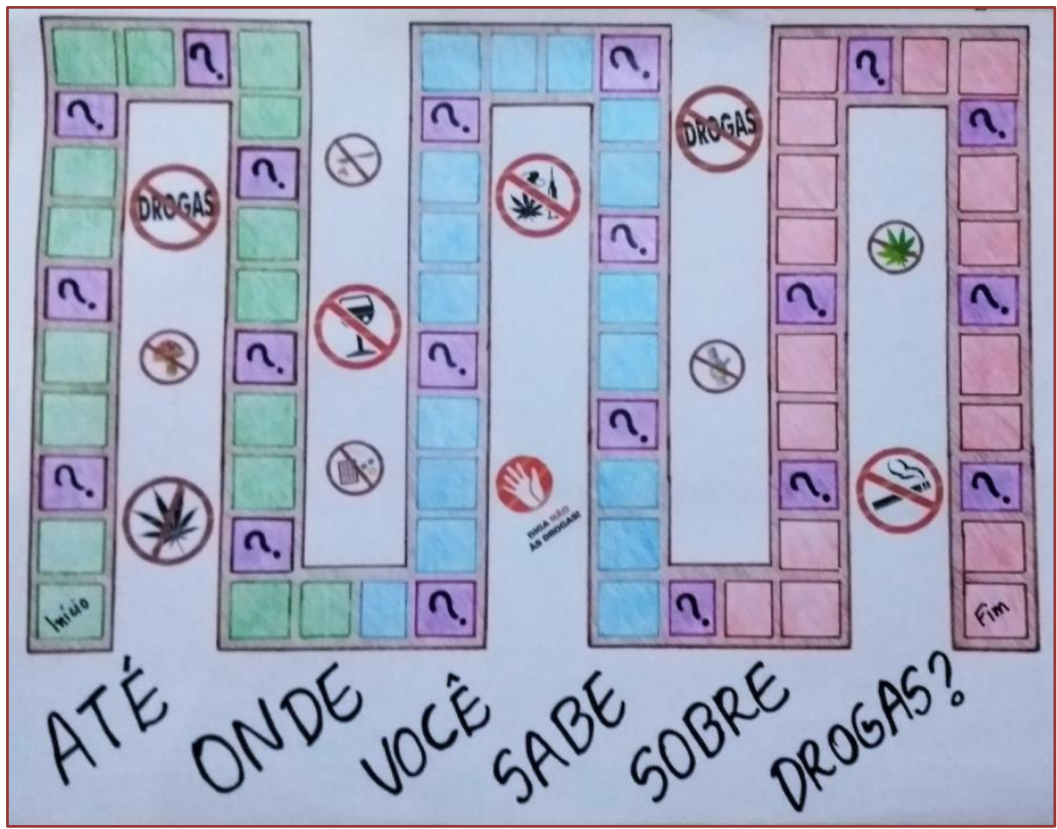

O jogo foi empregado nos alunos do Centro Educacional Construir na sala de 9o ano, e após a aplicação do jogo, foi entregue um questionário (figura 2) quantitativo e objetivo. A análise das respostas está descrita na tabela 1.

Tabela 1. Análise das respostas do questionário aplicado ao final do jogo.

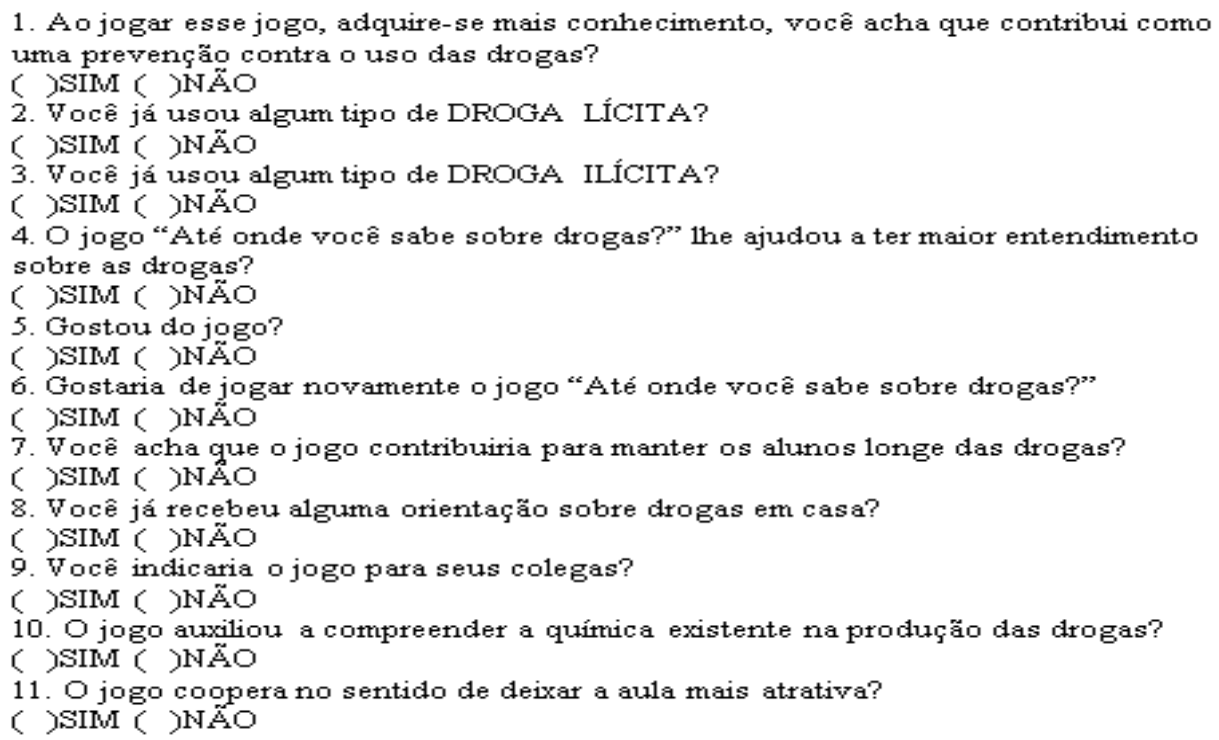


Tabela 1. Análise das respostas do questionário aplicado ao final do jogo.

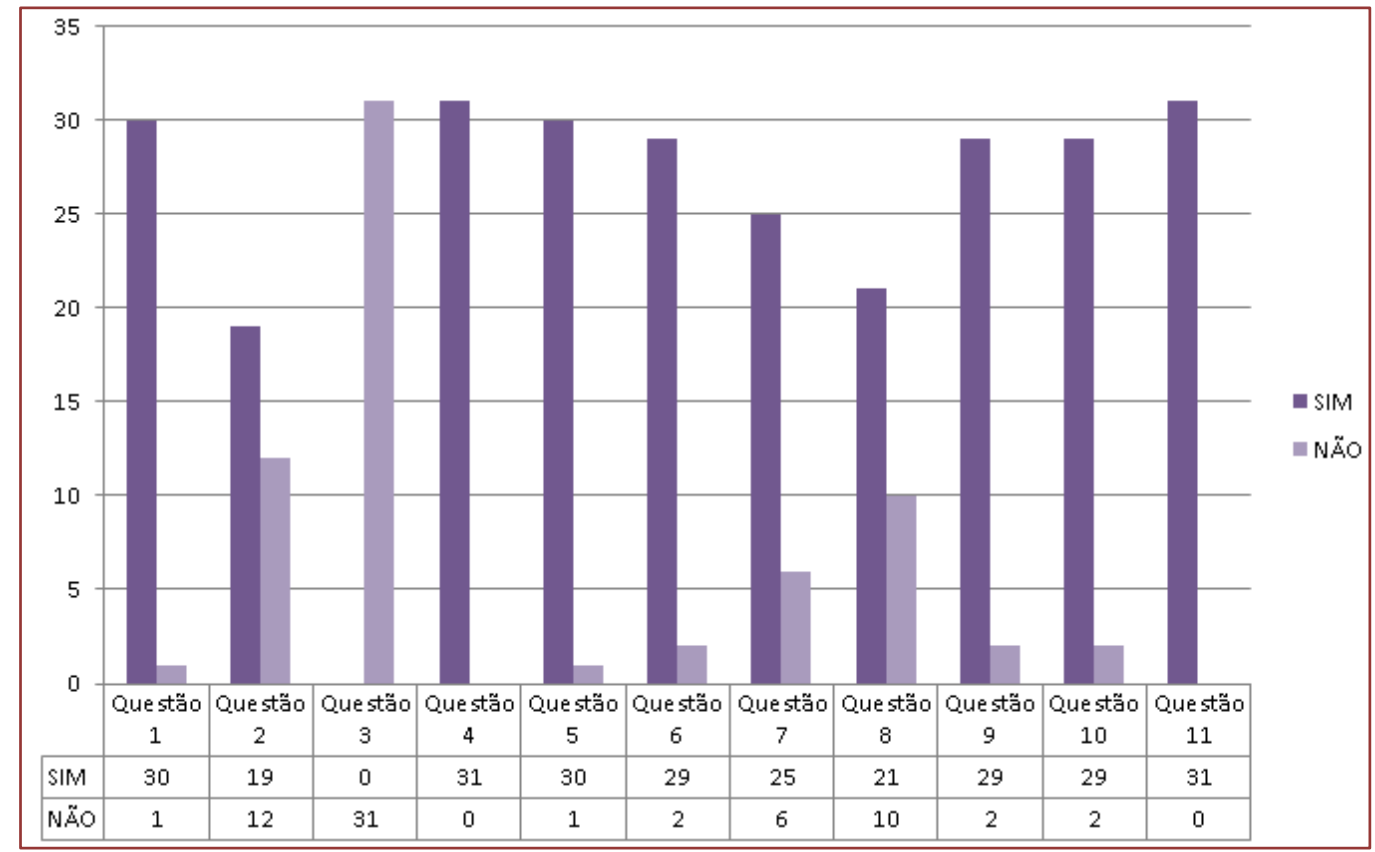

\section{CONCLUSÕES}

Pode-se concluir que o jogo conseguiu alcançar seu objetivo, pois as perguntas do jogo esclareceram várias dúvidas que os alunos tinham sobre o assunto, e permitiu que discutissem sobre situações que vivem no seu dia a dia. De acordo com a análise da tabela 1, o jogo pode agir como uma prevenção às drogas e como uma aula mais atrativa saindo daquele modelo de aula tradicional. 


\section{Jogo

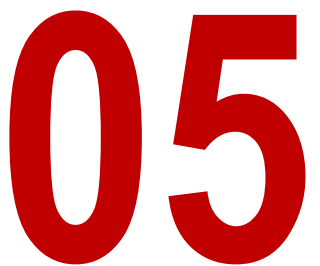 \\ Jogando com a Química das Drogas}

Kessia Oliveira Targino; Ivana C. Romão; Érica C. Sousa; Liara A. B. Pessoa; Renata Almeida Farias

\section{INTRODUÇÂO}

O ingresso na Universidade, ainda que traga sentimentos positivos e de alcance de uma meta programada por estudantes do Ensino Médio, por vezes pode se tornar um período crítico, de maior vulnerabilidade para o início do uso de álcool e outras drogas. 0 consumo de drogas continua a crescer e é considerado um problema de saúde pública devido aos seus efeitos nocivos, o que preocupa a comunidade brasileira. 0 uso de drogas em Universidades é um ato comumente praticado. No Brasil, existem 2.377 Instituições de Ensino Superior, das quais 278 são públicas e 2.099 privadas, distribuídas nos 26 Estados brasileiros e Distrito Federal. Em 2010, foi publicado o I Levantamento Nacional sobre o Uso de Álcool, Tabaco e outras Drogas entre Universitários de 27 Capitais Brasileiras, onde foi observado um grande abuso das drogas pelos alunos. Devido a esse fato foi criado um jogo "Drogas Trívia" com objetivo de levar conhecimento sobre drogas aos universitários, sobre como funciona, como são produzidas e quais os efeitos destas a curto bem como a longo prazo. Assim o jogo será um instrumento de prevenção para os alunos que estão iniciando sua vida adulta.

\section{MATERIAIS E MÉTODOS}

O jogo "Drogas Trívia" é repleto de perguntas que desafiam o conhecimento trazendo diversas curiosidades e explicações sobre as drogas lícitas e ilícitas aos estudantes do Ensino Superior. No jogo há quatro categorias que são representadas por figuras (figura 1) e o competidor só ganhará se conseguir as quatro figuras que representam cada uma das categorias.

Figura 1. Figuras que representam as categorias do jogo

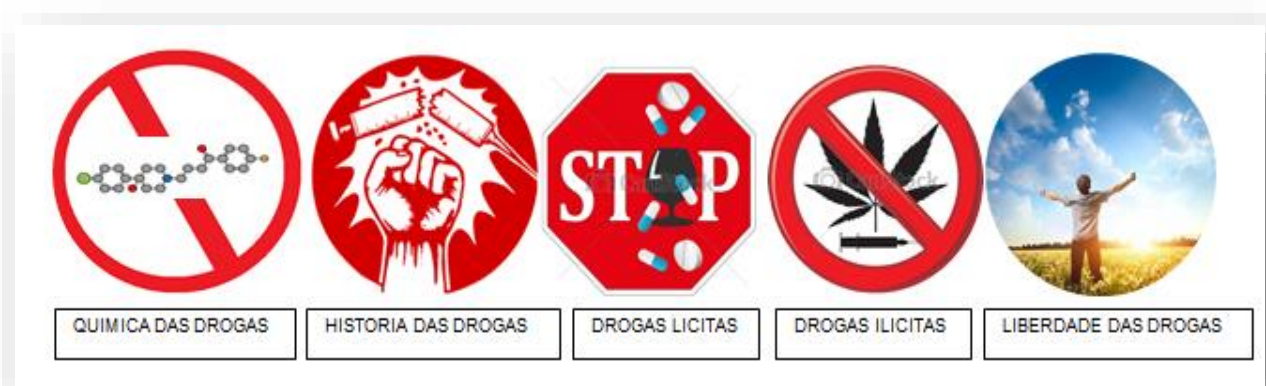


O jogo foi empregado em discentes da Universidade Estadual do Ceará, e após a aplicação do jogo, foi entregue um questionário (figura 2) quantitativo e objetivo. As respostas constam da tabela 1.

Figura 2. Questionário: Avaliação da aplicação do jogo.

1. Ao jogar o jogo, adquire-se mais conhecimento, você acha que contribui como uma prevenção contra o uso de drogas?

( ) $\operatorname{SIM}($ ) NÃO

2. Você Já usou algum tipo de droga licita?

( ) $\operatorname{SIM}($ ) NÃO

3. Você já usou algum tipo de drogas ilícitas?

( ) $\operatorname{SIM}($ ) NÃO

4. O jogo Baseado em Drogas the ajudou a ter maior entendimento sobre as drogas?

( $) \operatorname{SIM}($ ) NÃO

5. Gostou do jogo?

(u) $\operatorname{SIM}($ ) NÃO

6. Gostaria de jogar novamente o jogo Baseado em Baseado em Drogas?

( ) $\operatorname{SIM}($ ) NÃO

7. Você acha que o jogo contribuiria para manter os alunos longe das drogas?

( ) $\operatorname{SIM~(~)~NÃO~}$

8. Você já recebeu alguma orientação sobre drogas em casa?

( ) $\operatorname{SIM}($ ) NÃO

9. Você indicaria o jogo para seus colegas?

( ) $\operatorname{SIM}($ ) NÃO

10. O jogo auxiliou a compreender a química existente na produção das drogas?

( ) $\operatorname{SIM}($ ) NÃO

Tabela 1. Análise das respostas do questionário aplicado no final do jogo.

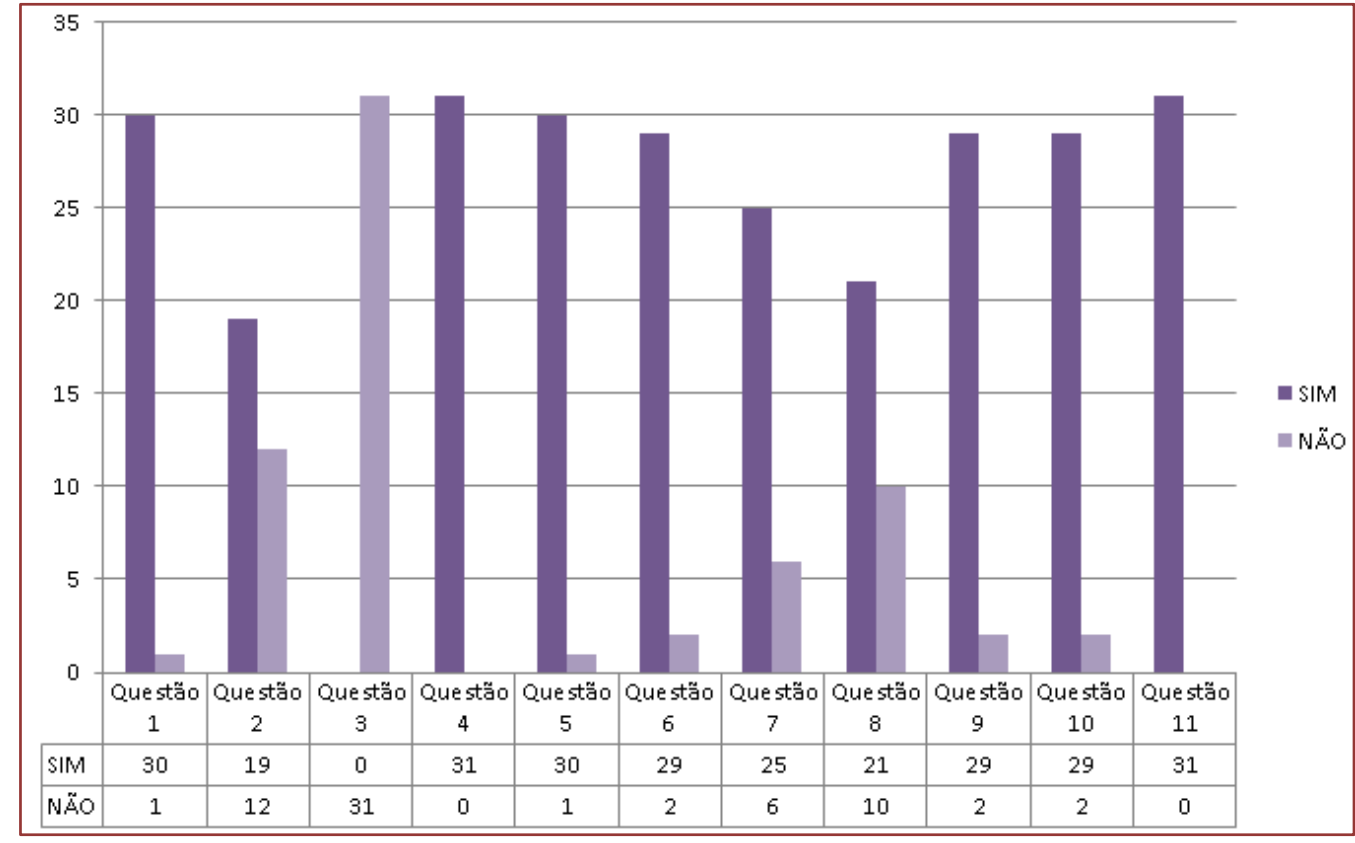




\section{CONCLUSÕES}

E a partir das respostas obtidas concluiu-se que o jogo educativo sobre drogas é uma ótima forma de abordar o assunto em sala de aula, uma vez que a maioria dos jogadores não tem orientações em casa, levando conhecimento para os estudantes universitários como forma de prevenção aos possíveis riscos. 


\section{Jogo \\ (1) Roleta Química \\ Kamila de Lima Barbosa; Kananda Lara Santos Sales; Amanda Batista Nascimento; Kessia Oliveira Targino; Renata Almeida Farias; Lucas \\ Lima Bezerra}

\section{INTRODUÇÃO}

A abordagem do tema drogas, durante muito tempo, foi apontada como tabu nas escolas brasileiras. 0 ambiente escolar não é separado da maior parte da sociedade e é preciso traçar caminhos que aproximem mais esses dois meios. Ainda que as causas da violência e dos problemas de saúde que encontramos no âmbito social sejam relacionadas em grande parte ao consumo de drogas e a dificuldade de discutir tal assunto em relação à prevenção e ao consumo.

Partindo dessa premissa, foi elaborado um jogo educativo sobre a química das drogas, uma espécie de roleta a fim de não só dinamizar o ensino, como ainda alertar sobre o uso de drogas de abuso. Em virtude da carência de métodos para a interação ensino-aprendizagem que propiciem uma maior aproximação, uma vez que a maioria das ferramentas utilizadas é restrita a livros, os jogos lúdicos vêm como um instrumento no processo de ensino e aprendizado de forma descontraída.

\section{MATERIAIS E MÉTODOS}

Figura 1: Roleta Química

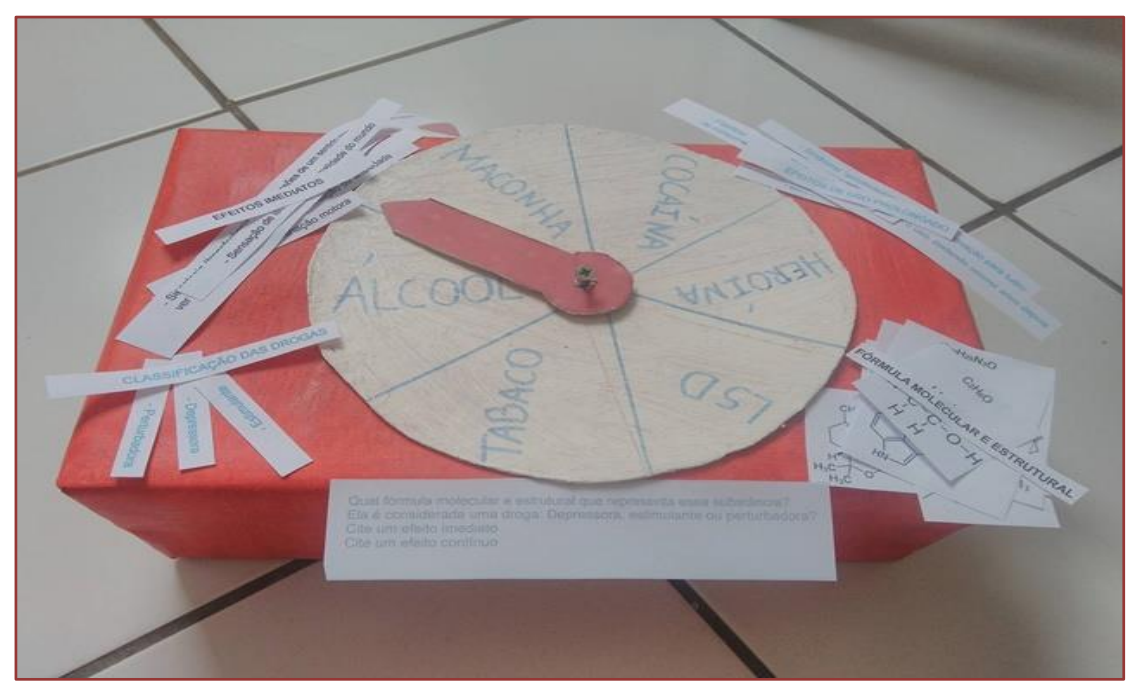

O jogo Roleta Químicafoi elaborado por um grupo de estudantes do curso de Licenciatura em Química da Universidade Estadual do Ceará. Foram utilizados materiais reciclados para sua produção. 0 jogo será dividido em 3 grupos de alunos, no máximo 3 pessoas, que conta com uma roleta química onde estão dispostos 6 tipos de drogas, consideradas as mais consumidas entre os alunos nas instituições de ensino brasileiras, e com elas cartas contendo 4 perguntas referentes a droga selecionada na roleta. Depois 
de indicada o grupo irá associar, por meio de fichas dadas aos participantes, a fórmula molecular e estrutural da substância, se é considerada uma droga depressora, estimulante ou perturbadora e quais seus efeitos de uso imediato e contínuo. Tendo por fim da partida o grupo que mais relacionou corretamente a droga com as perguntas apresentadas.

\section{RESULTADOS E DISCUSSÃO}

0 jogo educativo foi aplicado em um grupo de alunos do $9^{\circ}$ ano do Colégio Monteiro Lobato (Fortaleza-Ce), tendo como propósito relatar uma experiência pedagógica, onde os alunos puderam se familiarizar com as substâncias e suas fórmulas dentro de conteúdos químicos. Após o jogo, foi distribuído um questionário para saber se a turma havia aprovado a aula como um jogo lúdico. Percebeu-se que $90 \%$ dos alunos aprovaram o jogo como uma ferramenta capaz de estimular e aumentar seus conhecimentos não só em relação ao ensino da química, como também uma forma de alerta ao uso de drogas. Essa proposta apresenta um recurso facilitador no ensino da química, além de interagir e dinamizar a situações no dia-a-dia.

\section{CONCLUSÃO}

A metodologia lúdica empregada contribuiu para manter os alunos motivados em sala de aula, fazendo-os não só interagirem entre si, mas também com o professor, facilitando ao aluno a construção do conhecimento junto ao docente. Com os resultados obtidos, pode-se concluir que a prática de ensino através de jogos é uma alternativa válida e com resultados positivos no que se refere ao conteúdo que se deseja ensinar. Deve-se ressaltar ainda a conscientização dos alunos sobre as consequências do uso de drogas de abuso. 


\section{Jogo \\ 07 \\ Jogando se aprende a Química das drogas \\ Kamila de Lima Barbosa; Paulo Roberto Santos de Lima, Álvaro Ventorini Vasconcelos, Geovana Costa Aguiar}

\section{INTRODUÇÃO}

Pesquisas apontam que o ensino da Química é em geral tradicional, ou seja, dispõe-se apenas de livros para memorização de nomes, fórmulas e cálculos, muitas vezes desvinculados do dia-a-dia. Como forma de buscar novas alternativas para melhor atrair os alunos a esse universo, os jogos lúdicos entram como um método de ensino de modo a motivar e facilitar o processo de aprendizado.

Esta nova prática de ensinar vem sendo explorada pelos professores e tendo grande aceitação por parte dos alunos, demonstrando excelentes resultados. Os mesmos proporcionam uma metodologia inovadora e atraente para ensinar de forma mais prazerosa e interessante, já que a falta de motivação é a principal causa do desinteresse dos alunos, quase sempre acarretada pela metodologia utilizada pelo professor, ao repassar os conteúdos.

A criação de um jogo lúdico desenvolvido como parte das atividades do projeto de extensão, visando não só o despertar do ensino da Química das substâncias ilícitas e licitas, mas também criar um alerta acerca do consumo de drogas.

\section{MATERIAL E MÉTODOS}

Figura 1.Cartas do jogo

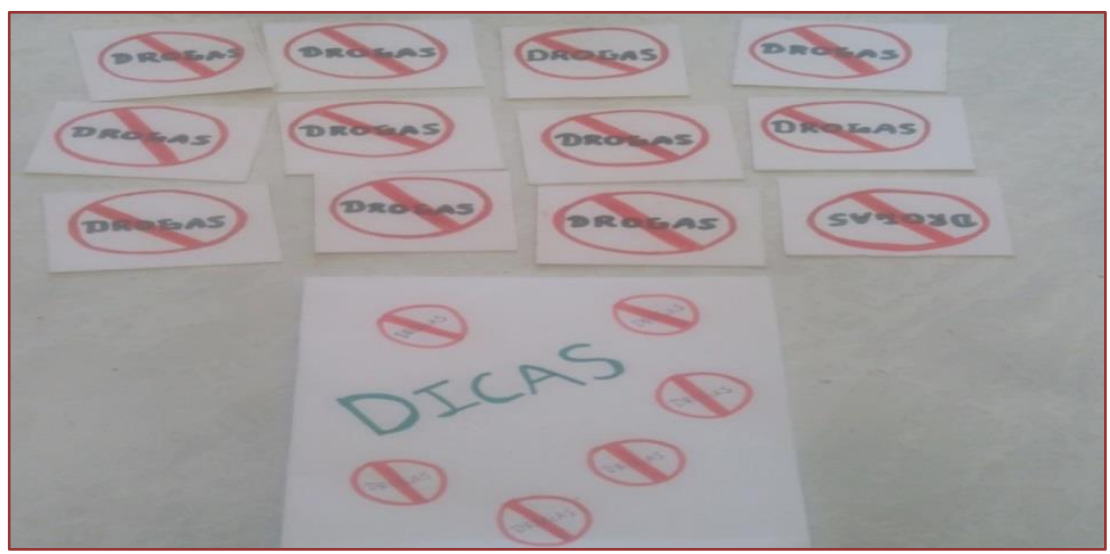

O jogo é feito usando uma espécie de adivinhação. 0 número de jogadores é no mínimo 2 e máximo 6.0 mesmo conta com 12 cartas, feitas de cartolina, viradas para baixo com cada carta referente ao nome de uma droga, seja ela ilícita ou lícita. 0 jogador 
que retirar a carta vai mostrar aos outros integrantes, que por meio de dicas o farão tentar adivinhar de qual substância se trata. As dicas dispõem de fórmulas químicas, peso molecular, nome na IUPAC, classificação da droga: perturbadora, depressiva ou estimulante, tipo de administração e efeitos colaterais. 0 jogo é cronometrado ganhando ao final o jogador que adivinhar em um menor tempo.

\section{RESULTADOS E DISCUSSÃO}

Para verificar a viabilidade do uso deste jogo em sala de aula, o mesmo foi aplicado em alunos do curso de Licenciatura em Química da Universidade Estadual do Ceará, tendo como intuito relatar uma experiência pedagógica. Os participantes concluíram que esse jogo será de máxima importância para a sua utilização nas atividades docentes. De forma geral os jogos apresentaram uma excelente aprendizagem na disciplina, dando ao aluno motivação para o estudo da química. Foi observado que o assunto gerou interesse e curiosidades pelos alunos, tornando a aprendizagem ao final satisfatória. Também foi possível perceber que houve uma socialização entre os alunos, tornando-os mais aptos a absorverem os assuntos em sala de aula.

\section{CONCLUSÃO}

Com a elaboração deste trabalho, foi observado que os alunos tiveram uma participação ativa no seu processo de aprendizagem e crescimento pessoal, uma vez que a cooperação melhora a eficácia da ação pedagógica. Desta forma, a proposta de se trabalhar com jogos apresentou resultados satisfatórios, podendo ser considerada uma abordagem adequada para se ensinar o conteúdo aplicado ao ensino da Química. 


\section{Jogo \\ 08 Édroga mesmo! \\ Ítalo Ramon Rocha Muniz; Francinildo da Silva Brito}

\section{INTRODUÇÃO}

Esse jogo foi idealizado para fornecer ao aluno do Ensino Médio ações preventivas envolvendo as drogas. Ele apresenta as conseqüências causadas pelo uso das drogas de abuso. 0 objetivo do jogo envolve o jogador a ajudar aos usuários de drogas a encontrar o caminho de suas casas. Para isso é necessário responder corretamente as perguntas e respeitar as ações impostas aos jogadores no tabuleiro.

\section{MATERIAIS E MÉTODOS}

0 jogo consta de um tabuleiro, dados e perguntas a serem respondidas. Cada jogador na sua vez joga o dado e anda as casas que ele indicar. Caso pare nas perguntas será necessário respondê-las corretamente para avançar o indicado pelo dado. 0 jogador deve respeitar as ações no tabuleiro para avançar, retornar algumas casas ou ficar sem jogar rodadas seguintes. Será estipulado um tempo de 1 hora para duração do jogo.

\section{METODOLOGIA}

\section{Ações no Tabuleiro}

1. Atividades esportivas: Avança 2 casas;

2. Desapareceu com os móveis de casa: Fica sem jogar 2 rodadas;

3. Diminuiu o consumo de drogas: Jogue outra vez;

4. Ofereceu drogas aos amigos: Voltar ao início do jogo;

5. Parada obrigatória na clínica de reabilitação: Ficar 1 rodada sem jogar, porém, ganha ajuda na próxima pergunta (ficha de ajuda);

6. Placa de advertência: Responder corretamente à pergunta e andar a quantidade de casas que o dado indicar. Nas respostas erradas não andará as casas indicadas no dado.

7. Reconheceu que precisa de ajuda: Avançar 3 casas;

8. Visita de familiares: Avançar 4 casas.

9. Voltou a usar drogas (recaída): 0 jogador que parar nessa ação responderá 2 perguntas seguidas para prosseguir no jogo, caso contrário ficará uma rodada sem jogar. 
Figura 1: Tabuleiro e Cartas

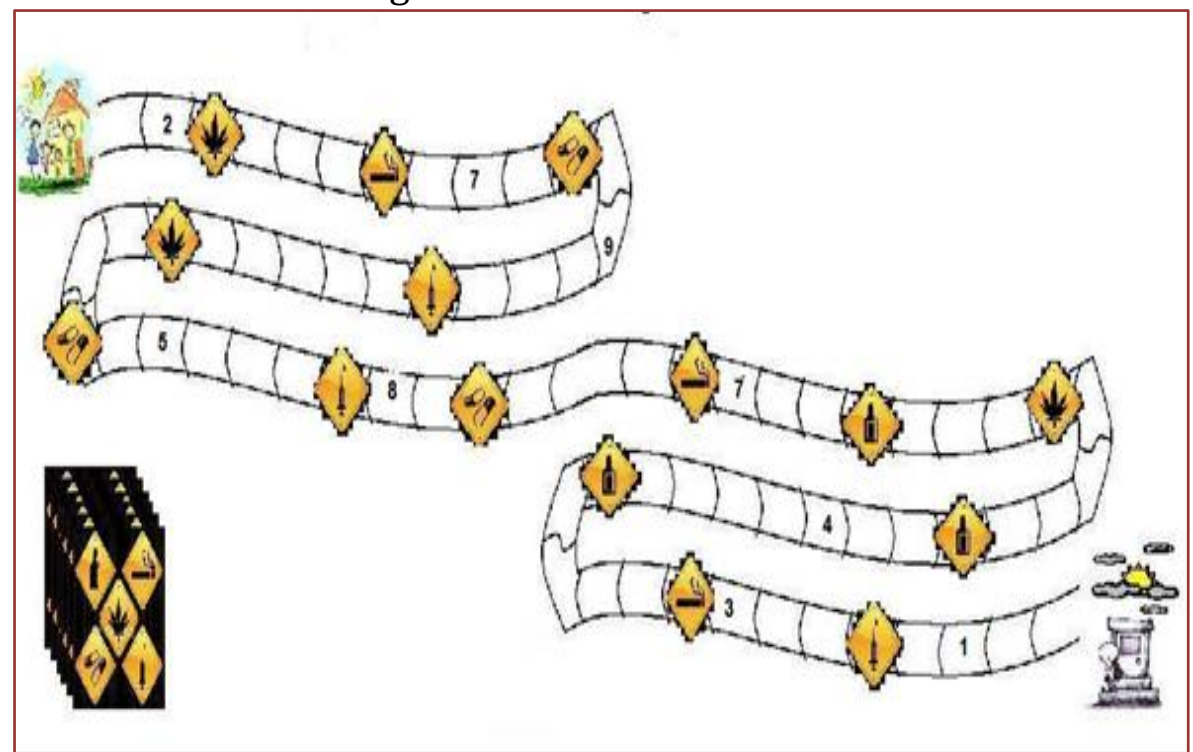

\section{RESULTADOS}

O jogo foi experimentado em grupos de alunos do Curso de Licenciatura em Química da Universidade Estadual do Ceará que fazem parte do "Grupo de Estudos sobre Drogas de Abuso", obtendo 100\% de aceitação.

\section{CONCLUSÃO}

A partir da aceitação obtida concluiu-se que o jogo educativo sobre drogas é uma ótima forma de abordar o assunto em sala de aula, uma vez que a maioria dos jogadores não tem orientações em casa, levando conhecimento para os estudantes do Ensino Fundamental e Médio como forma de prevenção aos possíveis riscos. 


\section{Jogo \\ (1) Uma aula de química diferente \\ Micaelle Ribeiro dos Santos Gomes; Renata Almeida Farias; Ítalo Ramon Rocha Muniz.}

\section{INTRODUÇÃO}

Discutir os malefícios das drogas é de extrema importância para a base curricular de qualquer estudante de licenciatura em química em face de uma formação profissional.

Como futuros professores, sabe-se que há uma necessidade de desenvolver novos meios didáticos em sala de aula, para que esta possa ser facilitadora da abordagem e assimilação do conteúdo. Quando se fala em inovar aulas, pensa-se em Jogos lúdicos, pois estes atuam como ferramentas no processo de ensino e aprendizagem, podendo constituir uma alternativa prática e viável para auxiliar na construção ativa do conhecimento para o aluno (PEIXOTO et al., 2017). Dessa forma o jogo "DRUGSTER", foi confeccionado para auxiliar de forma divertida a abordagem deste trabalho de prevenção ao uso de drogas entre adolescentes nos últimos anos do ensino fundamental II.

\section{OBJETIVOS}

Conscientizar os alunos da $8^{\circ} \mathrm{e} 9^{\circ}$ serie quanto aos malefícios das drogas conhecendo as moléculas presentes em cada substância estudada.

\section{METODOLOGIA}

A metodologia foi dividida em quatro etapas: Aplicação de um questionário prévio utilizado para avaliar o grau de conhecimento do aluno; Uma aula expositiva sobre drogas e sua classificação, como Estimulantes psicomotores, Depressores do sistema nervoso central, Analgésicos Opioides, Solventes e Agentes psicomiméticos; Aplicação de um jogo lúdico, chamado "DRUGSTER"; E por fim um questionário final, avaliativo.

\section{CONCLUSÕES}

Através do questionário prévio observa-se o percentual de alunos que não sabem exemplificar drogas licitas e ilícitas nem a idade em que as pessoas começam um vício. É importante notar, que alunos da oitava e nona série já consumiram drogas. Dentre elas estão álcool, LSD e maconha. Durante as aulas devem ser abordados assuntos tais como a definição, classificação e efeitos das drogas, analisando cada molécula e como suas estruturas são semelhantes aos neurotransmissores Dopamina, Serotonina e etc. Através do questionário final obtém-se dados referentes ao aproveitamento quanto a classificação das drogas e suas consequências delas, bem como comprovando-se que a ludicidade no ensino é uma metodologia eficaz. 
Figura1. Tabuleiro DRUGSTER

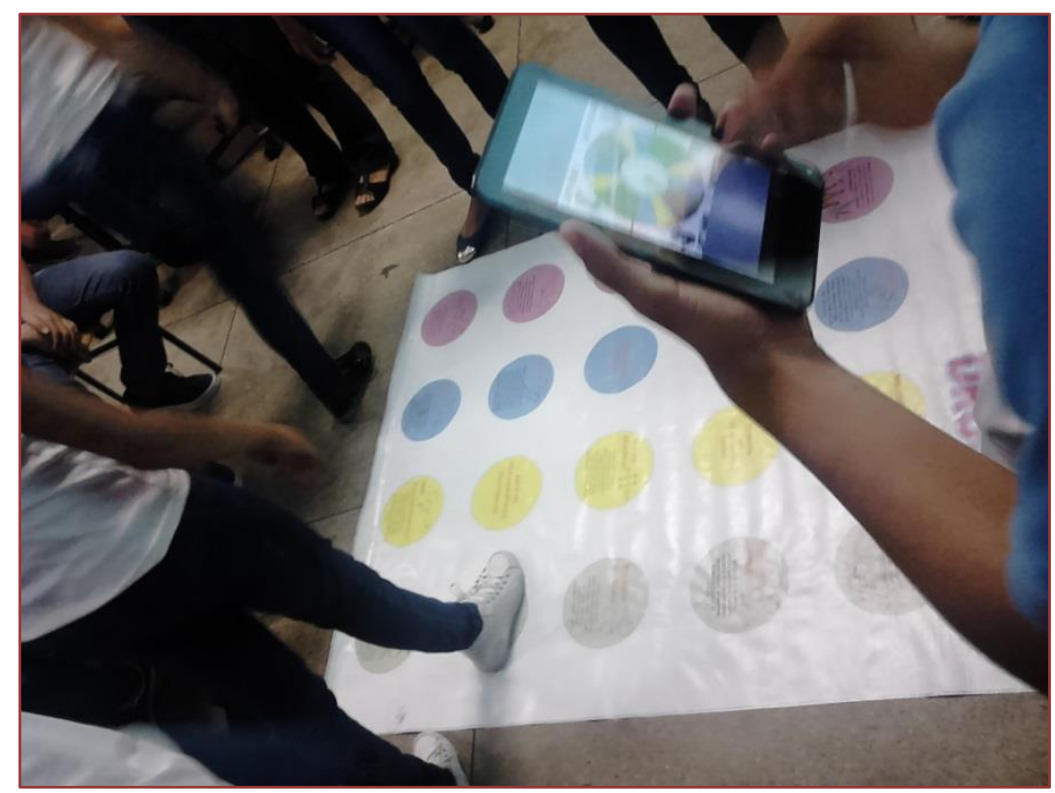




\section{Jogo \\ Embaralho das drogas \\ Marina Maciel de Oliveira Silva}

\section{INTRODUÇÃO}

Nesse jogo serão estudadas as drogas de abuso a partir de sua estrutura química, sua nomenclatura usual e científica.

\section{OBJETIVO DO JOGO}

A finalidade do jogo será formar um trio de cartas, com a imagem, a nomenclatura e efeitos respectivos relacionados à cada droga.

\section{COMO JOGAR}

Esse jogo é composto por 39 cartas que serão divididas em três grupos de jogadores. 0 primeiro grupo terá a imagem da droga. 0 segundo grupo terá o nome usual e cientifico da droga mais a estrutura do seu princípio ativo enquanto o terceiro grupo abordará os efeitos de determinada droga.
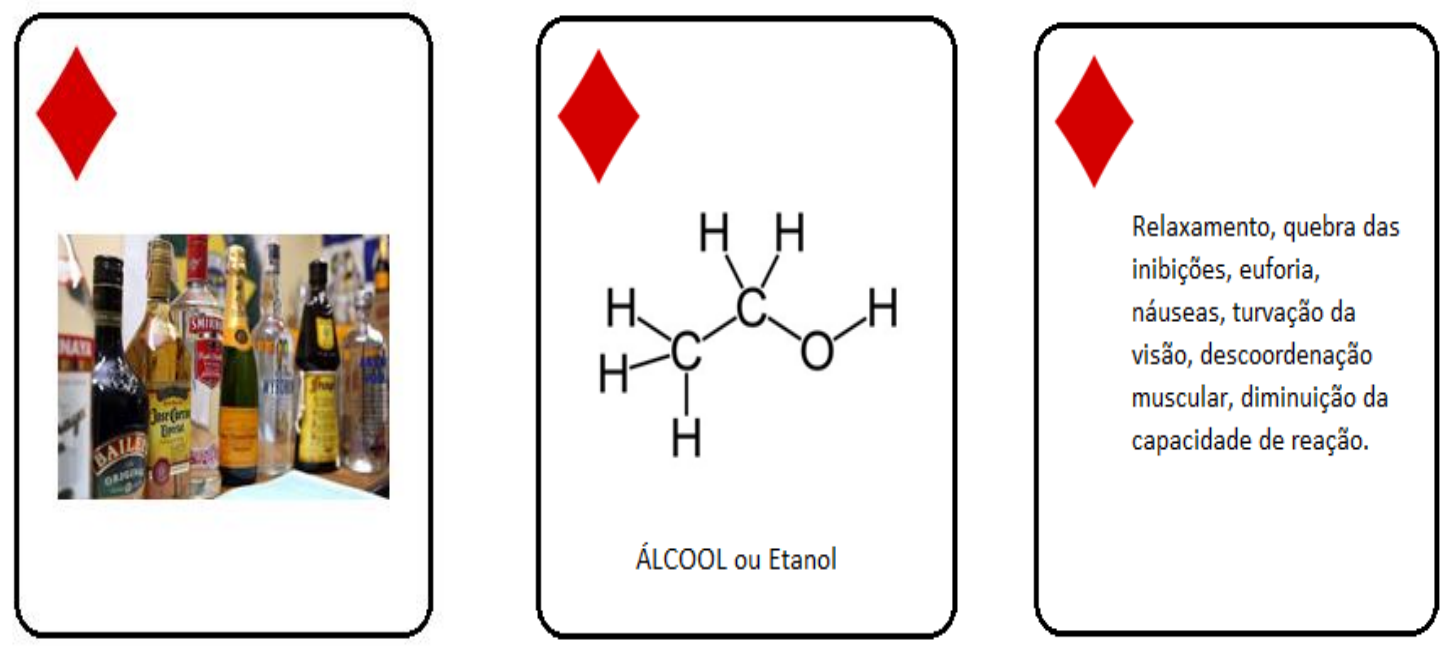

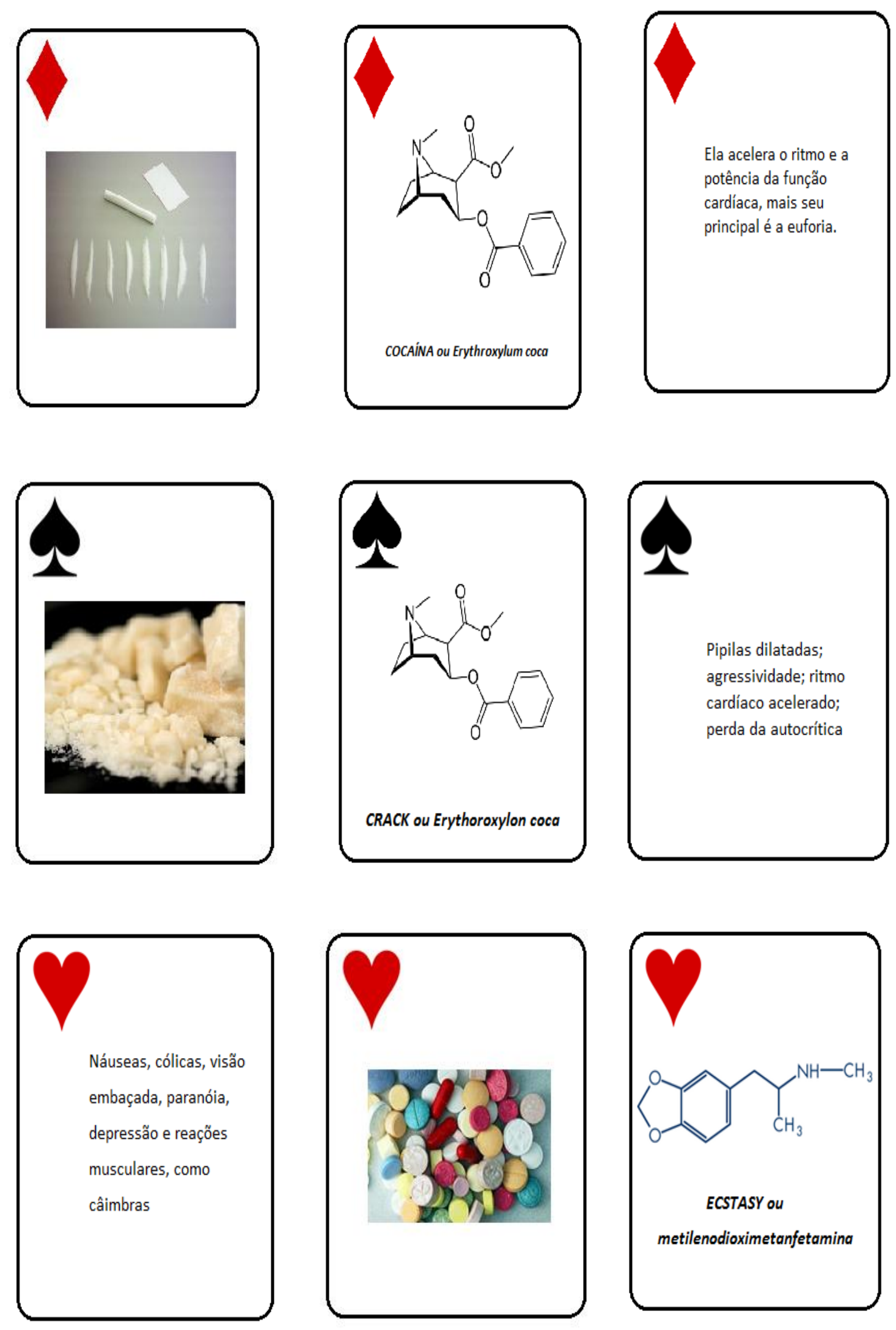

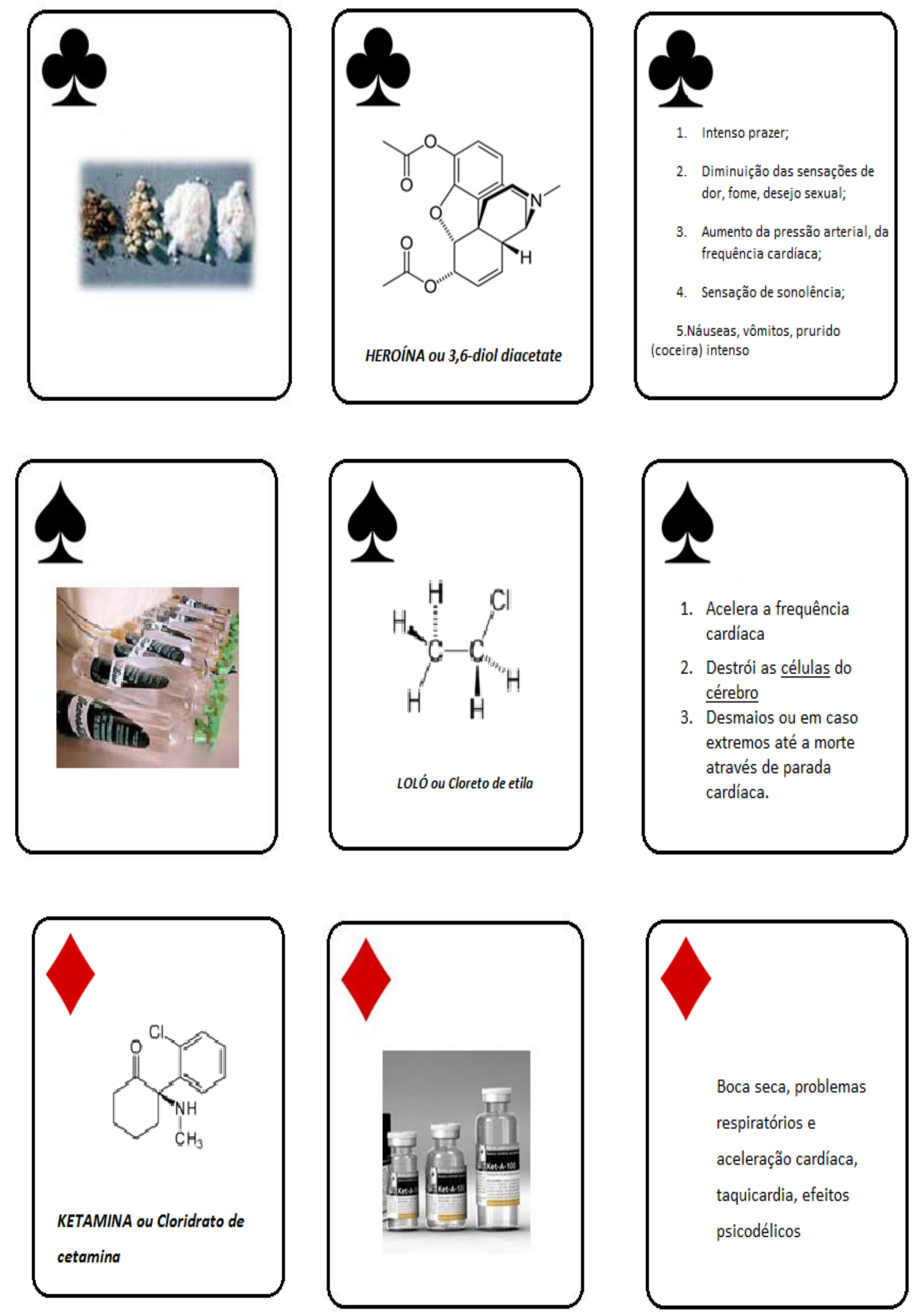

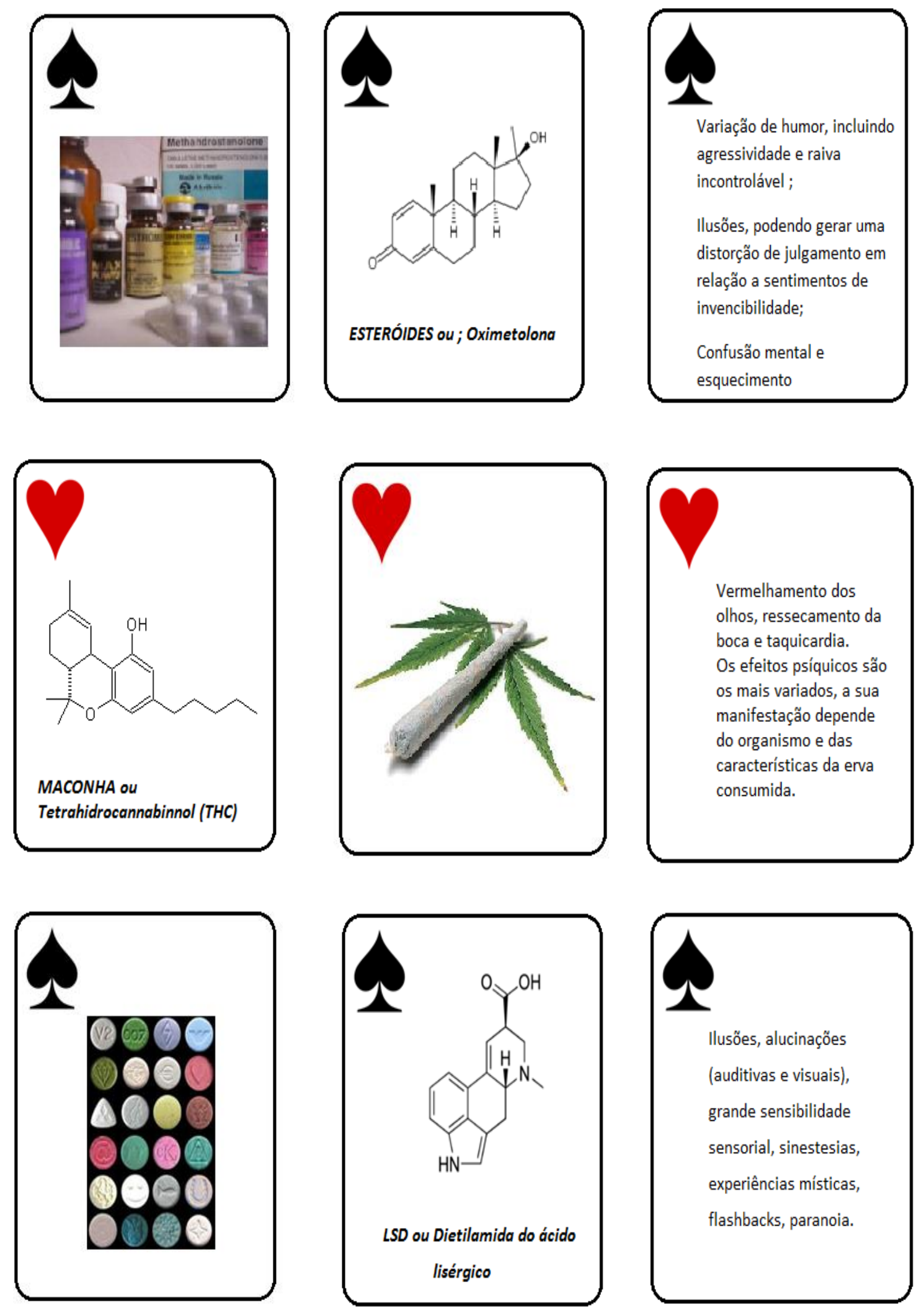

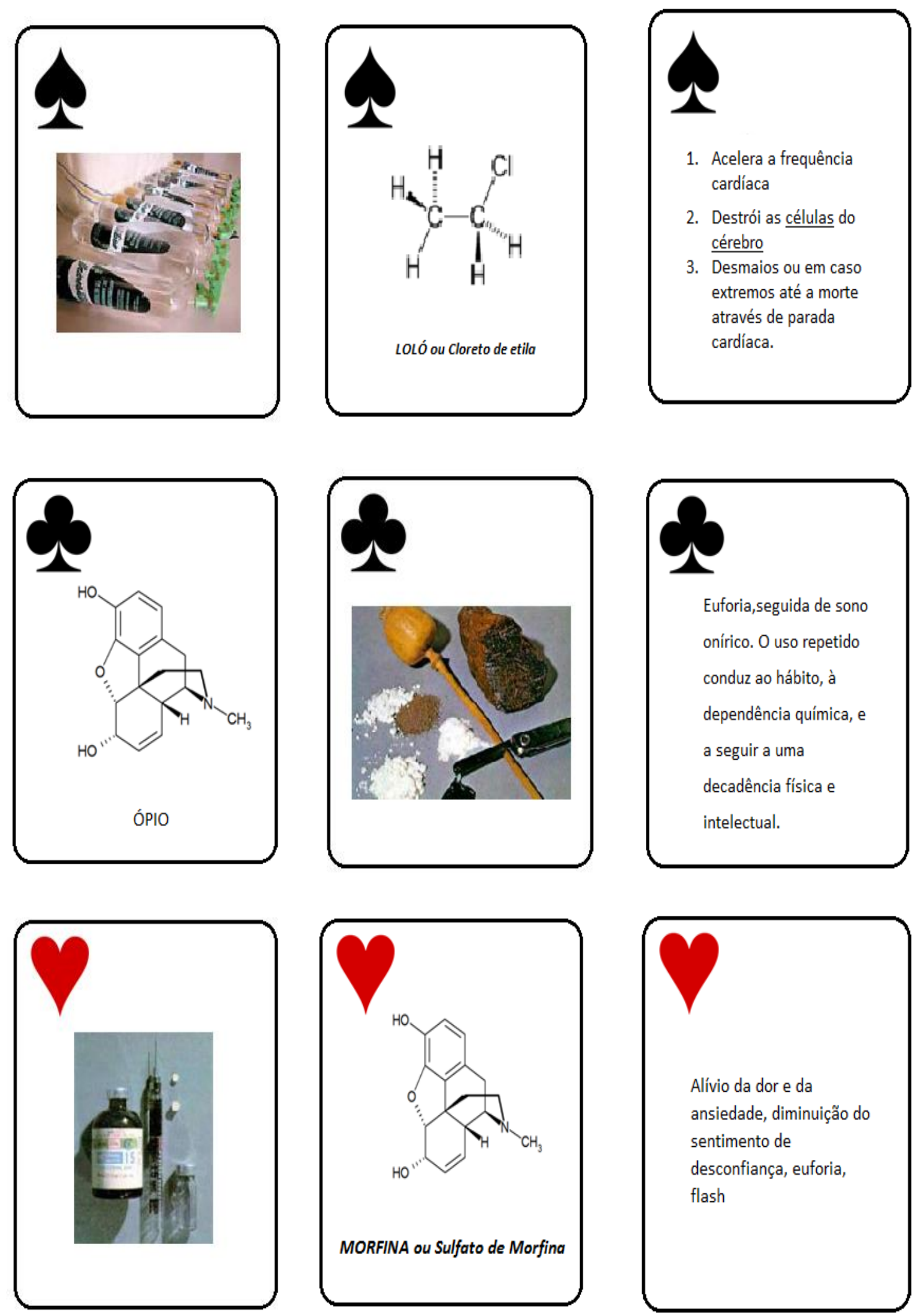


\section{Jogo \\ 11}

\section{Brincando e aprendendo sobre drogas de}

abuso

Marcos Antônio Furtado de Carvalho Filho; Marina Maciel de Oliveira Silva; Antônio Carlos Ferreira de Souza Filho; Priscila

Bezerra Falcão, Suzanne Alves Cordeiro; Verônica Bezerra Machado

\section{INTRODUÇÃO}

0 processo tradicional de ensino de Ciências, ora centrado em memorização e aplicação de formas para resoluções de questões, vem sendo aprimorado com alternativas lúdicas para potencializar a aprendizagem do aluno (MENDONÇA e LEITE, 2010).

Os professores encontram dificuldades para manter a atenção e o interesse dos alunos durante as aulas de Química, tornando assim, necessária a busca de métodos lúdicos que atraiam a concentração e desperte o interesse dos mesmos. Portanto é necessário direcionar os conteúdos de forma que os alunos possam relacionar com a sua vida diária, contextualizando-os a partir de seu cotidiano. Dessa maneira haverá um maior interesse pela descoberta de novos conhecimentos. Os jogos se caracterizam por dois elementos: o prazer e o esforço espontâneo, além de integrarem uma melhor interação dos alunos entre si, do aluno com o professor e principalmente do aluno com a disciplina. Com isso, infere-se que os jogos educativos constituem um importante recurso para o desenvolvimento do aprendizado na sala de aula.

O Grupo de Estudos sobre Drogas de Abuso do Curso de Licenciatura em Química da Universidade Estadual do Ceará (UECE) vem desenvolvendo jogos que aliam o ensino de Química com o assunto 'drogas' tão em evidência nos dias atuais pelos imensos prejuízos causados aos jovens principalmente, e à sociedade como um todo. Dados relativamente recentes na literatura indicam que tem ocorrido um aumento no consumo de drogas com potencial de abuso em crianças em idade escolar, e inclusive em idade pré-escolar, particularmente em meninos de rua (FRANCISCHI, 2005).

Com o objetivo de tornar o conhecimento sobre o assunto mais fácil de ser introduzido, foi criado o jogo "drogas, esse vício não", apresentado nesse trabalho que aborda a Química das drogas, preparando inclusive os professores no trato com assunto tão relevante. 

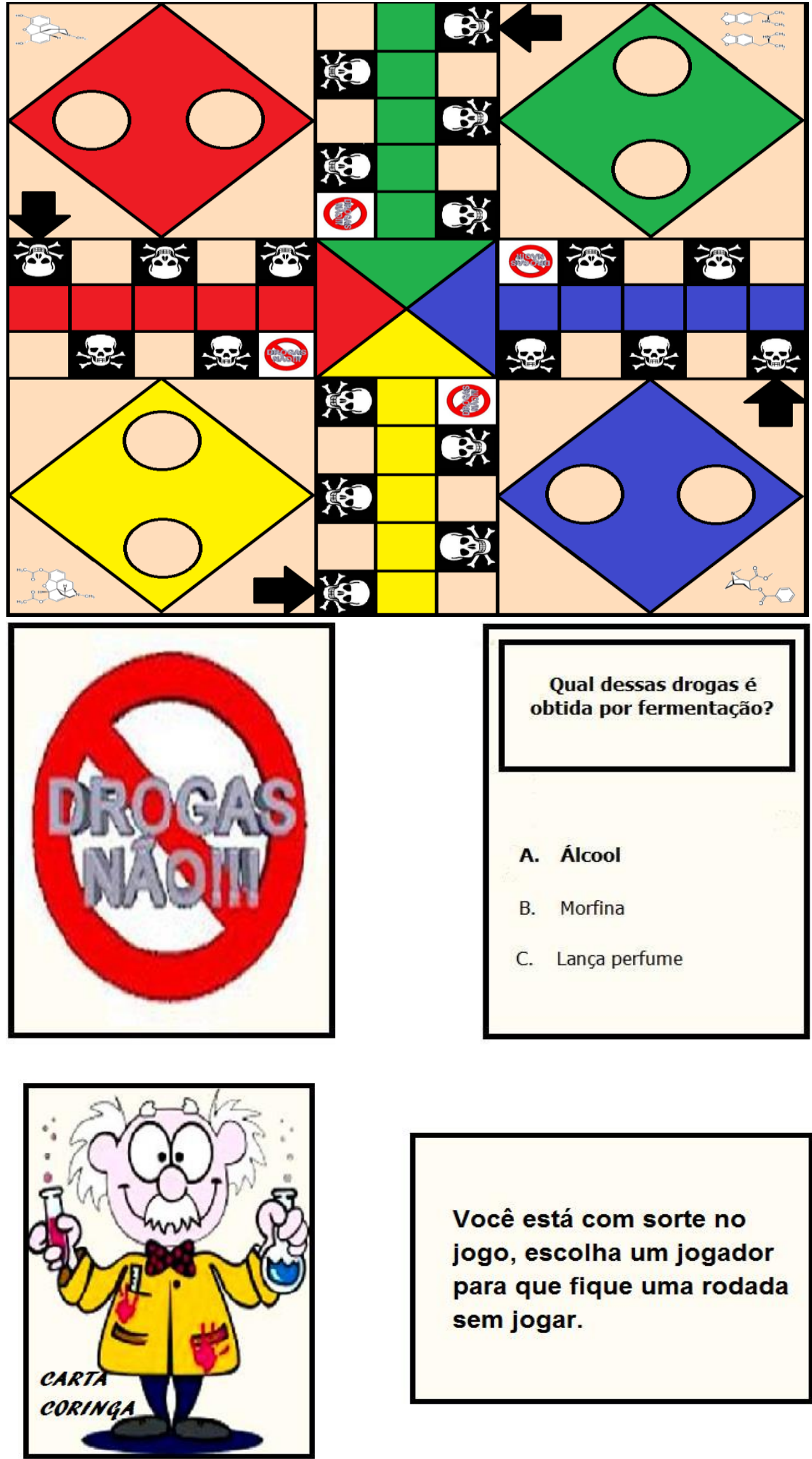

Você está com sorte no jogo, escolha um jogador para que fique uma rodada sem jogar. 


\section{Jogo \\ 17 Atos e Conseqüências \\ Luziane Rocha da Silva; Vanessa Cristina Silva Vasconcelos}

\section{INTRODUÇÃO}

O consumo de drogas aumentou muito no Brasil nos últimos anos, trazendo problemas para as famílias e para a sociedade. A introdução do assunto drogas em sala de aula pode ser feito de outra forma, através da utilização de jogos que podem criar uma nova relação, pois a escola é vista, pelos alunos como um meio de obtenção de um maior aprendizado tanto social como cultural.

Os jogos educativos têm por finalidade construir novas formas de pensamento, desenvolvendo e enriquecendo a personalidade de cada aluno, e para o professor, os jogos levam a condição de condutor, estimulador e avaliador de aprendizagem. 0 jogo elaborado é uma ferramenta indispensável no processo de ensino e aprendizagem e envolve tanto aspectos químicos como bioquímicos e tem o objetivo de informar de forma dinâmica e interativa as consequências do uso das drogas. A abordagem do cotidiano relacionando a Química e a sociedade vem sendo utilizada numa tentativa de despertar o interesse dos alunos por essa disciplina. 0 desenvolvimento de estratégias modernas e simples, utilizando experimentos, jogos e outros recursos didáticos, é recomendado para dinamizar o processo de aprendizagem em química. Os jogos estimulam a curiosidade, a iniciativa e a autoconfiança; aprimoram o desenvolvimento de habilidades linguísticas, mentais e de concentração; e exercitam interações sociais e trabalho em equipe (Vygotsky, 1989).

Os jogos têm uma relação íntima com a construção da inteligência, sendo uma ferramenta útil para o processo de motivação e para o aprendizado de conceitos. 0 jogo educativo tem como objetivo atrair os jovens para o perigo que as drogas causam no organismo, na vida de uma pessoa usando a química como disciplina de estudo. De acordo com uma pesquisa realizada pelo Centro Brasileiro de Informações sobre drogas psicotrópicas (Cebrid) da Unifesp, 57\% dos jovens entre 12 e 17 anos consideram que obter drogas em "qualquer momento" é "muito fácil". Em 2001, 48,3\% já tinham ingerido álcool; três anos depois, eram 54,3\%. O consumo de maconha também subiu: de 6,9\% em 2001, para 8,8\% em 2005. Muitos jovens acham "chato" falar sobre drogas, pois é um assunto delicado e de difícil abordagem. Com o jogo os alunos apreendem os conceitos de forma diferente e descontraída ocorrendo o conhecimento das drogas durante a aula de Química. 


\section{METODOLOGIA}

O jogo mostrado "Atos e Consequências" é composto por no máximo 3 pessoas. Ele é constituído de 2 dados e um tabuleiro, com 50 casas, sendo que algumas dessas casas serão encontradas surpresas tendo no tabuleiro uma casa referente ao início e outra a chegada. A estrutura do tabuleiro é feita com material resistente e cada caminho contém ilustrações relativas às drogas.

0 jogo flui no tempo total de 50 minutos, onde nos primeiros 10 minutos são feitos: distribuição dos peões de cada jogador, esclarecimentos sobre a temática do jogo, regras e objetivos, e o tempo restante será suficiente para que os participantes percorram todo o trajeto e respondam todas as perguntas, superando recuos, avanços e casas especiais. 0 jogador conta com o auxílio dos dados e das cartas, que trazem informações das drogas, como: tipo, efeitos, formula molécula e nomenclatura.

\section{RESULTADOS E DISCUSSÃO}

O objetivo desse jogo é criar uma nova relação entre aluno e disciplina. 0 jogo foi aplicado em um grupo de discentes do Curso de Licenciatura em Química da Universidade Estadual do Ceará (UECE) participantes do projeto "atos e consequências", os participantes concluíram que esse jogo será de máxima importância para a sua utilização nas atividades docentes. De forma geral os jogos apresentaram uma excelente aprendizagem na disciplina, dando ao aluno motivação para o estudo da química. Foi observado que o assunto gerou interesse e curiosidades pelos alunos, tornando a aprendizagem ao final satisfatória. Também foi possível perceber que houve uma socialização entre os alunos, tornando-os mais aptos a absorverem os assuntos em sala de aula.

\section{CONCLUSÃO}

Com a elaboração deste trabalho, foi observado que os alunos tiveram uma participação ativa no seu processo de aprendizagem e crescimento pessoal, uma vez que a cooperação melhora a eficácia da ação pedagógica. Deve-se ressaltar a conscientização para o não uso de drogas. 


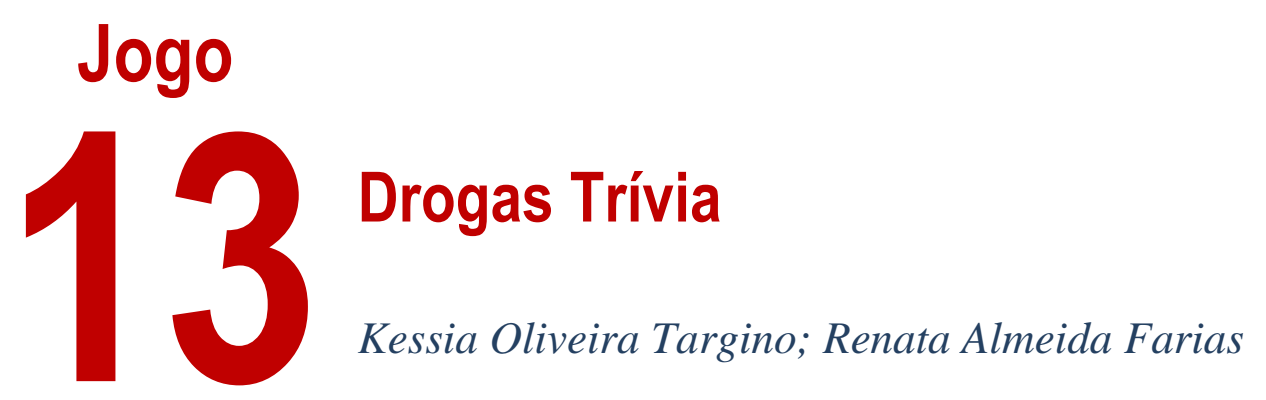

\section{INTRODUÇÃO}

0 ingresso na universidade, ainda que traga sentimentos positivos e de alcance de uma meta programada por estudantes do ensino médio, por vezes pode se tornar um período crítico, de maior vulnerabilidade para o início do uso de álcool e outras drogas. 0 consumo de drogas continua a crescer e é considerado um problema de saúde pública devido aos seus efeitos nocivos, o que preocupa a comunidade brasileira. 0 uso de drogas em universidades é um ato comumente praticado. No Brasil, existem 2.377 Instituições de Ensino Superior, das quais 278 são públicas e 2.099 privadas, distribuídas nos 26 Estados brasileiros e Distrito Federal. Em 2010, foi publicado o I Levantamento Nacional sobre o Uso de Álcool, Tabaco e outras Drogas entre Universitários de 27 Capitais Brasileiras, onde se observou um grande abuso das drogas pelos alunos. Devido a esse fato foi fabricado um jogo "Drogas Trívia" com objetivo de levar conhecimento sobre drogas aos universitários, pois com a consciência sobre como funciona, é produzido e quais os efeito destas a curto e a longo prazo, assim o jogo será um instrumento de prevenção para esses alunos que estão iniciando sua vida adulta.

O jogo "Drogas Trívia" é repleto de perguntas que desafiam o conhecimento e traz diversas curiosidades e explicações sobre as drogas lícitas e ilícitas aos estudantes do ensino Superior. No jogo "Drogas Trívia" há quatro categorias que são representadas por figuras, e cada uma deles tem um significado: História das Drogas, Química das Drogas, Drogas ilícitas, Drogas licitas e o competidor só ganhará se conseguir as quatro figuras que representam cada uma das categorias.

O jogo foi empregado em discentes da Universidade Estadual do Ceará, e após a aplicação do jogo, foi entregue um questionário quantitativo e objetivo, onde $100 \%$ dos alunos responderam que o jogo contribui na prevenção contra as drogas e que lhes ajudou a terem maior entendimento sobre as mesmas, 91,7\% afirmaram gostar do jogo e que jogariam novamente, já $83,3 \%$ dos discentes responderam que o jogo contribuiria para manter os estudantes longe das drogas, que auxiliou a compreenderem a química existente na produção de tais substancias e que eles indicariam o jogo aos amigos. Também foi verificado que 66,7\% já usaram algum tipo de droga lícita e que 33,3\% usaram drogas ilícitas, sendo que só $25 \%$ dos alunos receberam algum tipo de orientação em casa. E a partir das respostas obtidos concluiu-se que o jogo educativo sobre drogas é uma ótima forma de abordar o assunto em sala de aula, uma vez que a maioria dos jogadores não tem orientações em casa, e de levar conhecimento para os estudantes universitários fazendo uma prevenção. 
Figuras que deverão ser conquistadas pelos jogadores:

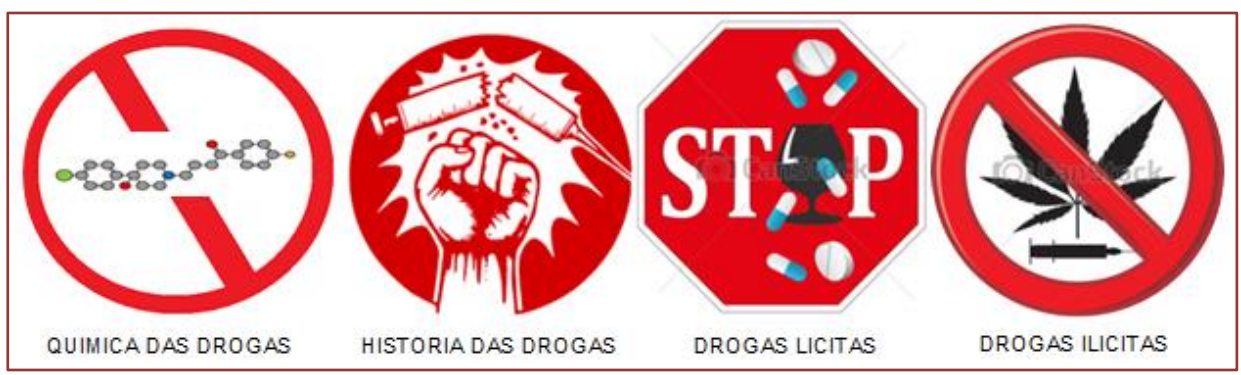

Figura 2: Imagem para fazer por na roleta

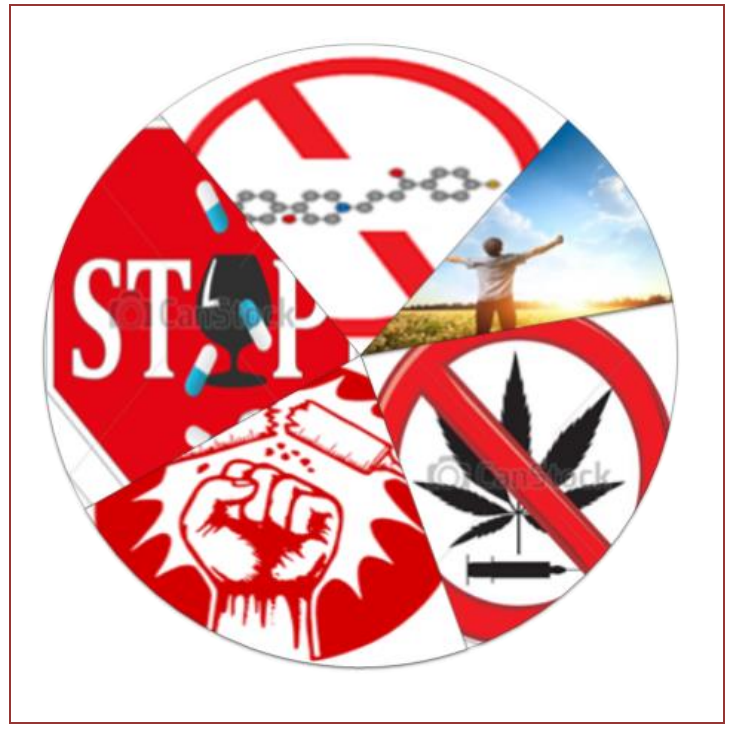

O jogo Drogas Trívia é repleto de perguntas que desafiam o conhecimento dos alunos de ensino Superior, em uma das quatro categorias do jogo, que estão divididas em: História das Drogas, Química das Drogas, Drogas ilícitas, Drogas licitas. Ganha quem primeiro conseguir as quatro figuras que representam cada uma das categorias.

\section{MODO DE JOGAR}

Jogo feito para dois ou mais jogadores. Primeiramente, roda-se a roleta. E o jogador responderá uma pergunta dependendo da categoria em que se caia. Caso acerte a primeira pergunta, rodará a roleta novamente, para ter a chance de responder a segunda pergunta, se acertar terá conquistado uma das figuras das categorias que o participante escolher, ficando na frente dos seus oponentes. Os jogadores faram isso até que um jogador consiga todas as figuras, assim ganhando o jogo. E caso o oponente erre a pergunta, ele perde a vez e não obter a figura correspondente à categoria. E se ao girar a roleta, o participante tirar a Liberdade das drogas, ele imediatamente, terá o direito conquistado uma figura e terá o direito a rodar novamente a roleta podendo pegar outras figuras. Quem obter todas as figuras ganha a liberdade total das drogas. Ganhando o jogo.

Seja rápido para pensar, depois de girar a roleta você tem apenas 20 segundos para responder à pergunta no jogo Drogas Trívia. 


\section{PERGUNTAS E RESPOSTAS DO JOGO}

0 jogo é muito interessante pois apresenta figuras que representam as categorias, é rápido e possui mais de 100 perguntas.

As questões estão separadas por áreas (exemplo: se o jogador 1 tirar na roleta no assunto química das drogas, ele deverá responder uma questão dessa área). 0 símbolo * indica a resposta correta. E algumas das questões possuem curiosidades, para aumentar as informações dadas aos jogadores. 


\section{ANEXOS}

\section{Qual é a droga ilícita mais consumida habitualmente?}

- Maconha*

- Heroína

- Ecstasy

- Cocaína

\section{Qual destas afirmações é verdadeira?}

- As drogas melhoram a criatividade da pessoa

- Pode ser que uma droga dê uma "euforia" temporária, mas quando o efeito passa, o "bode" é uma sensação muito pior do que antes*

- As drogas afastam os medos e fazem com que a vida seja mais agradável

- Demora anos para que uma pessoa fique dependente de drogas

3.A maioria dos dependentes químicos dizem ter se viciado em qual droga após usar pela primeira vez?

- LSD

- Ecstasy

- Maconha*

- Metanfetamina

\section{De onde vem a maconha?}

- De uma raiz

- De um produto químico

- De uma planta*

- De um cogumelo

8.Como o uso de maconha pode levar a drogas mais pesadas?

- As pessoas que fumam maconha tendem a experimentar outras drogas

- Os usuários de maconha precisam de outras drogas para aumentar os efeitos da erva

- Como os usuários de maconha tendem a criar tolerância a essa droga, a pessoa procura drogas mais fortes para ter os mesmos efeitos. *

- Uma forma de tratar a dependência de maconha é usar outras drogas 


\section{0 que faz o ecstasy ser perigoso?}

- É feito em laboratórios caseiros sujos

- Nunca se sabe realmente o que a droga contém*

- As cores diferentes que a droga possui podem confundir alguém

- Faz com que os usuários dancem a noite toda

18.Por que os usuários de ecstasy correm o risco de morte por desidratação?

- Porque a droga mascara os sinais de alerta naturais do corpo que indicariam à pessoa que ela está desidratada*

- Porque eles dançam demais depois de consumirem a droga

- Porque eles não fazem intervalos suficientes para sair e tomar ar fresco

- A droga impede o corpo de absorver água

\section{Quais são alguns dos efeitos a curto prazo causados pelo ecstasy?}

- Ranger involuntário dos dentes, falsa sensação de afeto, paranoia, confusão e visão embaçada*

- Aumento de apetite, uma maior percepção de si mesmo, força física aumentada e maior resistência às doenças

- Clareza mental melhorada e bom discernimento

- Músculos relaxados e uma paz interior

20.Quais são alguns dos efeitos a longo prazo causados pelo ecstasy?

- Sangramento nasal

- Mal estar estomacal

- Perda de memória e danos cerebrais permanentes*

- Danos pulmonares

\section{Usar crack uma vez pode:}

- Causar dependência

- Aumentar os batimentos cardíacos, causar espasmos musculares e convulsões

- Causar uma depressão profunda

- Causar todo o mencionado acima*

\section{0 crack é ainda mais perigoso que a cocaína por causa de:}

- Muitas vezes ser misturado com outras substâncias perigosas

- Ser inalado ou fumado e ter 75 a 100\% de pureza*

- Causar dependência 
- Ser natural

\section{Um usuário de crack:}

- Pode levar uma vida normal

- Tem de usar quantidades cada vez maiores da droga e mais frequentemente só para se sentir "normal"*

- Pode aprender a viver com o problema

- Tem relacionamentos mais longos

\section{Alguns efeitos do crack a curto prazo são:}

- Um barato de longa duração

- Perda de cabelo

- Um interesse renovado pela vida

- Sensação de paranoia, ira e nervosismo.*

\section{Alguns dos efeitos do crack a longo prazo são:}

- Depressão profunda*

- Aumento de consciência

- Queda de cabelo permanente

- Pele escamosa

\section{Que aspecto tem o cristal de metanfetamína?}

- Pequenos fragmentos que se parecem com vidros ou pedras azul-esbranquiçadas brilhantes*

- Comprimidos azuis com desenhos

- Um pó branco que parece farinha

- Uma planta com folhas azul-esverdeadas

\section{Quais são os nomes populares da metanfetamína?}

- $\quad$ Speed, Crank, Tina e Ice*

- Pedra, Base Livre, Branquinha, Bala

- Baseado, Birita, Pílula do Amor

- Doce, Cola, Gás, Pontos

75.Sobre o efeito da maconha é correto afirmar que:

- Podem variar de acordo com as características do usuário. Pode afetar atividade locomotora, humor, memória e pulmões. Substância pode ser usada com fins terapêuticos para tratar câncer e HIV. * 
- Podem variar de acordo com as características do usuário. Pode causar inúmeras doenças, além de não trazer nenhum benefício, tem um custo absurdo para o país, sendo totalmente ilegal em todos os países.

- Causa dor de barriga, problemas psíquicos intensos, dor nas articulações, dor nas pernas e ligeira impressão de dormência.

- Causa sensação de equilíbrio em todos os casos ao usuário, além de ativar regiões peculiares no corpo humano.

Os efeitos do uso da maconha no organismo podem variar de acordo com as características do usuário.

33.Qual é a quantidade necessária de metanfetamína para fazer uma pessoa ficar dependente?

- $\quad$ Entre dez e vinte vezes

- As pessoas podem usar metanfetamína tanto quanto quiserem e nunca ficarão dependentes

- São necessários três meses de uso regular para que a pessoa fique dependente

- Uma pessoa pode ficar dependente de metanfetamína na primeira vez que a usa*

34.Quais são alguns dos efeitos a curto prazo causados pela metanfetamína?

- Distúrbios do sono, hiperatividade e alucinações*

- Grande alegria e uma maior confiança nos outros

- Asma e problemas digestivos

- Sede constante

\section{Quais são alguns dos efeitos a longo prazo causados pela metanfetamína?}

- Ossos frágeis e fraqueza muscular

- Dores de cabeça e aumento do apetite

- Gripes e alergias

- Lesões cerebrais e colapso cardíaco e dos vasos sanguíneos*

36.Algumas das formas como os inalantes afetam o corpo são:

- Perda de cabelo e cáries

- Os batimentos cardíacos são mais lentos e mais regulares

- Aumenta o tônus e força musculares

- Perda do olfato, náusea e sangramento do nariz, assim como problemas hepáticos, pulmonares e renais* 
37.0 que acontece com a frequência cardíaca de uma pessoa após a inalação de produtos químicos perigosos?

- Fica lenta

- Não é afetada de jeito nenhum e não muda

- É mais irregular e mais rápida*

- É mais regular

38.0 que estes inalantes causam ao cérebro?

- Faz com que se derreta ou dissolva

- Faz com que se inche*

- Causa lesões no tecido cerebral

- Faz com que diminua

\section{Como se usa heroína?}

- Oralmente, por meio de comprimidos

- É injetada, inalada ou fumada*

- É ingerida com a comida

- Por prescrição médica

\section{0 que a heroína faz quando entra no cérebro?}

- Faz com que uma pessoa pense mais rápido

- Faz com que a pessoa seja mais capaz de resolver problemas

- Faz com que uma pessoa pense e reaja lentamente*

- Faz com que as pessoas se lembrem de coisas das quais se tinham esquecido

43.Além dos perigos da própria droga, quais são os outros riscos do uso de heroína?

- Contrair HIV, hepatite (doença do fígado) e outras doenças a partir de agulhas infectadas

- Reações alérgicas à droga, incluindo coceiras

- Transmitir uma doença contraída a parceiros sexuais ou recém-nascidos

- A primeira e a terceira respostas*

44.Quais são alguns dos efeitos a curto prazo causados pela heroína?

- Agilidade mental aumentada

- Gripes e dores de cabeça

- Aborto espontâneo em mulheres grávidas* 
- Desejo por comidas doces e salgadas

45.Quais são alguns dos efeitos a longo prazo causados pela heroína?

- Energia aumentada

- Veias colapsam e ocorrem infecções dos tecidos moles*

- Perda de visão

- Cabelos brancos prematuros

46.Do que é feito o LSD?

- De um fungo*

- De uma planta frondosa

- De detergentes domésticos

- Do trigo

47.Quanto tempo duram os efeitos do LSD?

- Três horas

- Uma hora

- Doze minutos

- Doze horas ou mais*

49.Quais são alguns dos efeitos a curto prazo causados pelo LSD?

- Pensamentos aterrorizantes graves, medo de perder o controle, medo de insanidade e da morte*

- Aumento do apetite e diminuição da temperatura corporal

- Energia física e resistência aumentadas

- Um estado semelhante a um morto-vivo

50.Quais são alguns dos efeitos a longo prazo causados pelo LSD?

- Psicose de longa duração*

- Depois que o efeito da droga desaparece já não existem outros efeitos

- Ira e agressão

- Obesidade e diabetes

103.Qual é a droga ilícita mais consumida no Brasil?

- Anfetamina

- Maconha*

- Cocaína

- Êxtase 
O uso da maconha é especialmente popular entre os estudantes do ensino médio e jovens adultos. Cerca de $22 \%$ dos brasileiros acima dos 18 anos já usaram drogas, além do álcool e do cigarro.

109. Diga 3 “apelidos" para a maconha.

- Baseado, erva e haxixe

110. Diga 3 “apelidos” para cocaína.

- Crack, pó, perda, branquinha e nuvem.

\section{Diga 3 drogas que funcione como estimulantes.}

- Anfetamina, rebite, ecstasy, bolinhas

\section{Sobre a Química das drogas}

\section{0 que se quer dizer com "tolerância" à droga?}

- A pessoa tem uma fissura contínua pela droga

- Dar às pessoas a escolha de usarem quaisquer drogas que quiserem

- É necessário cada vez mais droga para produzir o mesmo barato*

- Um desejo para experimentar novos tipos de drogas

5.Quais são alguns dos sintomas da dependência química?

- Aumento do ritmo cardíaco

- Depressão e fissura por mais droga*

- Perda de apetite

- Flashbacks

\section{Qual das afirmações abaixo é verdadeira?}

- A maconha faz com que as pessoas fiquem mais dispostas para aprender

- A maconha contém mais de 400 produtos químicos*

- A maconha ajuda os atletas a terem melhores resultados nos esportes

- O uso de maconha aumenta as oportunidades que um estudante tem para passar nas provas

\section{Alguns efeitos da maconha a curto prazo são:}

- Perda da coordenação e distorções do sentido de tempo, visão e audição*

- O desempenho escolar é aumentado devido a uma memória melhor e maior capacidade para resolver problemas

- Diminuição do risco de ataque cardíaco

- Melhor resistência e desempenho físico em competições 


\section{Alguns efeitos da maconha a longo prazo são:}

- Resistência à gripe e resfriados comuns

- Danos nos pulmões e no coração*

- Aumento da produtividade e sensação de realização

- Anorexia e perda de peso

\section{Qual é a diferença entre cocaína e crack?}

- A cocaína é uma variante de crack

- São exatamente o mesmo em todos os aspectos

- Não há nenhuma diferença

- A cocaína é a droga na forma de pó e o crack é a mesma droga na forma de cristal*

22.De onde vem a cocaína?

- De uma planta*

- É feita em laboratório

- De um cogumelo

- De uma pedra

\section{0 que acontece quando a "euforia" gerada pela cocaína passa?}

- Não acontece nada

- A pessoa fica realmente cansada

- A pessoa fica profundamente deprimida e pode cometer suicídio*

- A pessoa se sente feliz e calma

\section{Quais são alguns dos efeitos a curto prazo causados pela cocaína?}

- Paranoia, ira, hostilidade e ansiedade, mesmo quando a pessoa não está sob o efeito da droga*

- Sono agitado

- Felicidade intensa

- Diminuição dos batimentos cardíacos e tônus muscular aumentado

\section{Quais são alguns dos efeitos a longo prazo causados pela cocaína?}

- Obesidade e pressão alta

- Irritabilidade, paranoia e alucinações auditivas*

- Sensação constante de frio e o nariz escorre constantemente

- Maior fertilidade 
40.Alguns dos efeitos da inalação de produtos químicos a longo prazo são:

- Aumento de tônus e força musculares

- Ganho de peso e obesidade

- Tônus e força musculares diminuídas*

- Maior sensação de equilíbrio

\section{Como uma pessoa reconhece o LSD?}

- Cada quadradinho da cartela tem personagens de desenhos animados

- 0 LSD é muitas vezes misturado com papel absorvente e dividido em quadradinhos decorados*

- Parece-se com pedaços de vidro ou pedrinhas

- É um pó verde brilhante

77. Quanto tempo o ecstasy demora para chegar ao cérebro?

- $2 \mathrm{~min}$

- $15 \mathrm{~min}$

- Cerca de $1 \mathrm{~h}$

- $24 \mathrm{~h}$

39.Alguns efeitos da inalação de produtos químicos a curto prazo são:

- Morte por ataque cardíaco ou asfixia*

- Olfato mais apurado e visão mais precisa

- Aumento de apetite e músculos relaxados

- Aumento da energia física e mental

79.Qual é a principal substância psicoativa na maconha?

- Dietilamida do ácido lisérgico

- Delta-9-tetra-hidrocanabinol*

- 4-fosforiloxi-N

- 3,4-Metilenodioxianfetamina

A principal substância psicoativa da maconha é o delta-9-tetra-hidrocanabinol (THC). Ele é encontrado na resina produzida pelas folhas e pelos brotos da cannabis 
88.0 que são "drogas"? Todas atuam da mesma forma?

- É todo e qualquer composto químico, natural ou sintético, que após ser introduzido no corpo animal provoca mudanças na sua funcionalidade, alterando atividades fisiológicas ou comportamentais. *

- É toda substância química, natural ou produzida pelo homem, que proporciona mudanças especificamente no sistema nervoso central (SNC).

- É qualquer substância química que altera a o comportamento animal, deixando sempre o indivíduo agressivo. Justifique a resposta.

- São moléculas que, ao serem introduzidas no organismo, provocam sensação de euforia, mas não tem o poder de viciar o usuário.

As drogas podem ser de origem natural ou sintética e, quando introduzido em um animal pode provocar mudanças funcionais, no comportamento e fisiologia.Podendo ter ação em diversos tipos de neurotransmissores no SNC.

\section{0 que sabemos sobre drogas psicotrópicas?}

- São drogas que atuam alterando o comportamento, humor, cognição e agem diretamente no sistema nervoso periférico (SNP).

- São drogas que agem no SNC proporcionando sempre sensação de euforia, em qualquer pessoa.

- São drogas que agem no SNC, alterando o comportamento, a cognição, o humor e apresentam propriedade reforçadora, induzindo à auto-administração (Organização Mundial da Saúde, 1981). Por tanto, aumentam as chances de dependência.*

- NDA

\section{Como as drogas psicotrópicas agem no SNC?}

- Atuam impedindo a comunicação inter neuronal, interferindo na produção do impulso nervoso.

- Atuam aumentando a quantidade de impulso nervoso entre os neurônios.

- Essas drogas alteram a química cerebral, interferindo nas atividades normais dos neurotransmissores, que são as moléculas responsáveis pela comunicação química entre os neurônios. Cite um exemplo de neurotransmissor.*

- NDA 
A sua ação ocorre pela interferência na atividade normal dos neurotransmissores através das sinapses.

\section{0 que você entende por Sistema de Recompensa?}

- O sistema de recompensa, também denominado de sistema dopaminérgico, é o sistema de comunicação neuronal que participa da busca por prazer. 0 neurotransmissor envolvido nessa comunicação entre os neurônios présinápticos e pós-sinápticos é a dopamina.*

- É um sistema de comunicação entre neurônios que atua aumentando o nível de neurotransmissores nas fendas sinápticas e são responsáveis pelas sensações de dor e sofrimento.

- É uma rede de comunicações sinápticas que agem alterando a química cerebral devido ao uso de qualquer tipo de droga, esta sendo ou não psicotrópica.

- NDA

É também essa molécula responsável pelas sensações de prazer, o que sentimos quando fazemos atividades satisfatórias como comer uma comida gostosa, quando sentimos um cheiro agradável de um perfume ou quando fazemos sexo, por exemplo.

92.Sobre o que aprendemos até o momento, qual neurotransmissor é responsável pela dependência das drogas de abuso?

- Noradrenalina

- Dopamina*

- Endorfina

- Serotonina

- NDA

As drogas de abuso agem no neurônio dopaminérgico, induzindo um aumento brusco e exacerbado de dopamina no núcleo accumbens, mecanismo comum para praticamente todas as drogas.

\section{0nde são produzidos os neurotransmissores?}

- Pericário ou corpo celular.*

- Dentritos (terminação da recepção).

- Axônios (terminação da transmissão).

- Ribossomos 
94.Sobre o neurotransmissor GABA, escolha a afirmativa correta.

- É o principal neurotransmissor inibitório do encéfalo.*

- Esse neurotransmissor está relacionado a excitação físico e mental, bem como é conhecido por promover o bom humor.

- Controla níveis de estimulação e controle motor em muitas áreas do SNP.

- NDA

O processo inibitório ocorre quando o GABA se liga ao receptor, permitindo dessa forma a entrada de Cloro para dentro da célula.

87.0 que é feito pelo homem, deixa doidão, mas também pode deixá-lo paranoico, produzir alucinações e normalmente carrega o rótulo de "não é para consumo humano"?

- Esteroides anabolizantes

- Sais de banho*

- Sálvia

- Metanfetamína

"Sais de banho" é o termo comumente usado para catinonas sintéticas (feitas pelo homem), um estimulante tipo anfetamina. Elas pertencem a um grupo de drogas as quais os especialistas se referem como "novas substâncias psicoativas".

97.Sobre o neurotransmissor glutamato, indique a opção correta.

- Sua deficiência causa Desordem obsessiva compulsiva.

- Seu excesso está ligado ao mal de Alzheimer.

- Está ligado a doença de Parkinson causando degeneração de neurônios glutamáticos oriundos da substância negra, que enviam as suas projeções para o estriado, o qual está envolvido no controle motor do movimento.

- O glutamato é o neurotransmissor excitatório mais importante do cérebro humano, parecendo ter um papel crítico na memória e cognição.*

107. 0 Álcool além de ser uma droga é também uma função orgânica, que é representada por;

- $-\mathrm{OH}$

- $-\mathrm{COOH}$

- $-\mathrm{NH} 2$

- $-\mathrm{CH} 3$ 
112. 0 bicarbonato de sódio $\left(\mathrm{NaHCO}_{3}\right)$ é utilizado na fabricação de qual droga ilícita?

- Maconha

- Heroína

- Ecstasy

- Crack* $^{*}$

113. Na composição do ecstasy há presença de uma amina secundário, sabendo disso qual seria o nome da substancia que compõe essa droga.

- 3,4-metilenodioximetanfetamina*

- Tetrahidrocanabinol

- Dimetiltriptamina

- Meprobamato

Sobre as drogas lícitas

11.Por que o álcool é mais prejudicial para os adolescentes do que para os adultos?

- Porque eles têm a tendência para beber mais

- Porque seus corpos ainda estão em fase de crescimento*

- Porque são menores de idade

- Porque legalmente não podem entrar em bares

12.Uma mulher grávida que toma álcool é provável que:

- Tenha uma gravidez difícil

- Tenha gêmeos

- Dê à luz um bebê com deficiências faciais, crescimento retardado e danos cerebrais*

- Se divorcie

\section{Quando o álcool é tomado com outras drogas:}

- Diminui os efeitos de outras drogas

- É extremamente perigoso e pode ser fatal*

- Diminui os efeitos do álcool

- Faz com que os efeitos de outras drogas durem mais 
14.Alguns efeitos do consumo de álcool a curto prazo são:

- Perda de discernimento e coordenação, fala arrastada, perda de memória e compreensão*

- Maior autoestima e autocontrole

- Percepções mais apuradas e tempo de reação mais rápido

- Desinibição para conversas

15.Alguns dos efeitos do consumo de álcool a longo prazo são:

- Uma abordagem calma e realista da vida

- Danos no fígado e aumento do risco de doença cardíaca*

- Obesidade ou perda de peso extrema

- Cabelo oleoso ou calvície

17.Quão perigoso é consumir ecstasy junto com álcool?

- Há um risco maior de asfixia

- Pode fazer você vomitar

- Pode fazer você adormecer

- Pode ser mortal*

51.0 que pode acontecer se se tomar sedativos ou tranquilizantes com álcool?

- Terá como resultado um barato mais prolongado

- Uma pessoa pode ter dificuldades para dormir

- Pode diminuir os batimentos cardíacos e a respiração e até mesmo levar à morte*

- Pode causar períodos de perda de memória

53.Qual é um dos maiores perigos dos analgésicos e drogas similares?

- Um dos ingredientes é venenoso

- Os usuários continuam a tomá-los enquanto os comprimidos anteriores ainda estão causando efeitos*

- Podem causar náusea

- Nunca se sabe com que pode ter sido misturado

54.Por que algumas drogas são chamadas de "calmantes"?

- Porque ajudam uma pessoa a sair da depressão

- Porque acabam levando à depressão

- Porque é o oposto dos antidepressivos

- Porque reduzem a velocidade das funções cerebrais e do sistema respiratório* 
55.Quais são alguns dos efeitos colaterais dos antidepressivos?

- Perda de peso

- Temperatura corporal elevada

- Pensamentos e ações violentos ou suicidas*

- Danos no fígado ou pulmões

56.Que analgésico contém oxicodona?

- OxyContin

- Percocet

- Morfina

- A primeira e a segunda respostas*

57.Qual das seguintes afirmações é verdadeira?

- É completamente seguro tomar drogas de prescrição médica

- Oxicodona causa dependência*

- Não tem como uma pessoa ficar dependente de analgésicos

- Os analgésicos não são drogas, são medicamentos

58.Quais são alguns dos efeitos dos analgésicos a curto prazo?

- Não existem efeitos a curto prazo

- Pressão alta

- Prisão de ventre, sedação, vômitos e fraqueza*

- Ataque cardíaco e derrames

59.Qual é o efeito dos analgésicos a longo prazo?

- Dependência química*

- Insuficiência cardíaca

- Câncer

- Ossos frágeis

60.Por que a Ritalina é usada abusivamente?

- Devido aos seus efeitos calmantes

- Porque é uma droga prescrita pelo médico

- Devido aos seus efeitos estimulantes*

- Ajuda os estudantes a se concentrarem nos exames 
61.Quais são alguns dos nomes populares da Ritalina?

- M\&Ms, Doce, Pedra, Dona Juanita

- Skittles, Smarties, Vitamina R, Coca Diet*

- Farinha, Rebite, Pedra

- Cristal, Pó, Rush, Speed

\section{Por que o uso abusivo de Ritalina é perigoso?}

- As crianças que a consomem têm duas vezes mais probabilidades de usar drogas ilícitas

- Grandes doses causam pressão no coração e isso pode ser fatal

- Pode causar anormalidades genéticas

- Todo o mencionado acima*

\section{Quais são alguns dos efeitos a curto prazo da Ritalina?}

- Danos nos pulmões e nos olhos

- Alucinações visuais, pensamentos suicidas e comportamento violento

- Dificuldade em responder perguntas de múltipla escolha

- A primeira e a segunda respostas*

64.Quais são alguns dos efeitos da Ritalina a longo prazo?

- Ganho de peso e colesterol elevado

- Danos irreversíveis nos vasos sanguíneos coronários e cerebrais, acidente vascular cerebral e epilepsia*

- Maior clareza mental e desempenho acadêmico

- Abnegação

95.Sobre os efeitos do álcool no SNC com 0.18 - 0.30 de concentração no sangue, marque a alternativa correta.

- Comportamento sem alterações.

- Desorientação, confusão mental e adormecimento*

- Euforia leve, sociabilidade, indivíduo torna-se mais falante.

- Temperatura corporal abaixo do normal

Nesta concentração, dependendo do peso corporal, idade e sexo da pessoa, podem ocorrer uma grande desorientação espacial,dificuldade em interpretar informações e uma maior sonolência. 


\section{Qual tipo de ação o álcool proporciona ao SNC?}

- Ação estimulante.

- Ação inibitória.

- Ação recreativa.

- Ação depressora.*

\section{0 que queremos dizer por abuso de medicamentos prescritos?}

- Tomar um medicamento que não foi prescrito para você

- Tomar um medicamento em uma dosagem diferente da que foi prescrita

- Usar um medicamento por um motivo daquele para que foi receitado

- Todos os itens acima*

Medicamentos para a dor, ansiolíticos e estimulantes estão entre os medicamentos mais comumente abusados.

102.0casionalmente, fumar um cigarro ou dois é inofensivo. Verdadeiro ou falso?

- Verdadeiro

- Falso*

Especialistas em saúde enfatizam que não há nível seguro de consumo de tabaco. Basta estar perto de fumantes que é prejudicial para sua saúde. 0 tabagismo passivo é a 3ạ . maior causa de morte evitável do mundo. No Brasil, estima-se que cerca de 290 mil mortes por ano são decorrentes do tabagismo.

106.É possível dirigir bem depois de ter ingerido apenas uma bebida alcoólica. Verdadeiro ou falso?

- Verdadeiro

- Falso*

Falso. Até mesmo um copo de álcool prejudica o tempo de reação e julgamento. Você nunca deve beber e dirigir.

104.0 álcool é a forma mais comum de dependência química no Brasil. Verdadeiro ou falso?

- Verdadeiro*

- Falso

Verdadeiro. Apesar da dependência de nicotina do tabaco ser muito prevalente entre os brasileiros (10,1\%), a dependência do álcool é a mais prevalente em nossa população $(12,3 \%)$. 
105.Mortes por intoxicação de drogas são mais comuns entre adultos com menos de 35 anos de idade. Verdadeiro ou falso?

- Verdadeiro

- Falso*

Mortes por intoxicação de drogas são mais comuns entre as idades de 45 e 54 anos do que em outras faixas etárias.

108. Diga 3 formas de usar o tabaco.

- Cigarro, cachimbo e charuto.

Sobre a História do uso das drogas

52.Por que o Rohypnol tem a fama de ser "a droga do estupro"?

- A pessoa que o toma perde o controle muscular e sofre de confusão mental, fazendo com que seja incapaz de resistir*

- Porque é frequentemente usado por estudantes universitários em encontros

- As pessoas que o usam perdem suas inibições

- Faz uma pessoa ficar mais agressiva

65.0 Rohypnol tem a fama de ser a droga do:

- Sono

- Agressividade

- Estupro*

- Blecaute

66.A Maconha é uma planta herbácea de clima quente, podendo atingir até 5 metros de altura. Essa planta é originária de qual país?

- Paraguai

- Índia*

- Uruguai

- Jamaica

A Maconha tem sua origem na Índia. Os primeiros relatos dessa erva no Brasil datam do século XVIII quando era usada para a produção de fibras chamadas de cânhamos. 


\section{0 fruto da maconha é:}

- Amarelo-esverdeado, pequeno, ovalado e contém uma substância ácida, que serve de alimento para algumas espécies de aves.*

- Verde-amarelado, grande, ovalado e contém uma substância ácida, que serve de alimento para algumas espécies de aves.

- Amarelo-esverdeado, pequeno, ovalado e contém uma substância líquida, que serve de alimento para algumas espécies de peixes.

- Verde-amarelado, pequeno, ovalado e contém uma substância ácida, que serve de alimento para algumas espécies de aves.

\section{Qual foi o primeiro país do mundo a legalizar a maconha?}

- México

- E.U.A

- Índia

- Uruguai*

O presidente do Uruguai, José Mujica, assinou oficialmente uma proposta para legalizar a maconha em todo o país, tornando-a de fato uma lei e sendo o primeiro país do mundo a fazê-lo desde que a proibição começou há décadas atrás.

\section{Qual o nome do presidente do primeiro país a legalizar a maconha?}

- José Serra

- Hugo Chaves

- José Mujica*

- Vladimir Putin

José Mujica, presidente do Uruguai, assinou oficialmente uma proposta para legalizar a maconha em todo o país.

\section{Alguns países já permitem produção da erva(maconha). São Exemplos:}

- Canadá, alguns estados dos E.U.A e Brasil

- Holanda, E.U.A e alguns estados do Japão

- Espanha, Paraguai e Holanda

- Holanda, Espanha e alguns estados dos E.U.A*

Holanda, Espanha e alguns estados dos Estados Unidos permitem a produção, o cultivo em clubes ou o consumo com restrições de maconha. 
71.No Brasil, a maconha é um assunto ainda polêmico, no entanto, sobre essa erva nesse país é correto afirmar que:

- É vista como uma droga sem finalidade causadora de doenças e altamente prejudicial, sem benefícios.

- É proibido comentários a respeito dessa erva.

- A maconha é uma droga ilegal. No entanto, a utilização terapêutica foi permitida a partir de 1993, de acordo com o Ministério da Saúde.

- Cerca de 1,5 milhão consomem maconha todos os dias. Senado Federal vai discutir a possibilidade de protocolar um projeto de lei que regulamente o uso recreativo, medicinal e industrial da maconha.*

Em resposta a uma proposta de iniciativa popular apresentada por meio de seu site na internet, o Senado Federal vai discutir a possibilidade de protocolar um projeto de lei que regulamente o uso recreativo, medicinal e industrial da maconha no Brasil.

72.Qual foi o primeiro país no mundo a permitir legalmente o uso da maconha para fins medicinais?

- Canadá*

- Portugal

- Grécia

- Uruguai

Canadá foi o primeiro país no mundo a permitir legalmente o uso da maconha para fins medicinais. Os canadenses podem cultivar maconha e consumir a erva se tiverem receita médica e um documento de autorização emitido pelo governo.

\section{São considerados alguns benefícios do uso de maconha:}

- É uma planta que contém uma substância ácida.

- É uma erva que tem origem na Índia.

- Pode ser usada para fins medicinais, combatendo câncer, inclusive.*

- É usada na gastronomia.

Um novo estudo publicado na mais recente edição da revista Phytomedicine, e publicado on-line pelo Instituto Nacional de Saúde do EUA, descobriu que os medicamentos a base de Cannabis podem fornecer uma cura para o câncer de cólon. 


\section{Em relação a plantação de maconha é correto afirmar que:}

- São plantas de grande porte cultivada principalmente em clima frio.

- Pode atingir até cinco metros de altura, sem frutos

- Planta herbácea de clima quente e úmido, a maconha (Cannabis sativa) pertence à família Moraceae e pode atingir até 5 metros de altura. Possui folhas digitadas e flores pequenas, amarelas e sem perfume.*

- São consideradas plantas de grande porte, pertence à família Moraceae e pode atingir até 22,5 metros de altura.

Planta herbácea de clima quente e úmido, originária da Índia, a maconha (Cannabis sativa) pertence à família Moraceae e pode atingir até 5 metros de altura. Possui folhas digitadas e flores pequenas, amarelas e sem perfume.

76. Verdadeiro ou falso: a cocaína purificada foi um ingrediente no início das formulações da Coca-Cola.

- Falso

- Verdadeira*

No início dos anos 1900, a cocaína purificada era o principal ingrediente de vários tônicos medicinais e elixires - e, sim, foi um ingrediente da Coca-Cola. No entanto, mais tarde pesquisas mostraram que a cocaína era uma substância altamente viciante. Por isso, esse ingrediente não existe mais na Coca-Cola.

78."Speedball" é um termo normalmente utilizado para a combinação de quais drogas?

- Cocaína e metanfetamina

- Ecstasy e heroína

- Cocaína e heroína*

- Ecstasy e metanfetamina

Como a cocaína atua como um estimulante e a heroína atua como um depressor, combiná-las busca reduzir os efeitos negativos de cada uma - ansiedade, hipertensão e palpitações (dos estimulantes) e sedação e sonolência (dos depressivos). Essa perigosa combinação é conhecida como "speedball." 
80.Qual das seguintes não é uma droga opioide?

- Vicodin

- Oxicodona

- Codeína

- Valium*

Valium - um sedativo usado para tratar ansiedade, espasmos musculares e convulsões

— é uma benzodiazepina, não um opioide

\section{Como a psilocibina é mais comumente conhecida?}

- Cogumelos alucinógenos*

- Peiote

- Sálvia

- PCP

Psilocibina = um composto psicodélico mais conhecido como $\sim$ cogumelos alucinógenos . É extraída de certos tipos de cogumelos, pode ser seca ou fresca e pode ser comida crua ou adicionada em um chá para efeitos alucinógenos.

\section{De qual das seguintes maneiras a cocaína NÃO PODE ser administrada?}

Oral

Intranasal

Via intravenosa

Todas as formas acima*

\section{Verdadeiro ou falso: a maconha é a droga ilícita mais utilizada nos EUA?}

- Verdadeiro*

- Falso

De acordo com a Pesquisa Nacional de 2014 sobre Uso de Drogas e Saúde dos EUA, a maconha é a droga ilícita mais utilizada. E, aliás, o "uso de drogas ilícitas" é definido pelo Departamento de Saúde e Serviços Humanos dos Estados Unidos como o abuso de drogas ilegais ou o uso indevido de medicamentos de prescrição ou de substâncias de uso doméstico. 
84.Qual das seguintes afirmações sobre o ecstasy é falsa?

- Diminui a temperatura corporal*

- Foram feitas pesquisas sobre seu potencial eficácia no tratamento do transtorno de estresse pós-traumático

- Tem propriedades tanto estimulantes quanto psicodélicas

- Não é incomum que os comprimidos de ecstasy contenham aditivos, como cocaína e metanfetamina

85.Qual dos seguintes é um exemplo das diferenças entre a metanfetamina e a cocaína?

- A metanfetamina é ópio, a cocaína é um estimulante

- A metanfetamina é feita pelo homem, enquanto a cocaína é derivada de plantas*

- A metanfetamina é fumada, enquanto a cocaína pode ser administrada de várias maneiras

- A metanfetamina produz um efeito mais curto do que a cocaína

86.Verdadeiro ou falso: a sálvia é uma cepa de maconha?

- Verdadeiro

- Falso *

Não, são duas plantas completamente diferentes. A sálvia é uma droga dissociativa da família do hortelã, nativa do sul do México e da América do Sul. A maconha, por outro lado, é feita da planta do cânhamo, Cannabis sativa.

98.Abuso de álcool, nicotina e substâncias ilegais custa muito dinheiro. 0 custo anual de seu impacto médico, econômico, penal e social combinado é estimado em:

- 500 milhões de dólares

- 1 bilhão de dólares

- 100 bilhões de dólares

- 500 bilhões de dólares*

O Instituto Nacional sobre Abuso de Drogas (NIDA) diz que meio trilhão de dólares é gastos nessas áreas relacionadas a álcool e drogas. 
99.Todos os anos, o abuso de drogas ilícitas e álcool contribui para a morte de quantos brasileiros?

- 1000

- 5000

- $8000^{*}$

- 10000

O Datasus informou que o álcool tirou a vida de $84,9 \%$ do total de mortes, estando em segundo lugar o fumo com 11,3\%. Vale lembrar que este número se refere apenas a uma parcela dos óbitos em consequências do uso de drogas no Brasil, pois mostra aqueles causados diretamente pelo consumo de drogas.

\section{0 consumo moderado de álcool para um homem adulto é considerado quanto} por dia?

- 0 equivalente a 6 latas de cerveja

- O equivalente a duas bebidas alcoólicas de $120 \mathrm{~mL}^{*}$

- $\quad 0$ equivalente a dois cálices de vinho de $150 \mathrm{~mL}$

- O equivalente a 10 latas de cerveja

A Sociedade Brasileira de Cardiologia afirma que o consumo moderado de álcool é de até dois drinques por dia ( $30 \mathrm{~g}$ de etanol) para homens e até um drinque por dia para as mulheres. Isso se refere à quantidade consumida em um único dia. Não é uma média ao longo de vários dias. Na verdade, certas pessoas não devem consumir álcool. Estes incluem os menores de idade, mulheres grávidas ou que possam engravidar, pessoas que usam certos medicamentos e pessoas com certas condições de saúde. Aqueles com história de alcoolismo ou dependência de outra substância deve evitar o álcool. Verifique com seu médico se você acha que pode estar em um grupo de risco. 


\section{Jogo \\ 1 Sou Dependente Químico? \\ Valdiana Gomes Cavalcante}

\section{OBJETIVO}

Analisar as diversas formas de ajudar uma pessoa dependente química, mostrando que um dependente pode possuir diversos perfis, não sendo somente alguém que mora na periferia e possui baixa-renda.

\section{№ DE JOGADORES: 5 a 8}

\section{INSTRUÇÕES:}

- Ao começar o jogo, os jogadores pegam uma carta em um baralho inicial (existem várias cartas com o nome "ajudante" e apenas uma carta com o nome "dependente químico", ou seja, vai existir apenas um jogador dependente e todos os outros terão como objetivo ajudar a libertar o dependente e buscar propostas de melhoria de vida);
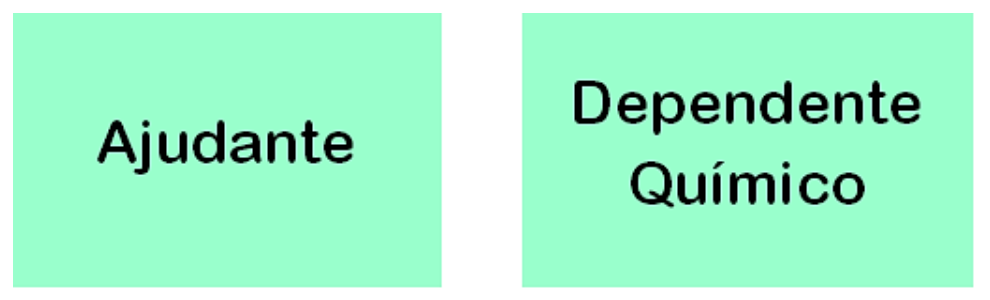

- Depois de definido quem será o dependente, tal jogador irá escolher uma carta de outro baralho que contêm 5 cartas, cada uma haverá um perfil diferente de dependente químico, mostrando que a dependência química afeta pessoas de diversas classes sociais e idades. 


\begin{tabular}{|c|c|c|}
\hline $\begin{array}{l}\text { Nome: José Carlos Castro } \\
\text { Idade: } 17 \text { anos } \\
\text { Dependência Quimica: } \\
\text { Cocaina }\end{array}$ & $\begin{array}{l}\text { Nome: Bruna Ferreira } \\
\text { Lima } \\
\text { Idade: } 45 \text { anos } \\
\text { Dependência Quimica: }\end{array}$ & $\begin{array}{l}\text { Nome: Estevão Cardoso } \\
\text { Idade: } 63 \text { anos } \\
\text { Dependência Química: } \\
\text { Maconha }\end{array}$ \\
\hline $\begin{array}{l}\text { Informações: Mora com } \\
\text { os pais em um } \\
\text { apartamento de luxo na } \\
\text { cidade de Fortaleza - CE } \\
\text { e estuda em um dos } \\
\text { melhores colégios } \\
\text { particulares de Fortaleza. } \\
\text { Está prestes a prestar o }\end{array}$ & $\begin{array}{l}\text { Informações: Mora na } \\
\text { periferia de Fortaleza e } \\
\text { trabalha em uma } \\
\text { empresa conceituada } \\
\text { em sua cidade. Possui } \\
\text { apenas o Fundamental II }\end{array}$ & $\begin{array}{l}\text { Informações: Mora em } \\
\text { umaridade } \\
\text { metropolitana r de } \\
\text { Fortaleza e é aposentado } \\
\text { como trabalhador rural. }\end{array}$ \\
\hline Ajude! & njuce: & \\
\hline $\begin{array}{l}\text { Perfil } \\
\text { Nome: Geovana Matias } \\
\text { Idade: } 32 \text { anos } \\
\text { Dependência Química: } \\
\text { Alcoolismo }\end{array}$ & $\begin{array}{l}\text { Nome: João Pedro de } \\
\text { Caldas } \\
\text { Idade: } 26 \text { anos } \\
\text { Dependência Quimica: }\end{array}$ & $\begin{array}{l}\text { Nome: Regina de Melo } \\
\text { Idade: } 23 \text { anos } \\
\text { Dependência Química: } \\
\text { Cocaina }\end{array}$ \\
\hline $\begin{array}{l}\text { Informações: Mora em } \\
\text { um condomínio de Luxo } \\
\text { em Fortaleza e é diretora } \\
\text { de uma marca de moda } \\
\text { nacional. }\end{array}$ & $\begin{array}{l}\text { Informações: Mora na } \\
\text { periferia de Fortaleza, } \\
\text { possui } 2 \text { filhos e é } \\
\text { comerciante. }\end{array}$ & $\begin{array}{l}\text { Informações: Mora na } \\
\text { zona metropolitana e } \\
\text { estuda medicina em uma } \\
\text { Universidade de Fortaleza. } \\
\text { Ė autônoma e possui uma } \\
\text { filha. }\end{array}$ \\
\hline Ajude! & Ajude! & Ajude! \\
\hline
\end{tabular}

- Definido o Perfil do jogador personagem dependente, inicia-se uma rodada onde estarão presentes 2 caixas. Uma com "pontos negativos" e outra com "pontos positivos", que apresentarão, respectivamente, algo que pode influenciar o vício e algo de positivo que ajude a melhorar a vida e a combater o vício. Nesta rodada só irão participar os jogadores ajudantes; o jogador dependente irá apenas participar como ouvinte.

- Os jogadores ajudantes começarão o jogo em sentido horário, jogando dois dados. Caso a soma dos dados dê como resultado número par, o jogador retirará uma ficha da caixa dos "pontos positivos", caso o resultado seja número ímpar, terá de retirar uma ficha da caixa dos "pontos negativos". A rodada terminará quando todos os jogadores ajudantes retirarem um papel de uma das caixas apresentadas. 


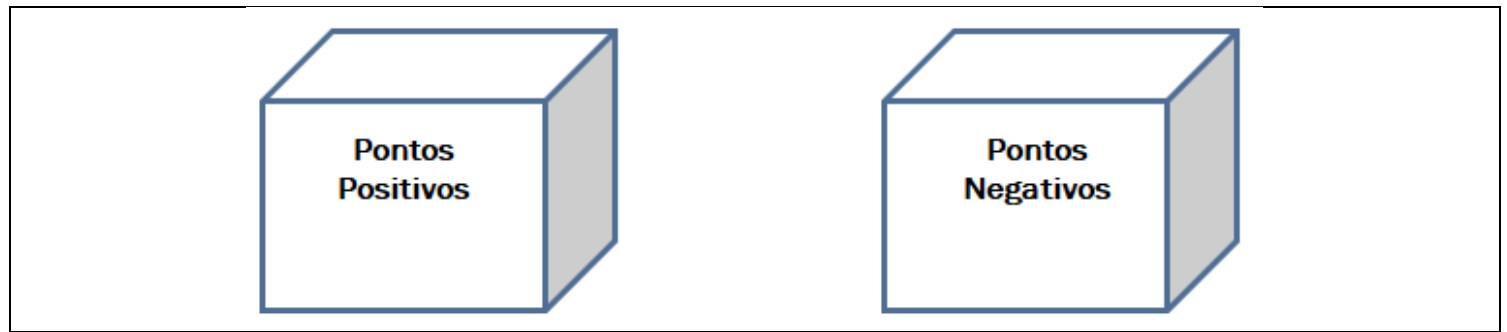

Ao final da rodada, já saberá qual o perfil do usuário e quais pontos negativos e positivos foram determinantes para o combate ou não do vício. Então, os jogadores ajudantes deverão em grupo descobrir melhor forma de ajudar o dependente. 0 jogo finaliza quando todos entram em acordo a respeito de como ajudar e retirar o dependente do determinado vício, sendo determinantes para a decisão as fixas retiradas da caixa.

\section{Pontos positivos:}

- Ganhou uma promoção na empresa em que trabalha.

- Começou a praticar um esporte.

- Trocou os momentos de ociosidade pela leitura.

- Conseguiu comprar uma nova casa em outro bairro.

- Recebeu uma proposta de emprego em outro Estado.

- Fez boas amizades;

- Conseguiu uma vaga em um centro de reabilitação;

- Família uniu-se para pagar dívida com os traficantes de drogas.

\section{Pontos negativos:}

- Foi demitido do emprego;

- Recebeu um diagnóstico de uma doença rara;

- Está sofrendo de depressão;

- Alguns amigos publicaram falsas notícias suas em uma rede social;

- O filho reprovou no colégio;

- A mulher pediu divórcio;

- Foi jubilado da faculdade em que estudava;

- Brigas familiares. 


\section{Jogo \\ 4 De cara com as drogas \\ Sarah Geysa de Oliveira Ribeiro; Dayanne Cipriano Costa da Silva; Alvaro Ventorini Vasconcelos; Geovana Costa Aguiar}

\section{INTRODUÇÃO}

As drogas são de longe um dos problemas de saúde pública mais decorrentes em nossa sociedade, em um mundo de euforia e constantes problemas as drogas se manifestam como amenizador ou válvula de escape, um caminho tentador e as vezes sem volta. Existem diversos tipos de drogas classificadas em licitas e ilícitas, cada uma com sua peculiaridade e forma de ação. Com o intuito não só de alertar aos jogadores sobre o risco das drogas mais também mostra o quão o organismo sofrer pela presença destas, o jogo cara-a-cara traz de forma didática curiosidades, fatos e consequências do uso das drogas, de modo que se possa de forma científica e eficaz conscientizar ao aluno o quão é importante não optar por este caminho.

\section{MATERIAIS E MÉTODOS}

Através de características e mecanismo de ação no corpo, são feitas perguntas executadas por ambos os jogadores onde estes procuram saber qual droga misteriosa é o do seu adversário. Com o desenvolvimento do jogo, procura-se alertar sobre as drogas tanto lícitas como ilícitas. Apesar de todas apresentarem efeitos devastadores no organismo, cada uma possui sua peculiaridade e velocidade de ação. Juntamente com o tabuleiro, que pode ser confeccionado a partir de uma caixa de papelão com palitos de churrasco, anexou-se um conjunto de cartas onde se tem características e efeitos das drogas no organismo, este não apenas serve como auxílio para desenvolvimento do jogo, mas também como fonte de conhecimento para os jogadores.

NÚMERO DE JOGADORES: Dois no máximo por rodada.

OBJETIVO: tentar adivinhar a droga misteriosa.

\section{REGRAS:}

1. Embaralhe as cartas Misteriosas;

2. Pegue uma carta e guarde-a sem deixar o outro jogador ver. Depois, peça para seu adversário fazer o mesmo;

3. Escolha um dos lados do tabuleiro. Os dois tabuleiros do jogo contêm os mesmos personagens, que devem também estar alinhados na mesma ordem para ambos os jogadores;

4. Erga todas as molduras com as fotos para que você possa ver todas as opções; 
5. Sente de frente para o oponente para que ele não consiga ver os traços da sua carta. Tentar adivinhar esse nome é o objetivo do jogo, portanto cuidado com a carta;

6. Cada jogador tem direito a uma pergunta por rodada;

7. Abaixe as molduras que não descrevam a droga misteriosa;

8. Quando achar que sabe quem é a droga misteriosa, tente adivinhá-la. Se o seu palpite estiver certo ou se o seu adversário errar, você ganha o jogo. Quando alguém tenta adivinhar a droga misteriosa e erra, o outro jogador deve dizer a resposta certa.

- Cartas do jogo

\begin{tabular}{|l|c|c|}
\hline Cannabis & Cocaína & Ecstasy \\
\hline Heroína & LSD & Metanfetamina \\
\hline Anticolinérgicos & Tabaco & Cafeína \\
\hline
\end{tabular}

\begin{tabular}{|c|c|c|}
\cline { 3 - 3 } Opioides & & Barbitúrico \\
\hline $\begin{array}{c}\text { Solventes } \\
\text { ou } \\
\text { Inalantes }\end{array}$ & Benzodiazepínicos & Anfetaminas \\
\hline Loló & & Crack \\
\hline
\end{tabular}

- Cartas de apoio
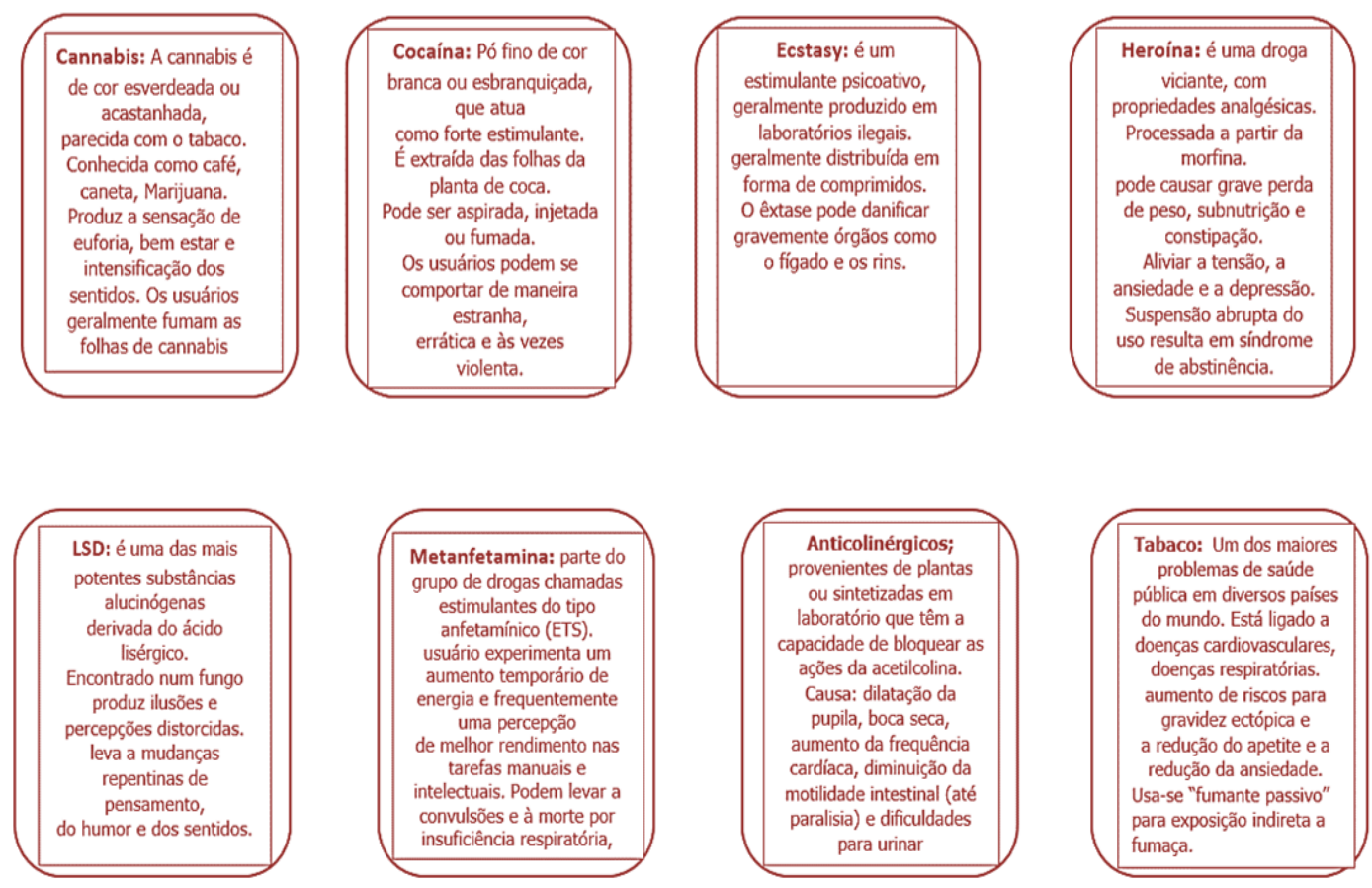


\section{GUIA DE CARACTERISTICAS DAS DROGAS PARA O JOGO CARA A CARA}
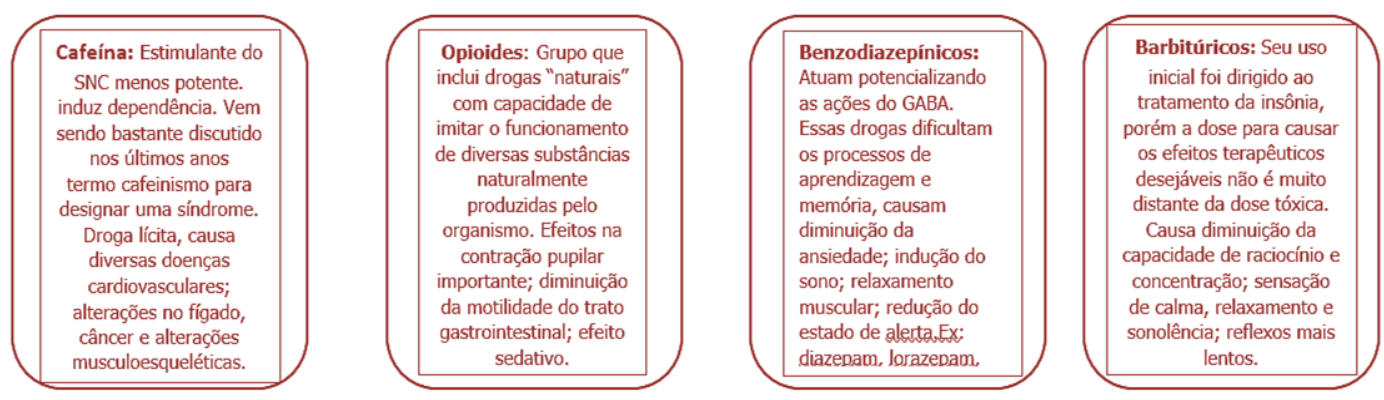

Solventes ou inalantes:

Os efeitos têm início

rapidamente após a

inalação, 0 uso crônico

dessas substâncias pode

levar à destruição dos

neurônios.

São incluídas neste grupo

as drogas capazes de

aumentar a atividade de

determinados sistemas neuronais.
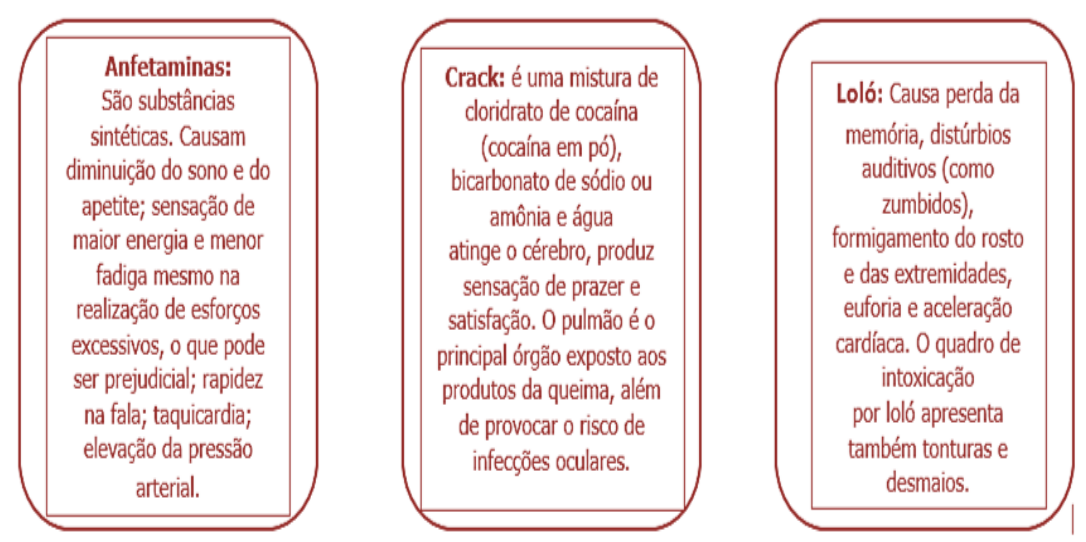


\section{REFERÊNCIAS}

[1] ALMEIDA, N.P. Educação lúdica: Técnicas e jogos pedagógicos. Edições Loyola, São Paulo, Brasil. 1974. 11a Edição, 2003. www.brasilescola.com/drogas

[2] BANANA QUÂNTICA. A do jogo "Cara a cara". Disponível em <https://www.bananaquantica.com.br/regra-do-jogo-cara-a-cara/>. Acesso em 17 de Mar. de 2020.

[3] BAYNES, J. W.; DOMINICZAK, M. H. Bioquímica Médica. 3a ed. Rio de Janeiro: Elsevier, 2010.653p.

[4] BENEDETTI FILHO, E.; BENEDETTI, L. P. S. Emprego de atividades lúdicas no Ensino de Química. Gráfica Editora Cidade / Sorocaba - SP, 2015. 96p.

[5] BRANDÃo, M. L. As bases biológicas do comportamento - Introdução à neurociência. São Paulo: EPU, 2004. 223p.

[6] BRASIL. Ministério da Educação. Instituto Nacional de Estudos e Pesquisas Educacionais Anísio Teixeira. Censo da Educação Superior 2010: Divulgação dos principais resultados do Censo de Educação Superior 2010. Brasília - DF, INEP; 2011.

[7] BRASIL.Presidência da República. Secretaria Nacional de Políticas sobre Drogas. I Levantamento Nacional sobre o uso de álcool, tabaco e outras drogas entre universitários das 27 capitais brasileiras. Brasília - DF, SENAD; 2010.

[8] BRASIL. Ministério da Educação (MEC). Secretaria da Educação Média e Tecnológica (Semtec). Orientações Curriculares Nacionais para o Ensino Médio. Brasília: MEC/Semtec, 2006.

[9] CAVALCANTI, E. L. D.; DEUS, T. C. e SOARES, M. H. F. B. Perfil químico: um jogo didático para promover a interação e o conhecimento. In: Anais da 30ª Reunião Anual da Sociedade Brasileira de Química, 2007.

[10] CUNHA, A. P. ;LIBERATO, M. C. T. C. ; VERAS, A. O. M. Aprenda Química Brincando / SEDUC. Fortaleza: SEDUC, 2006. 88p.

[11] CUNHA, M. B. Jogos de Química: Desenvolvendo habilidades e socializando o grupo. ENEQ. 2004.

FAI, Portal PIBID Drogas: Classificação e efeitos no organismo. Disponível em: <http://www.fai.com.br/portal/pibid/adm/atividades_anexo/74df176f30bca479a211a 121bfbc6a40.pdf. > Acesso em 17 de Mar. de 2020.

[12] FRANCISCHI, J. N. A Farmacologia em Nossa Vida. Belo Horizonte: Editora UFMG, 2005. 137p. 
[13] FRIEDMANN, Adriana. Brincar: crescer e aprender: o regate do jogoinfantil. São Paulo: Moderna, 1996.

[14] IVERSEN, L. L.Drogas - Porto Alegre, RS: L \& PM, 2012. 144p.

[15] LIBERATO, M. C. T. C.Bioquímica das Drogas - Fortaleza: UECE: 2013. 126p.

[16] LIMA, M.A.A. A utilização de jogos didáticos como ferramenta no ensino de funções orgânicas. CBQ 2009.

[17] LONGENECKER, G. L. Como Agem as Drogas. Editora Quark do Brasil Ltda., 1998. 131p.

[18] NOTO, A. R.; GALDURóZ, J. C. F.; NAPPO, S. A.; FONSECA, A. M.; CARLINI, C. M. A.; MOURA, Y. G.; CARLINI, E. A. Levantamento Nacional sobre o Uso de Drogas entre Crianças e Adolescentes em Situação de Rua nas 27 Capitais Brasileiras. Centro brasileiro de informações sobre drogas psicotrópicas (CEBRID). Universidade Federal de São Paulo. Escola Paulista de Medicina.

[19] Departamento de Psicobiologia. 2003.

[20] PEIXOTO, C. A. dos S.; JESUS, J. de; SANTOS, L. S. B.; GUZZI FILHO, N. J.; BELLO, M. E. do R. B. ; PRUDÊNCIO, C. A. V. Elementos da Situação para a formação de Professores da Educação Técnica. XI Encontro Nacional de Pesquisa em Educação em Ciências - XI ENPEC - Universidade Federal de Santa Catarina, Florianópolis, SC - 3 a 6 de julho de 2017

[21] PEUKER, A.C.; FOGAÇA, J.; BIZARRO, L.- Expectativas e beber problemáticoentre universitários. Psicologia: Teoria e Pesquisa, n. 22, p. 193 - 200, 2006.

[22] RETOND0, C. G.; FARIA, P.Química das Sensações. 3ª Ed. Campinas, SP: Editora Átomo, 2009. 266p.

[23] RIBEIRO, T. W.; PERGHER, N. K.; TOROSSIAN, S. D. Drogas e adolescência: uma análise da ideologia presente na mídia escrita destinada ao grande público. Revista de laUniversidad Federal do Rio Grande do Sul/Puerto Alegre, Brasil / ISSN 0102-7972.

[24] SACKHEIM, G. I. ; LEHMAN, D. D.Química e Bioquímica para CiênciasBiomédicas. 8ª Ed. Editora Manole, Ltda. SP - Brasil, 2001. 644p.

[25] SANTANA, M.A.A. Jogos didáticos: Uma ferramenta útil nas aulas de Química. CBQ 2010.

[26] SENNA, A. Legislação Brasileira do Ensino Secundário de 1901 a 1939. Rio de Janeiro: Edição da Livraria Central, 1939. 
[27] SILVA, M. M. O., et al. Apresentado na 35a Reunião Anual da Sociedade Brasileira de Química, emÁguas de Lindóia, 28 a 31 de maio de 2012.

[28] SMITH, C.; MARKS, A. D.; LIEBERMAN, M. Bioquímica Médica Básica de Marks - Uma abordagem Clínica. 2ª ed. Porto Alegre: Artmed, 2007. 992p.

[29] SOARES, M. H. F. B. Jogos e Atividades lúdicas para o ensino de Química. 2a edição - Goiânia: Kelps, 2015. 198p.

[30] UNITED NATIONS OFFICE ON DRUGS AND CRIME (UNODC). Global study on homicide: trends, context, data. Vienna (AT): UNODC; 2011. Disponível em: http://www.unodc.org/documents /data-and-analysis/statistics/Homicide/ Globa_study_on_homicide_2011_web.pdf. Acesso: 19 de ago. de 2017.

[31] VIEIRA, P. C.; AERTS, D. R. G. C.; FREDDO, S. L.; BITTENCOURT, A.; MONTEIRO, L. Uso de álcool, tabaco e outras drogas por adolescentes escolares em município do Sul do Brasil. Cad. Saúde Pública, Rio de Janeiro, 24(11):2487-2498, nov, 2008.

[32] VYGOTSKI, L.S. A formação social da mente. São Paulo: Martins Fontes, 1996.

[33] ZANON, D. A. V.; GUERREIRO, M. A. S.; OLIVEIRA, R. C. Jogo didático Ludo Químico para o ensino de nomenclatura dos compostos orgânicos: projeto, produção, aplicação e avaliação. Ciências \& Cognição (UFRJ), v. 13, p. 72-81, 2008. 


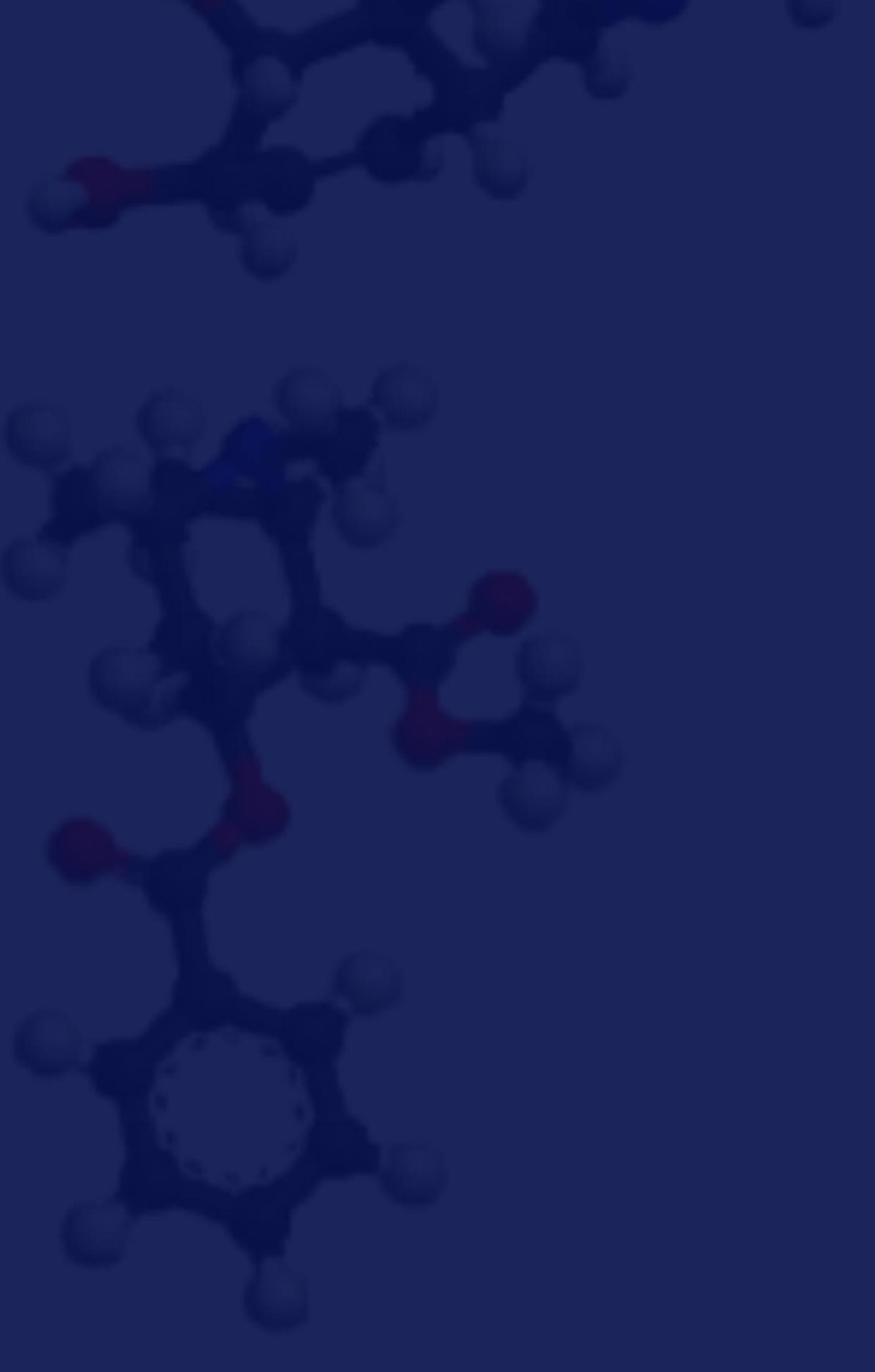

